Portland State University

PDXScholar

\title{
International Education in the Public Community Colleges of Oregon and Washington
}

Stephan Ernest Cragg

Portland State University

Follow this and additional works at: https://pdxscholar.library.pdx.edu/open_access_etds

Part of the Higher Education Administration Commons Let us know how access to this document benefits you.

\section{Recommended Citation}

Cragg, Stephan Ernest, "International Education in the Public Community Colleges of Oregon and Washington" (1992). Dissertations and Theses. Paper 1290.

https://doi.org/10.15760/etd.1289

This Dissertation is brought to you for free and open access. It has been accepted for inclusion in Dissertations and Theses by an authorized administrator of PDXScholar. Please contact us if we can make this document more accessible: pdxscholar@pdx.edu. 
INTERNATIONAL EDUCATION

IN THE PUBLIC COMMUNITY COLLEGES OF

OREGON AND WASHINGTON

by

STEPHAN ERNEST CRAGG

A dissertation submitted in partial fulfillment of the requirements for the degree of

DOCTOR OF EDUCATION in

EDUCATIONAL LEADERSHIP: POSTSECONDARY EDUCATION

Portland State University

- 1992 
TO THE OFFICE OF GRADUATE STUDIES:

The members of the Committee approve the dissertation

of Stephan Ernest Cragg presented January 30, 1992 .

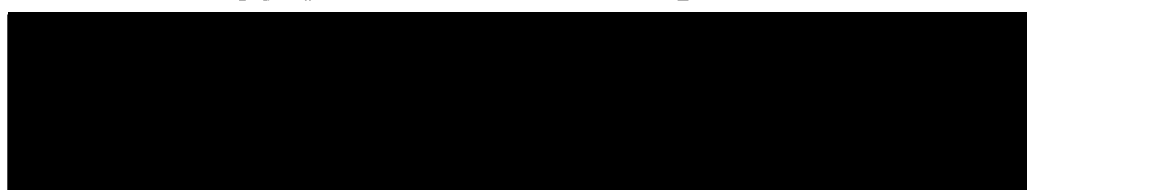

Mary K. Kinnick, Chairperson

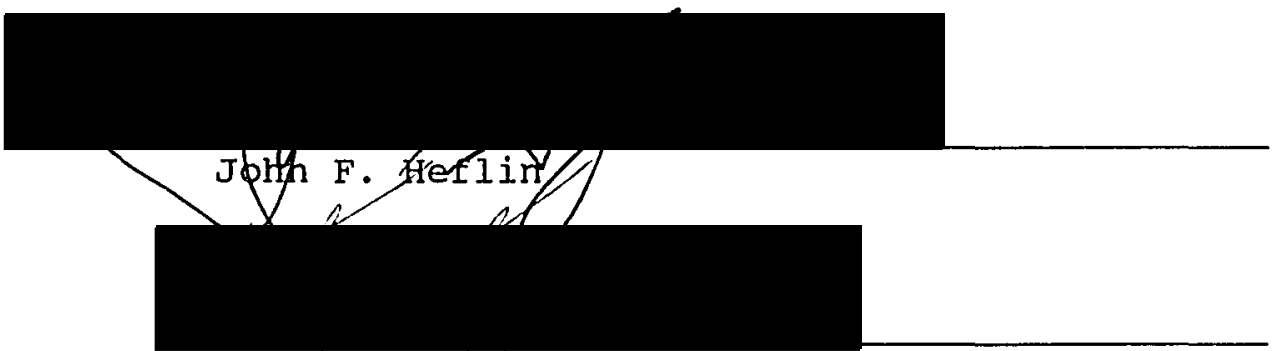

Kennéth Kempner

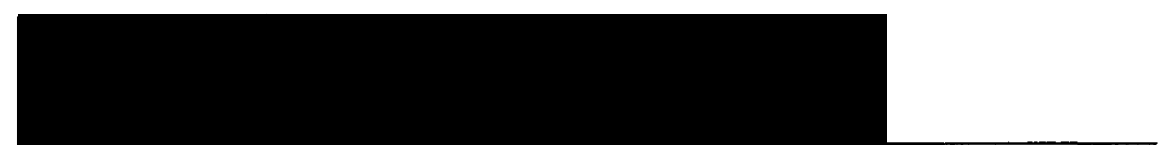

Eouglas L. Robertson

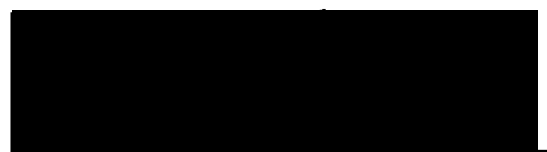

Mel Gurtov

APPROVED :

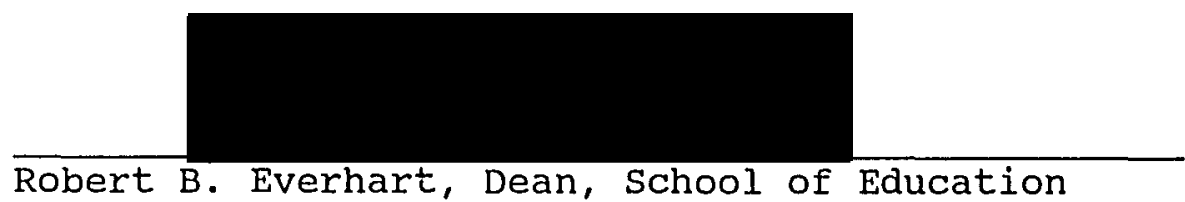

Robert B. Everhart, Dean, School of Education

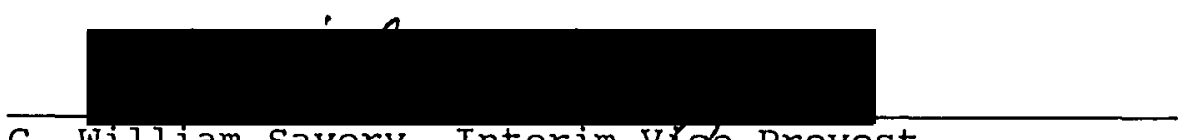

C. William Savery, Interim Vlde provost

for Graduate studies and Research 


\section{ACKNOWLEDGEMENTS}

There are a great many people that need to be acknowledged as this dissertation and degree reach culmination for me. When I first started this quest for the "next degree" in 1979, Dr. Paul Preuss was the one part-time (and only) professor teaching classes in the then new and undefined community college education program at Portland state University. So, I thank him for getting me started. Several classes, several years, and several program changes later, Dr. Ken Kempner came into my life as my second advisor and professor. I thank him for keeping me going in this program. I thank him, too, for staying with me and serving on my committee even after he moved to the University of oregon. His commitment to people and ideas is truly inspirational.

Several more classes, several more years, and many thousands of commuter miles later, Dr. Mary Kinnick came into my life as my third, and last, advisor and professor. With her unfailing support, encouragement, and, occasional brow-beating, this dissertation is now complete. Without her intellect, constructive viewpoints, and friendship, I'm absolutely sure this project would not have come to fruition with its character and depth of understanding toward the 
subject matter as it possesses. She provided me with so many in-sights and perceptions about the fields of research and international education that this product would not have been nearly as rich as it is. I thank her for helping me get it finished.

I wish to thank all the members of my committee for taking the time and effort to contribute their expertise to this endeavor. I have known Dr. John F. Heflin throughout my long stay at Portland State University, so I want to extend a special thanks to him for all those times we just sat and chatted about life.

I wish to thank all those individuals who, in one way or another, contributed generously to the substance of this dissertation with their time, frankness and openness about their campus programs. Their in-sights and responses really made a difference.

As the final product came into focus, I thought about the many contributions of those writers and thinkers that have influenced me and my thinking in my professional career and whose images shadow these pages. There are many, of course, but political scientists James Downton, Gabriel Almond, and Richard Fagan were, perhaps, among the greatest as each of them, unknowingly, helped shape my views and thought processes through their combined thoughts on "political systems analysis." 
No acknowledgement would be complete without thanking all the people in my private life who have had to put up with me and my long-term quest for completing this "project." No one who has known me for the past decade has escaped my oft-repeated references to "my paper" or "my book" as a rationale for either doing something or not doing it. My mother heard it. My children, Michael, Vicki, and Pahla, especially, heard it. My work colleagues heard it. And, certainly, my wife, Dolores, heard it. She married me in spite of it. To her, I give a very special thanks, as she not only heard the words, she kept me company through the many long hours of composing, writing, typing, and driving to and from the community colleges studied in this dissertation. She was, and is, a tower of strength in my life that goes way beyond the study of international education programs.

My secretary, Mary Rose Jansen, and the PSU secretaries, Melinda and Patti, were always there when I needed them. To everyone else who helped me in any way at all, a big thank you! 
TABLE OF CONTENTS

PAGE

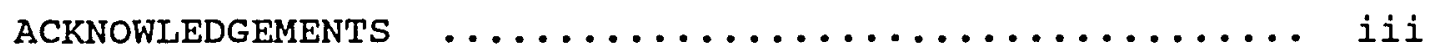

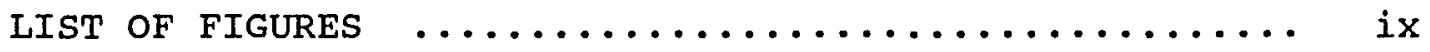

CHAPTER

I INTRODUCTION TO INTERNATIONAL EDUCATION $\ldots . .1$

Statement of the Problem $\ldots \ldots \ldots \ldots \ldots .6$

Significance of the Research $\ldots \ldots \ldots 11$

Purposes of the study $\ldots \ldots \ldots \ldots \ldots \ldots$

The Research Questions $\ldots \ldots \ldots \ldots \ldots 17$

study Propositions $\ldots \ldots \ldots \ldots \ldots \ldots \ldots$

Stages of the Dissertation $\ldots \ldots \ldots \ldots 18$

Limitations $\ldots \ldots \ldots \ldots \ldots \ldots \ldots \ldots \ldots$

II REVIEW OF THE LITERATURE $\ldots \ldots \ldots \ldots \ldots \ldots \ldots . \ldots 22$

A New Taxonomy of International

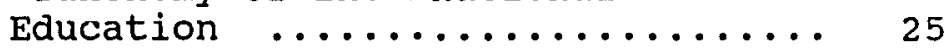

Recruitment of International students . 26

Foreign Born Faculty $\ldots \ldots \ldots \ldots \ldots \ldots 28$

Non-Us Curriculum $\ldots \ldots \ldots \ldots \ldots \ldots . \ldots . \ldots 29$

Internationalizing the curriculum $\ldots \ldots \quad 33$

International Trade and Business

Education $\ldots \ldots \ldots \ldots \ldots \ldots \ldots . \ldots \ldots$

Sister College Relationships $\ldots \ldots \ldots \ldots 40$ 
vii

Community colleges Abroad ......... 40

Consortia Arrangements ........... 42

Study Abroad Programs ........... 45

Overseas Military Programs ........ 47

Conclusion $\ldots \ldots \ldots \ldots \ldots \ldots \ldots \ldots \ldots \ldots \ldots$

III METHODOLOGY $\ldots \ldots \ldots \ldots \ldots \ldots \ldots \ldots \ldots \ldots \ldots . \ldots . \ldots . \ldots$

The Research Design $\ldots \ldots \ldots \ldots \ldots \ldots$

Study Propositions $\ldots \ldots \ldots \ldots \ldots \ldots \ldots . . \ldots 2$

Populations and subjects $\ldots \ldots \ldots \ldots \ldots$

Instrumentation $\ldots \ldots \ldots \ldots \ldots \ldots \ldots$

Procedures and Analysis $\ldots \ldots \ldots \ldots \ldots . . .56$

Summary $\quad \ldots \ldots \ldots \ldots \ldots \ldots \ldots \ldots \ldots \ldots$

IV SURVEY QUESTIONNAIRE RESULTS $\ldots \ldots \ldots \ldots \ldots \ldots 69$

Purposes of the Survey Questionnaire .. 69

Background $\ldots \ldots \ldots \ldots \ldots \ldots \ldots \ldots \ldots$

The Status of International Education • 74

The Most Active Community Colleges .... 110

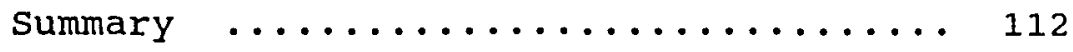

V CASE STUDY RESULTS $\ldots \ldots \ldots \ldots \ldots \ldots \ldots \ldots \ldots$

Purposes of the Case studies ....... 114

Edmonds Community College $\ldots \ldots \ldots \ldots . .115$

Shoreline Community College ....... 137

Mt. Hood Community College ........ 156

Summary $\quad \ldots \ldots \ldots \ldots \ldots \ldots \ldots \ldots \ldots \ldots$ 
VI CONCLUSIONS AND RECOMMENDATIONS $\ldots \ldots \ldots \ldots . . .188$

A Review of the Study Propositions .... 190 Recommendations .................. 204

Suggestions for Future study ....... 210

A SELECTED BIBLIOGRAPHY $\ldots \ldots \ldots \ldots \ldots \ldots \ldots \ldots \ldots \ldots \ldots . \ldots . \ldots 212$ APPENDICES

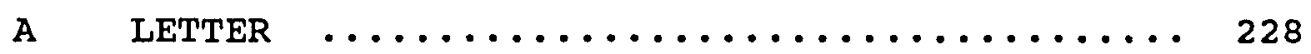

B THE PUBLIC COMMUNITY COLLEGES OF OREGON AND WASHINGTON STATES $\ldots \ldots \ldots \ldots \ldots \ldots \ldots \ldots \ldots . \ldots 230$

C SURVEY QUESTIONNAIRE INSTRUMENT $\ldots \ldots \ldots \ldots .232$

D SURVEY RESULTS $\ldots \ldots \ldots \ldots \ldots \ldots \ldots \ldots \ldots \ldots . \ldots . \ldots 238$

E CONVERTED SURVEY RESULTS .............. 251

F PROTOCOL INSTRUMENT $\ldots \ldots \ldots \ldots \ldots \ldots \ldots \ldots \ldots$ 
IIST OF FIGURES

FIGURE

PAGE

1. Community College Response Rates ......... 71

2. Student Body size By FTE's ............ 72

3. International Education Priority ........ 73

4. International student Enrollments ........ 75

5. International students to FTE's $\ldots \ldots \ldots \ldots . .76$

6. International student Degrees .......... 79

7. Enrolled ESL and ENL Students $\ldots \ldots \ldots \ldots \ldots . \ldots 8$

8. ESL and ENL students to FTE's $\ldots \ldots \ldots \ldots . \ldots . \ldots 8$

9. Percentage of Foreign Born Faculty ....... 85

10. Different Languages and Sections ........ 86

11. Foreign Language Instruction $\ldots \ldots \ldots \ldots . \ldots 8$

12. Non-Us Classes $\ldots \ldots \ldots \ldots \ldots \ldots \ldots \ldots \ldots$

13. Business and Trade Courses ............. 94

14. International Education Classes ......... 95

15. Sister College Relationships ........... 97

16. Faculty International Experiences ........ 105

17. Study Abroad Programs ............... 107

18. Most Active Community Colleges ......... 110

19. Rank and order $\ldots \ldots \ldots \ldots \ldots \ldots \ldots \ldots \ldots \ldots \ldots$ 
AN ABSTRACT OF THE DISSERTATION of stephan Ernest Cragg for the Doctor of Education in Educational Leadership: Postsecondary Education presented January 30, 1992.

Title: International Education in the Public Community Colleges of Oregon and Washington.

APPROVED BY THE MEMBERS OF THE DISSERTATION COMMITTEE:

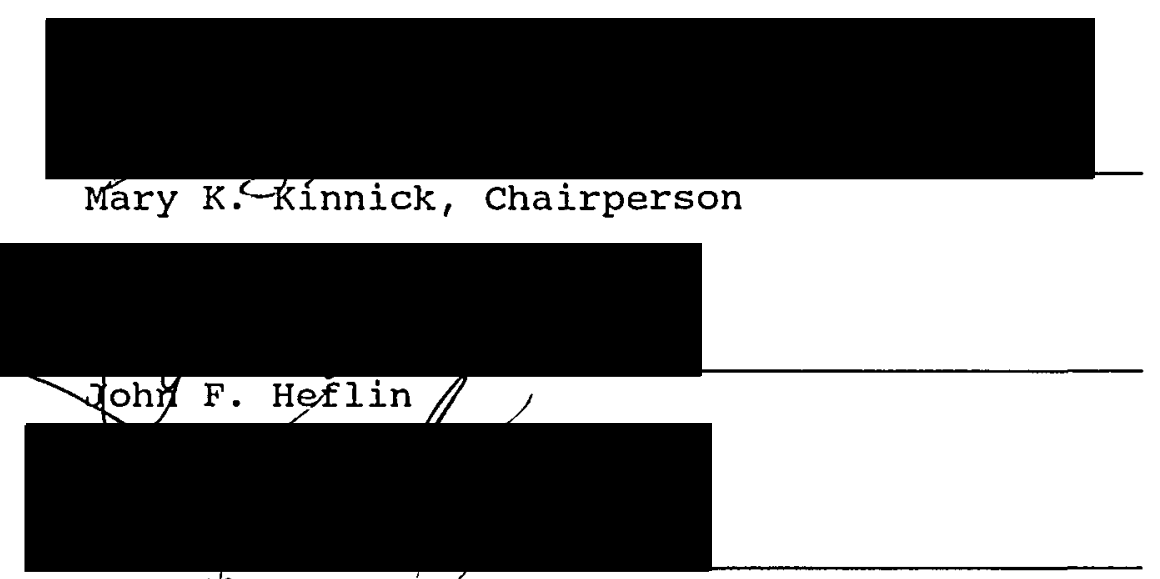

Kenneth Kempner

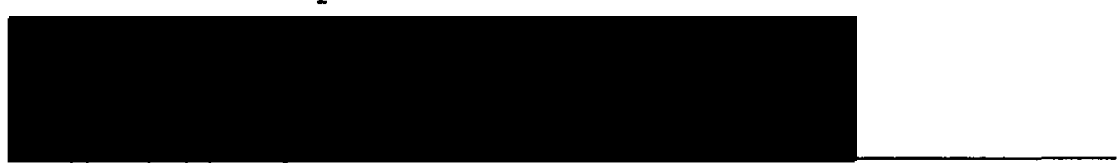

Douglas L. Robertson

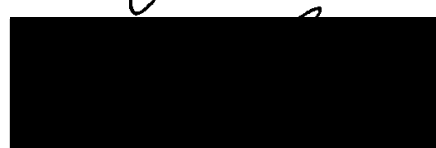

Mel Gurtov

There were at least five purposes in pursuing research on international education in the public community colleges 
of oregon and Washington states. The first purpose was to fully demonstrate a new and original taxonomy of ten elements, or dimensions, found in defining and describing international education. A second purpose was to add to the body of knowledge and research on international education practices at the nation's community colleges through an extensive literature search and original research. A third purpose of the study was to identify and describe the current status of international educational programs and activities of the forty-three public community colleges of the two state region through the use of quantitative data obtained in a survey questionnaire. Another purpose was to identify and describe three case studies of the most highly developed community colleges, at least one from each of the two states, in the arena of international education. A fifth purpose of this study was to provide several conclusions and recommendations to those community college leaders interested in improving upon international education programs and practices.

Two research questions led the investigator to utilize two different research methods: The survey questionnaire and the case study. The research questions were:

1. What is the current status of international education programs among the public community colleges of Oregon and Washington? and

2. How and why did the international education programs and activities evolve and develop at the 
three most highly developed public community colleges of Oregon and Washington?

The first method was used to survey the field of international education and to select three of the most highly developed community colleges in the two state region. The case study method, or the second method, was used to probe deeply into the international education programs and activities of the three most highly developed community colleges in oregon and Washington. The results of the research methodology were reported in two different chapters and provide the findings and recommendations about the field of international education.

The research was also defined by nine propositions suggested at the outset of the study. It was thought that international education programs and activities of oregon and Washington community colleges evolved and developed through: The efforts of strong presidential leadership; large community colleges found in urban areas; the presence of international students; the presence of full-time international education administrators; the presence of international education grants from external funding sources; the presence of a strong global curriculum; the presence of strong foreign language programs; the presence of full-time faculty born in other countries; and, the presence of fulltime faculty who have lived and travelled abroad. The results of the nine study propositions were mixed. 
The research led to twelve specific recommendations for those wanting to either evaluate their existing efforts and for those wanting to enter the very dynamic and exciting field of international education. 
CHAPTER I

INTRODUCTION TO INTERNATIONAL EDUCATION

The sun was shining brightly in the Board of Education Conference Room at 10:00 a.m. on a september morning as a number of college administrators were waiting for the visiting delegation from sok Cho, South Korea, to arrive. The mountain overlooking the college was watching the people, as usual, as it could be seen through the big picture windows at the end of the conference Room. There was an air of anticipation in the room as the American hosts knew little or nothing about their guests.

Quietly, the guests arrived, dressed informally in the anticipation of a day long trip up the Gorge to the beautiful waterfalls and the huge river dam. The college president, speaking through an interpreter, welcomed the guests to the United States and the college. The chief delegate from the city of sok cho, also speaking through the interpreter, accepted the president's warm and affectionate greetings. The college president then introduced his staff, one by one, to his guests. The chief delegate, likewise, introduced his fellow delegates to his hosts. Gifts were 
exchanged by everyone present in the room. The atmosphere remained very formal, yet polite and dignified.

The two groups turned their attention to the prepared agenda, which included presentations by the college staff on specific programs that the president thought his guests might be interested in learning more about. The first presentation was on the new Hospitality and Tourism program. The speaker exhorted his guests to help the college's students learn how to be as gracious as the Korean people are to their visitors. His talk was well received and, obviously, appreciated.

The second speaker told her audience about the activities of the Center for Community and Economic Development. Everyone listened intently how this program assisted the hundreds of students it served grow through the educational classes it offers. The chief of the Korean delegation, Mr. Won-Chin Kim, eschewed his interpreter, and asked in his halting and broken English, "But, how do you educate the spiritual side of your students?"

The speaker was as stunned as anyone in the audience, and the room fell silent. The college contingency began to respond with the titles of courses or the disciplines so familiar to American educators. Finally, the speaker said, "if you mean how do we address the question of God and how He interacts with people, we don't!" 
The answer was probably the one almost everyone in the United states would give, especially if socialized into the American political system, where the doctrine of separation of church and state is a credo nearly everyone lives by. If the group of visitors had been from New York or California or Minnesota or Texas, the question probably would never have surfaced. In fact, the question was so extraordinary that for weeks afterwards the college staff members present talked about the meaning of the question and the cultural context from the which the question arose. There was a profound learning experience derived from the visit by the Korean delegation that bright and sunshiny day in september that went far beyond the exchange of program information sought after by the participants.

$\star * * * \star * * * *$

The chartered bus, small and cramped, took the twelve "estadosunidosenses" from the airport to downtown San Jose, Costa Rica. The air was thick with humidity fxom the afternoon rains, and the diesel smoke, that made your eyes burn, was visible through the night darkness against the light posts along the city streets. The twelve "gringo" community college instructors sat in their seats taking in the sights and sounds of a society and culture for the first time that they had known only through books, films, and lectures. 
In costa Rica on a Us federal government grant, twelve community college instructors were getting a first-hand international experience by visiting another culture. The group would study Spanish every day for forty-four days, listen to guest lecturers on a variety of topics dealing with the development of a nation, and would visit every corner of this tiny Central American democracy. Sandwiched in between two nations, Nicaragua and Panama, that are facing massive internal upheavals with internal warfare and fighting Us policies in the region, costa Rica revealed itself to be the "Switzerland" of Latin America.

Tranquil, stable, and deeply committed to democratic processes, the people of costa Rica are quite different in almost all respects from both the stereotype and the reality of Latin America. More racially homogeneous with a much higher living standard than its neighbors, Costa Rica stands as a model of development, including massive economic problems not easily resolved by a nation dependent upon the "Colossus of the North."

The group of community college instructors would eventually record their impressions of this central American nation in different ways, each having an impact on their teaching and each having an impact on the quality of life on their campuses. 


\begin{abstract}
$* * * * * * * * *$
It took about three days of work to put together all the connections for the appearance of one of the soviet Union's best known historians to speak for one hour to a large group of community college students. Arrangements had to be made for the television videotaping, the lighting in the auditorium, the catered lunch, the payment of the honorarium, and the presence of the college's president.

All of these things came together for one fifty minute lecture for about three hundred plus students, most of whom knew little or nothing about the speaker or the Soviet Union and the massive changes taking place in that nation at this time in history. The speaker, Academician Alexander Alexanderovitch Fursenko, a member of the Soviet Academy of Sciences, was, in fact, not only talking about perestroika, but he was doing perestroika, as he openly criticized the government of the Soviet Union and the massive mistakes of previous leaders. To most of the students, brought to the auditorium by their teachers, he probably didn't seem that much different from all the other speakers they had ever heard speak on the Soviet Union, not realizing that what they were witnessing was nothing short of a miracle and would not have been allowed just three or four short years ago under a different soviet leadership.
\end{abstract}


At the luncheon for ten college staff members and the distinguished Soviet historian, an idea sparked much of the noon time gathering. Dr. Furshenko didn't know much about community colleges and asked a few questions about the size of the student body and what classes the students were taking. He had assumed that the college was much like any other higher education institution in the United states. He was quite surprised to learn about the different programs and activities of a two year college. He left campus with three catalogues under his arm vowing to ask many more questions about the community college and its role in American society.

Those attending the luncheon left with the conviction that maybe they had witnessed the birth of an idea that would find its way, with time, into another culture and, perhaps, change the way in which two societies would look at each in the future.

\section{STATEMENT OF THE PROBLEM}

The above incidents, several of just thousands that occur throughout the United states at the nation's community colleges each year, are small illustrations of the dynamics involved in the field of international programs. The world is, undoubtedly, getting smaller, with peoples and cultures drawing closer together with each passing day (Brademas 
1982). At the same time, we know that many community colleges are actively participating in the very process of bringing the world closer together (Diaz 1984). The community colleges of oregon and Washington states, gateway to the Pacific Rim, are, likewise, engaged in a variety of international educational activities, and are helping to create an awareness of an "international dimension" never seen before, nor studied before.

After vigorously scrutinizing the literature and speaking informally to community college practitioners throughout the United states, it became clear to this researcher that relatively little research or writing was being conducted in the area of community college practices in the field of international educational programs and activities. On the other hand and from a broader perspective of the general and popular literature, much is being written and said about both international education and international issues (Drucker 1989; Naisbitt 1983).

The problem, succinctly stated, is that leaders and students of the community college movement do not have either a theoretical or a knowledge base about international education. There does not exist a systematic guide or reference to either what already exists or a guide or reference to improve or initiate practices in this field. 
In spite of a scarcity of research on community college practices in the international arena at this time, there is little doubt that an "international dimension" is, indeed, developing at most, if not all, community colleges if for no other reason than the world is rapidly closing in on the district boundaries of the nation's two year colleges (Burn 1980). A race is developing between which force is moving more rapidly: The world to meet the community colleges or the community colleges reaching out to meet the world. Maxwell King and Seymour F'ersh (1987), two pioneers in community college international education, argue that the "international dimension" is not:

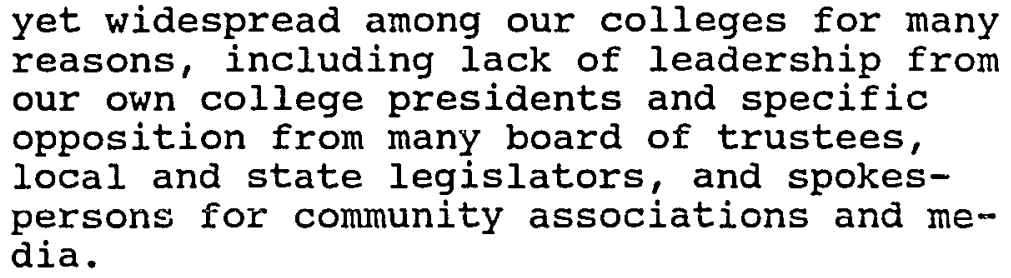

John Keyser (1989), president of Clackamas Community College in oregon, hinted that there are similar problems facing oregon community colleges when he asked the governor of oregon, Neil Goldschmidt, in an interview for the Community and Junior College Journal:

Why should community colleges be interested in the international arena? Given the mandate of community colleges to serve local constituencies, how can community college leaders build the political support needed to establish and fund international education programs? 
The governor empathetically argued that local boards and locally elected officials interacting with the community colleges "not develop a we/they sense of the relationship between American (community college) students and a global community." Governor Goldschmidt went on to say:

the international arena is no longer something "out there" to be responded to by people "over here." Community colleges are an excellent reflection of the local communities they serve. They are in a unique position to help break down the temptation to think and act provincially so we can all acknowledge and respect the reality of a global community. Perhaps more than any other segment of our education system, community colleges are ideally situated to think globaliy and act locally.

Keyser (1989) correctly pointed out that,

Oregon's community colleges sit across an ocean from 28 Pacific Rim countries that by the year 2000 will have 75 percent of the world's population and almost half of the gross world product. As the world moves into the Pacific Century, community colleges will be increasingly called upon to serve global education and training needs.

For students and researchers of the community college movement, a major problem exists in that we do not know much about how and/or why community colleges have developed an international educational "dimension" on either a regional or national basis.

In a 1988 letter to all the community, technical and junior colleges of the United States, the American Association of Community and Junior Colleges (AACJC), the leading 
advocate of the nation's two year institutions, indicated it was unable to "knowledgeably and adequately... represent fully and well the interests of the conmunity colleges in (the) international arena" without better information and a reliable data base. The AACJC is currently conducting a national survey of international education, activities, and programs in order to obtain more information about this growing phenomenon.

Charles Anderson (1988) issued a short report for the American Council on Education on international studies for undergraduates, with an emphasis on language training. The report only claims to be a "cross-sectional snapshot of what is happening nationally in international studies, and to serve as a frame on which additional extensive data" can be attached at a later date. This report by Anderson, like that of the AACJC letter, laments a lack of research into international educational programs and activities, both at the two and four year postsecondary levels.

practitioners and researchers really should know how and why forces are shaping the development of international education on the campuses of community colleges in the United states and in the states of oregon and Washington if we are to shape and guide the future. Ralph Waldo Emerson once advised us that, "the future belongs to those who prepare for it." 
SIGNIFICANCE OF THE RESEARCH

While little has been written about the actual role of community colleges in the development of an "international dimension," we do know, for instance, that we are, as former oregon governor Neil Goldschmidt has said, increasingly living in a global community and in a global economy. Economically, we see almost every day examples of the interconnectedness of national economies, such as that of the United States with Japan, Mexico, and Canada, to name but a few. The us economy, with its trade deficit and imbalance as a debtor nation, is tied very closely with the value of the Japanese yen, the value of the Mexican peso, and the value of the Canadian dollar. Never before in the history of the world are national economies tied so closely with other national economies. It is probably only a matter of time before an international currency will be used both in domestic arenas and on the international market place. Not so long ago, many Americans thought the dollar would be an international currency; many Japanese believe the yen will be that currency; but, others are arguing for a new currency to transcend nationalism completely.

Politically, many nations are inextricably tied together. Some are engaged in mortal combat, with no less than the globe itself threatened by the specter of war and the use of nuclear weapons. Some nations are tied together 
through mutual heredity, such as Great Britain and Canada, while others are tied together through the spirit of competition and the development of manufactured goods, such as the United States and Japan in autos and electronics. Many nations borrow extensively from each other in their political practices and constitutional arrangements, such as Great Britain and the commonwealth nations.

The forces of international economics and politics alone will not provide us with the insights and wisdom necessary to build a future interdependence with peoples from other regions and cultures (Andrews 1982). Education on a global scale about global issues is what will be needed to cope with the tremendous conflicts impending in a world based upon isolation and ethnocentrism (Barrows, et al. 1982) .

There are other forces simultaneously at work on this complex equation of international educational programs and activities and the role that community colleges are, and will, play in it (Davis 1987). One factor is that the United states is losing its preeminent position in the world gained after World War II. If the US is to remain competitive in peaceful world affairs, including international trade, a massive training program will have to be undertaken (Easton 1987). 
The president of sinclair community college in ohio,

David Ponitz (1989), points out that:

(A) fter World War II, America had 75 percent of the World's gross national product -- an impressive figure. Now that figure is less than 25 percent (and) imports from abroad now far exceed American exports. The need is real for small businesses and giant corporations to do a better job competing in a world economy.

Additionally, Barbara Moebius (1989), project director

for the international trade technical center at waukesha

County Technical college in Wisconsin, cites a recent US

Commerce Department report stating that:

since 1960 (the US) share of world trade has dropped from 18 percent to 15 percent. Today, 70 percent of US goods compete at home and abroad with foreign made goods. In 1986, the value of manufactured goods exported by the us trailed West Germany and Japanese exports by sizable margins. As a percentage of gross national product, US exports declined 20 percent from 1979 to 1983; this rate far exceeded that of any other major industrialized nation. only ten percent -- 30,000 out of 300,000 -- US firms export. Less than 250 domestic companies account for 85 percent of the exports. The Department of commerce estimates that 18,000 more firms have exportable products but ignorance of the opportunity and fear of the unknown are among the major factors preventing them from entering the global marketplace... For every $\$ 1$ billion in lost exports, 25,000 jobs have disappeared (in the US)... Any American business, no matter how small, with an exportable product must become a global competitor within the next decade or face the loss of 25 to 30 percent of potential gross sales. 
In spite of losing ground in international competition and marketplaces, another factor at work is that there are signs the people of the United States are not very well informed about the rest of the world, and that our knowledge base is less than what it was even twenty short years ago. Barbara Newell (1987) reported that one in five students in high school could not find the United States on a world map. other data report similar findings. As an example, researchers at Northern Illinois University (Chronicle of Higher Education 1989) surveyed 2,000 adults and concluded that only one in eighteen, or six percent, "had both a general understanding of how science is conducted and at least a minimal knowledge of scientific concepts." At the 1989 Governors' Association Conference held in Washington, D.C. (Oregonian Feb. 26, 1989), the chairman, governor Baliles of Virginia said, "the United States is not well prepared for international trade (because) we do not know the languages, the cultures, or the geographic characteristics of our competitors."

Also, the Educational Testing Service (oregonian Jan. 18 , 1989) reported that from a study of 24,000 students from Britain, Ireland, South Korea, Spain, the United States and in four Canadian provinces, "thirteen year olds in the United states scored dead last in mathematics and near the bottom in science." 
To complicate the matter even further, stephen Rhinesmith (1979) argues that:

(the) ability of Americans to contribute to an interdependent world is not just a matter of more information, but involves a much deeper issue affecting the values, beliefs, attitudes, and lifestyle of the American people.

He identifies the values of individualism, achievement, and independence, which are learned through socialization, as ones that do not lend themselves to an easy acceptance of "global interdependence" in the future. He further argues that these values, if not correctly understood, will "impede American participation in the global learning process, and inhibit capacity to contribute in shaping a common destiny with people from different backgrounds."

obviously, then, the community colleges, with an enrollment of 4.8 million students in the United states (ElKawas 1988), which represents forty-three percent of all undergraduates, have a unique opportunity to educate its students to the vagaries of a rapidly changing world (Sakamoto and Fifield 1987). Some, no doubt have seized the opportunity; others have not!

\section{PURPOSES OF THE STUDY}

The first purpose of this study was to identify and describe the current status of international educational programs and activities in the community colleges of oregon 
and Washington states as they existed in the 1989-90 academic year. In other words, what was the degree to which an "international dimension" had been established in the twoyear public community colleges of oregon and Washington.

A second purpose of this study was to identify three of the most highly developed community colleges, at least one from each of the two states, in the arena of international education in order to gain more of an understanding of how and why international education programs gain acceptance. The three case studies were used to draw generalizations and conclusions about the extent to which "successful" community colleges with highly developed international programs can assist others in this pursuit.

A third purpose of this study was to add to the body of knowledge and research on international educational practices at the nation's community colleges. This study sets out a new taxonomy or typology of international educational programs and activities not used thus far in the literature. The new taxonomy was primarily used as a parameter to better understand the dynamics of international education as it is practiced at the nation's community colleges and as a guide to the literature base.

And, a fourth purpose of this study was to provide useful information to those community college leaders inter- 
ested in starting or improving upon international education programs and practices.

\section{THE RESEARCH QUESTIONS}

The following research questions, derived from the researcher's interest and experience in international education, an exhaustive review of the literature, personal knowledge of current research, and clear purposes, defined the broad parameters of this investigation:

1. What is the current status of international education programs among the public comrnunity colleges of Oregon and Washington? and

2. How and why did the international education programs and activities evolve and develop at three of the most highly developed public community colleges of oregon and Washington?

\section{STUDY PROPOSITIONS}

Yin (1989) argues that the inquiry must go beyond the specific research questions in order to direct the study in the path of suppositions, hunches, or assumptions behind the questions. "Jach proposition directs attention to something that should be examined within the scope of the study" ( $p$. 30).

This dissertation concentrates on the following propositions: The international education programs and activi- 
ties of oregon and Washington community colleges evolved and developed through:

1. The efforts of strong presidential leader ship;

2. Large community colleges found in urban areas;

3. The presence of international students;

4. The presence of full-time international education administrators;

5. The presence of international education grants from external funding sources;

6. The presence of a strong global curriculum;

7. The presence of strong foreign language programs;

8. The presence of full-time faculty born in other countries;

9. The presence of full-time faculty who have lived and travelled abroad.

These study propositions compelled the researcher to exam any and all suppositions, hunches and assumptions that would result in some deeper understanding of international education activities and practices in the two state region.

\section{STAGES OF THE DISSERTATION}

The study was completed in several stages. The first stage was a complete search of the literature and personal follow-ups to known current research projects underway at the time. The second stage was the construction of two survey instruments capable of describing and collecting 
information about current practices and determining how and why certain elements within an international program were started and developed. The third stage also used the first survey instrument to subjectively discern from the data a profile on those public community colleges in oregon and Washington states that exhibited the most highly developed international educational programs and activities. The fourth stage was to conduct on-site interviews, using the second survey instrument, with key participants at each of the three community colleges selected as having the highest profile in the international arena. The last stage was used to draw conclusions and recommendations about current practices and future directions as the community colleges enter the last decade of the 20th century and embark upon international dimensions for the 21 st century and beyond.

\section{IIMITATIONS}

This study was conducted with several limitations. The first limitation was a reliance on the respondents interpretation of each question and their ability to convert the question into a numerical response. The questionnaire was designed to elicit as much numerical data as possible from a source that may or may not have had the information readily available. Each respondent was asked to fill in as much of the survey as they could relying, if need be, on estimates. 
The questionnaire was sent to campus presidents, many of whom sent it on to another person within the organization. Thus, the information is only as reliable as the respondent was diligent in getting "good data."

The second limitation of the study resulted from an inability to secure every community college's participation in the study. Five oregon community colleges and eight Washington community colleges ignored the many pleas for assistance in completing the questionnaire. Thus, any conclusions about the status of international education in the two state region is limited to those schools that participated.

A third limitation occurred in the case study step. It was physically impossible to spend all the time wanted with every participant identified as a key player in the development of international education programs. For instance, while the presidents gave of their time willingly, they weren't able to spend more than an hour or two with the author. Also, due to time and distance, only a very few interviews were conducted with critics of international education at the three campuses. Thus, a "balanced" case study was eschewed for a more representative view of the dynamics of evolution and development. Still, strengths and weaknesses were identified; but, however, by those people who were more inclined to support international education. 
International education has a dynamic of its own just by the inertia created by instant communications and rapid transportation. This study set out to find what was going on in the public community colleges of oregon and washington in the arena of international education. 


\section{CHAPTER II}

REVIEW OF THE LITERATURE

The purpose of this chapter is to provide an in-depth description of the professional literature relevant to the study of international educational programs and activities in the community colleges of the United States, with specific reference to the states of oregon and Washington. By describing a variety of research methods, theories, and conclusions of many of the leading authors and proponents of international education, this study was developed by the author of this dissertation.

Interestingly, the very first issue of the Junior College Journal (1931) included one article related to community college activities in Greece (author unknown). This same journal, although changing its name several times, continued to address the role of community colleges in the world on an intermittent basis. Only two issues in the fifty-eight year history of the journal have been devoted entirely to this topic: in 1984 and 1989. The professional literature is, however, growing, but at a very slow pace, and very little of it is based upon applied research (Hill 1979). The literature available made it very clear that the 
nation's community colleges are, in fact, heavily involved in international education (King and Fersh 1989). However, like the AACJC study cover letter cited above in chapter I indicated, there are very few systematic studies on what is actually occurring at the community colleges in international educational programs and activities. While only one dissertation was completed in 1988 on international education and the community college (Fifield), surprisingly, some of the most comprehensive general works on the community colleges in recent years failed to mention at all the role that two year institutions play in promoting and understanding internationalism (Cohen and Brawer 1982; Deegan 1985; and Parnell 1985) much less report on any applied research. When looking at the available literature on this topic the first problem encountered was trying to find a usable definition about what people were really saying whey they mentioned "international education" (Craig 1981). It seems to mean different things to different people at different times.

A rare, but rather complete, example of a working definition of the concept of international education and how it is applied to community colleges can be found in $\mathrm{king}$ and Fersh (1989), who stated:

International education in its broadest sense refers generally to all programs, projects, studies, and activities that help individuals to learn and care more about 
the world beyond their community and to transcend their own culture conditioned ethnocentric perceptions, perspectives, and behavior. International education should not only increase one's knowledge; it should also enhance one's wisdom and affinity for humanity.

The literature found was almost devoid of definitions and relied more on describing one or more of the activities or practices normally associated with those ideas that could in the broadest sense be called "international." It would appear, too, that this has caused some confusion in the literature because what one writer is calling international education may, in fact, be but one very small aspect of the issue (Anderson 1988).

By sorting through the various activities described in the literature, a new taxonomy or typology of activities and practices was created by the author of this dissertation in order to conduct a comprehensive review of the literature. From that starting point, it was discerned that the "programs, projects, studies, and activities" that King and Fersh (1989) referred to could be categorized into at least ten areas in order to sort out the parts and create a coherent whole. The areas selected for this review and which constitute this taxonomy are:

1. The recruitment and education of international and/or foreign students;

2. Foreign born faculty;

3. Curriculum related to non-US topics; 
4. Internationalizing the curriculum;

5. International trade and business education;

6. The establishment of "sister college" relationships;

7. The establishment of community colleges abroad;

8. Consortia arrangements for international education;

9. Study abroad programs for faculty and students; and,

10. Overseas military programs.

\section{A NEW TAXONOMY OF INTERNATIONAL EDUCATION}

A new taxonomy on international education was especially created for this study to assist the author, and others, to clearly define what people meant by the term international education. There was, and probably still is, little agreement on exactly what people mean when they speak about international education. The taxonomy, with its ten elements, allows people to organize their thoughts and articulation about the subject. When a person can clearly identify that there are at least ten different activities associated with the term international education everyone can be in agreement about the meaning. The new taxonomy was first used to organize the literature search. Then, the new taxonomy was used throughout the other parts of the disser- 
tation to assist in the logical organization of thought and discourse.

\section{RECRUITMENT OF INTERNATIONAL STUDENTS}

In 1990, there were more than 407,000 international students studying in the United States (Chronicle of Higher Education 1991) representing more than seventy countries (p.18). Elaine El-Khawas (1988) estimated that about 52,000 international students were studying at community colleges in the United States -- or about one-third of all international students at the undergraduate level. This number has not, interestingly enough, changed significantly from a decade ago (Diener 1978).

In Diener's 1978 study, he profiled the international students attending community colleges this way:

Male students outnumbered females two to one; most foreign students entering the community college did so directly from their home country (72\%); about 80 percent of all international students who attend two year institutions were enrolled in associate degree programs, with engineering (23\%) being the most popular academic area with business and management (16\%) following behind.

A very interesting finding by Diener (1978) was that more than three-quarters of all international students attending US community colleges came from third world countries. He also pointed out that international students were most likely to study in New York, California, and 
Florida, with the majority of attendance at fewer than ten schools. One community college, Miami-Dade of Florida, claimed they enroll more international students than any college or university in the United States with 5,757 international students in 1990 (Chronicle of Higher Education 1991, p. A41). The entire state of oregon, by contrast, enrolled about 6,100 international students at all institutions of higher education, including community colleges. Fall 1988 statistics (Russell 1989) indicate that 714 nonresident alien (i.e., international) students were attending community colleges in oregon. Males numbered 410, while 304 were females, which differed from Diener's 2-1 ratio in his 1978 study. According to Seppanen (1989), Washington state does not keep a system-wide record on international students attending community colleges as a result of new federal reporting procedures. She estimates, however, that there were about 1,500 international students enrolled in the community colleges of Washington state. There were 7,625 international students at all washington colleges and universities in 1990 (Chronicle of Higher Education, 1991, p. A41).

A strong schism exists within every community college as to whether or not international students should be recruited for the host campus (Chisti 1984). One argument states that community colleges are local districts funded 
primarily by local taxpayers and that recruiting and educating the international student is outside the basic mission of the institution (Ebersole 1989; King and Fersh 1987; Wygal 1979). The other side of the argument, which was clearly stated in the AACJC monograph, Building Communities: A Vision for a New Century, states that community colleges are a part of the world and should be serving a larger community than that marked with narrow, parochial boundaries (Parnell 1988).

For those community colleges wishing to embark upon an active international student program, the former argument is very real and an obstacle not easily penetrated; thus, some community college leaders simply avoid the recruitment and education of international students as an integral part of their "international dimension."

\section{FOREIGN BORN FACULTY}

Another indication of the "internationalization" of a community college can be found in the second dimension of the taxonomy in the number of foreign born faculty on any given campus. The literature is virtually silent on this interesting aspect of international education on any given community college campus.

Yet, it is well-known that foreign born faculty are present on almost every community college staff. As the 
United states has opened its doors to immigrants throughout the history of this country, many persons born in another land have completed the necessary education to become community college instructors. Others havel come from foreign lands as adults with exceptional academic credentials to assume roles in higher education, including community colleges.

The extent to which the foreign born faculty contribute to the "internationalization" of a campus is heretofore undocumented. One can only surmise that their presence in some way adds to the total dimension of international education.

\section{NON-US CURRICULUM}

While the curriculum on international issues does not appear to be attracting significantly new numbers of students today (The Governors' Association 1989), the Iiterature clearly reveals that the state of international education for two and four year postsecondary education as well as in the high schools must have hit rock bottom in 1979 . In one of the most important documents marking the turning point in an understanding of the depths of this ignorance among the people of the US, the President's Commission on Foreign Language and International studies (1979) warned then President Carter that "they had discovered and docu- 
mented weaknesses in the area of our inquiry which, in our view, pose threats to America's security and economic viability" (p. 1). The Chair, James A. Perkins, the former President of Cornell University, went on to say:

The problem extends from our elementary schools, where instruction in foreign languages and cultures has virtually disappeared, to the threatened imminent loss of some of the world's leading centers for advanced training and research on foreign areas. Such specific educational neglect, moreover, is reflected in public uncertainty about the relationship between American interests and goals and those of other peoples and cultures... Nothing less is at issue than the nation's security. At a time when the resurgent forces of nationalism and of ethnic and linguistic consciousness so directly affect global realities, the United states requires far more reliable capacities to communicate with its allies, analyze the behavior of potential adversaries, and earn the trust and the sympathies of the uncommitted. Yet, there is a widening gap between these needs and the American competence to understand and deal successfully with other peoples in a world of flux... There is little safety behind a Maginot line of scientific and scholarly isolation... The future will belong to nations that are wise as well as strong.

This report made it very clear to all who read it or about it that the United States needed desperately to revise its thinking about global issues and America's role in the world. The Commission also very clearly called for the educational community to take the lead in educating our students to the vagaries of the world. At the heart of the 
reforms called for was a strengthening of those curricula that could be labelled non-Us topics.

The Commission members, but especially S. Frederick starr, were most concerned about the inability of us students to take foreign language training. He pointed out:

that only 15 percent of all high school students were studying a foreign language, a drop of more than sixty percent from 1915, when the percentage was greater than thirtysix percent (p. 10).

More alarming was the fact that most students were studying only four languages, and less than 3,500 students were studying Russian (our primary adversary in the world) at the second year level, fewer than 200 students were in the second year of high school Japanese, and fewer than 200 students were in the second year of chinese language training, out of a total of $3,800,000 \mathrm{high}$ school students taking any foreign language at all (p.12).

Lambert (1984) believes that the United States made substantial efforts at promoting foreign language and foreign area studies in higher education during and after World War II. He maintains this was true through the immediate post-sputnik era, but for a variety of reasons these programs faltered badly in the $1970^{\prime} \mathrm{s}$. Most of the foreign language and foreign area graduates were employed by either government or education. Lambert also cites the 1979 Rand Study, Foreign Language and International studies Specialists: The Marketplace and National Policy, to suggest that not only were government and education falling behind in the 
recruitment and retention of specialists but businesses "have been slow to attribute any value to a prospective American employee's competency in the language or culture of one of the countries where businesses operate" (p.137).

A year earlier than Lambert's report, The National Commission on Excellence in Education (1983), chaired by David Pierpont Gardner, recognized that nothing less than the United States itself was at risk if the schools, colleges, and universities of this country could not produce better students.

History is not kind to idlers. The time is long past when America's destiny was assured simply by an abundance of natural resources and inexhaustible human enthusiasm, and by our relative isolation from the malignant problems of older civilizations. The world is indeed one global village. We live among determined well-educated, and strongly motivated competitors. We compete with them for international standing and markets, not only with our products but also with ideas of our laboratories and neighborhood workshops. America's position in the world may once have been reasonably secure with only a few exceptionally well-trained men and women. It is no longer true.

Among the many recommendations in $\mathrm{A}$ Nation at Risk was one that urged the nation's schools to adopt two years of a foreign language for college bound students. All the recommendations were aimed at making the United States more competitive in the international arena in the next century.

Foreign language training appears to be the most obvious example of non-Us curricula changes, especially as the 
community colleges (and others) begin to introduce foreign language training that meet the needs of students, such as Japanese, Chinese, Swahili, or even sign language, that impart a knowledge about other cultures more directly. There are other examples of non-US curricula changes taking place in higher education. For instance, many community colleges have recently introduced new courses on specific nations not previously taught: History and Politics of Japan; History and Politics of China; History of Central America; History and Politics of Africa (or specific nations and regions of Africa); History and Politics of Israel and the Middle East. These courses or curricula have contributed to an understanding of other nations and cultures with or without a reference to the United States (Fersh 1979).

Unfortunately, there is a real lack of information and research on the current status of non-Us based curricula. However, those community colleges wanting to change their curriculum without introducing new courses or new programs turned to another approach to international education: internationalizing the curriculum.

\section{INTERNATIONALIZING THE CURRICULUM}

If it wasn't possible to introduce new courses on the history, culture, and politics of other nations into the curricula of a community college, some proponents of inter- 
national education suggested that community colleges infuse into existing courses materials on other cultures, other nations, and other practices found in the global community (Grant 1979). In addition, an effort has been made to create specialty courses detailing the rise of "internationalism" in contemporary affairs (Kerr 1979). These courses, usually called International studies or International Education, are stand alone classes designed to introduce the student to the world without reference to a specific national culture, but focus on global issues (Leinwold 1983). Peace Studies can also fit this description. King and Fersh (1979) were among the first to foster the concept of "internationalizing the curxiculum." Their idea was not only to strengthen existing traditional non-US curriculum bu'c to infuse those ideas found in other cultures into the traditional American-based curriculum. They not only advocated new courses and new materials in existing courses but saw the entire enterprise as a vehicle for staff development (see also Harari 1981).

Sidney Grant (1979) demonstrated how "internationalizing the curriculum" can have a very positive effect on a community college campus citing the early work of three community colleges that made the commitment to international education: Kirkwood Community College (IA); North Shore Community college (MA); and Monroe community college (NY). 
Each focused on the writing of modules (Kirkwood and Monroe) or components (North Shore) that could be adapted to any existing course depending on the imagination and creativity of the course instructor.

The module or lesson plan approach to internationalizing the curriculum has been followed by a number of community colleges, including Mt. Hood Community college in oregon, which has more than seventy such modules in their library currently. Internationalizing the curriculum is relatively cost effective and has wide-spread application to a faculty (Cleveland 1979).

The Chronicle of Higher Education (March 29, 1989) reported that Triton Community College and the National Endowment for the Humanities were working together on a project that would revise the general education courses at Triton to include a better international perspective. "Under the college's proposal," according to the report, "students working toward a two-year degree in one of many technical fields might be required to take a course on the nature of work that also includes the perspective of workers in other countries" (p. A17).

Some Florida community colleges have suggested that international education be a part of the general education requirement for graduation (Greene 1985). Brevard Community 
College and Miami-Dade Community College have, indeed, instituted such a requirement (respective college catalogs). Internationalizing the curriculum has provided an inducement to practitioners to develop other areas of curriculum interest, including International Trade and Business programs.

\section{INTERNATIONAL TRADE AND BUSINESS EDUCATION}

The US international trade deficit now stands at an all time high of more than 3.4 trillion dollars and continues to grow at a rate of more than one billion dollars a day (The oregonian, January 2, 1991). From late 1988 to the end of 1990, the trade deficit grew more than 1.5 trillion dollars. These statistics tell us that the United states is now importing more than we are exporting and the prospects of reversing this position are slim. The United States now is a debtor nation for the first time in this century, owing more to other nations than what is owed to us. The President's Commission (1979) pointed out that international trade involves one out of every eight manufacturing jobs and one out of every three acres in farmland in the United states is being devoted to international trade issues. More than twenty-two percent of the gross national product is involved in international trade as well. Twenty percent of the industrial production is for export, and one of every 
six production jobs is dependent on exports. One-third of US corporate profits are from international activities, and fully forty percent of farm production is for exportation, according to the President's Commission (1979).

Speaking at the Annual Meeting of the International Studies Association, Tilly Harris (1981) told her audience that international trade in the state of oregon increased from 1.2 billion dollars in 1970 to 2.8 billion in 1975 and increased again to 6.4 billion dollars in 1980. According to the International Trade Institute of Portland state University, the 1987 totals for both import and export were $\$ 8.48$ billion for oregon. The same source indicated that the total for washington state was $\$ 33.4$ billion for a total of $\$ 41.9$ billion for the two northwest states in 1987 . In spite of overwhelming evidence to suggest that all of higher education in the United States should be moving to more involvement in the international arena, little evidence is present to indicate such a move (Mahoney 1985). Community colleges, with a history of local traditions and boundaries, offer their students very little in the way of international trade and business education (Wood 1986). There are, of course, some exceptions to this rather bleak view. Under Title IV(b) funding from the US office of Education, International Education Division, the following community colleges have established International Business 
and Trade Centers in recent years: Chicago city Colleges, Loop College (IL); Vista college (CA); Bergen Community College (NJ); st. Louis Community college (MO); Coastline Community college (CA); Bunker Hill Community college (MA); and, central Piedmont community college (NC) . Waukesha County Technical College (WI), Normandale Community College (MN), Portland Community college (OR), and Middlesex Community College (NJ) have been able to draw together funding from a variety of sources other than Title IV(b) and have operated trade centers focusing on international or international small business issues on their own. In addition to the above individual community colleges, several community college consortia (Gleason and Hazelwood $1987)$ exist to enhance international trade centers and international business education (see discussion below). clearly, though, these few community colleges represent a minority of the more than 1,200 community colleges in the United states. In his dissertation, Santiago wood (1986) surveyed ninety California community colleges (out of 106) and discerned that only sixteen (18\%) said they had offered classes or programs in international trade and business, while only two (4.5\%) required international trade or business courses for their business majors, and no community college in California required a course in international education for completing an Associate of Arts degree ( $p$. 
95). In Vassilou's 1984 nationwide study, she discerned that only $60(14 \%)$ of the 432 responding community colleges offered any formal course work or programs related to international business. The two studies (Wood 1986 and Vassilou 1984) point out that very few community colleges are engaged in international trade and business activities at a time when international trade and business is on the rise. Frank Albin (1985), writing on US-Japan trade, insists that:

Focusing on Japan and the United States from a 'global perspective' will add a dimension that is often lacking in American education and business conduct. Americans have traditionally dwelled on their own large domestic economy, the westward movernent, being the melting pot, and being a nation preoccupied with itself.

He then goes on to describe at some length how the Japanese conduct their business from the perspective of a "homogeneous nation of people" used to working in groups. The latter perspective, of course, is not usually taught in American colleges and universities. Thus, there is confusion and misunderstanding between the two nations when they try to conduct business together. Advocates of international education, especially in trade and business, argue for greater offering of classes and courses better to prepare today's students for the world of tomorrow (Blanco and Channing 1985). 


\title{
SISTER COLLEGE RELATIONSHIPS
}

\begin{abstract}
During the summer of 1989, the City of Portland was host to an international conference on "sister city" relationships (The oregonian July 18, 1989). More than 300 delegates from thirty nations and representing more than ninety sister city relationships were in attendance. Created in the 1950's to promote world peace and understanding, the sister city concept is now in full bloom, especially so with air travel and electronic communications so rapid. one of the spill over effects from the sister city concept was the creation of sister college relationships between American community colleges, colleges, and universities and their counterparts throughout the world (Robinson 1987). Unfortunately, there exists no literature on the extent of these relationships. To this researcher, it would appear that, for the most part, these relationships between us community colleges and higher education institutions in other countries are informal and exist more for symbolism than for substance at this time.
\end{abstract}

\section{COMMUNITY COLLEGES ABROAD}

The community college, or two-year college, is a uniquely American educational product (Johnson 1961 and Gleazer 1968). Born at the turn of the century, nurtured during the inter-war years, and fully developed after World War II to 
meet local community needs, the community college is being "discovered" by the rest of the world (Gannon 1983). While there is very little literature available on this practice, there are a few community colleges actively engaged in either assisting other nations in the development of their own community colleges or in operating branch campuses in other nations.

From a variety of newspaper accounts (The oregonian, The Seattle Times, The Chronicle of Higher Education, and the "Bulletin Board" section of the latter publication), several community colleges are now operating branch campuses in Japan. Mt. Hood Community College (OR), Edmonds Community college (WA), Green River Community college (WA), st. Louis Community College (MO), and Los Angeles City College (CA) are the latest entries in operating off-shore campus centers in Japan.

St. Louis Community College (MO) has an off-shore campus in Syria, and the former chancellor, Michael Crawford, spent part of August, 1989, in the Soviet Union negotjating for a possible partnership with the Russians in establishing a community college (personal correspondence). Waukesha County Technical college (WI) has active operations in Taiwan and in Turkey (personal correspondence). Several US community colleges, such as El Paso Community college (TX) and San Diego Community College, conduct training in 
Mexico on a regular basis (Justiz 1980 and The Chronicle of Higher Education, oct. 1991). And, many other community colleges participate in semester abroad programs in facilities that are rented directly or through international consortia arrangements.

These projects which establish community colleges in other nations are operating with the premise of educating both us nationals studying abroad and the nationals of the host country. Again, there is very little available to the researcher in the literature about the extent of community colleges operating branch campuses in other countries.

\section{CONSORTIA ARRANGEMENTS}

American community colleges operating as single units often can not afford to get involved with international projects from either a political or economic reality due to local concerns. Even though the leadership may very much want to be involved, the only alternative to "going it alone" is to belong to an international consortium of two or more community colleges (Adams 1979 and Gleason and Hazelwood 1987). The consortium is usually based on a common interest in one country or region of the world or a common bond, such as being in the same state or in the same region. King and Fersh (1989) point out that there are "more than a dozen" consortia working to assist individual commu- 
nity colleges organize and develop any and all international programs and activities. The American Association of Community and Junior Colleges (AACJC) began a consortium for the development of community college interests in international activities in 1976. This consortium helped to organize a major project between the government of Nigeria and more than thirty community colleges around the country in the late $1970^{\prime} \mathrm{s}$, bringing more than two thousand Nigerian students to the United States to study (Jacobsen 1979).

Today, more than one hundred community colleges belong to the AACJC International Intercultural Consortium, of which thirty are foreign operated community colleges, mostly in Canada. The major activity of this consortium is an annual convention just prior to the AACJC national convention which provides a forum for consortium members to focus on an issue of importance. Under the leadership of Michael Paradise, the consortium is now in a position to conduct research and develop international programming for its members.

A major player in community college international consortia is the Community colleges for International Education, with the main offices at Brevard community college in Florida. Also founded in 1976, Maxwell King, president of Brevard Community college, was in a leadership role, bringing fourteen community college members and twenty-seven 
associate members together for the purposes of pursuing a variety of international programs and projects during the more than thirteen year history of the organization. Another world-wide consortium is EPIC, Educational Partners for International Cooperation. This international consortium was formally organized about the same time as the AACJC and CCIE consortia through the efforts of Phil Gannon, retired president of Lansing Community College in Michigan and the former president of Mt. Hood Community College in Oregon, stephen Nicholson. Today, the consortium is made up of seven American community colleges and two technical twoyear schools in Taiwan.

Several state consortia on international education are in existence (Greene 1979). Arizona, California, Florida, New Jersey, Illinois, Oregon, and Texas all have state-wide consortia promoting international education (King and Fersh 1989). There is one Pacific Northwest regional consortium on international education (Kelleher 1985). Headquartered in Seattle, the Northwest International Education Consortium includes twenty-seven colleges and universities and two nonprofit organizations interested in promoting international development activities among its members. The NaIC is now ten years old and, like the AACJC consortium, is poised to be more active in the near future as the world grows smaller 
each day and the spotlight is again on international education.

\section{STUDY ABROAD PROGRAMS}

Many four-year colleges and universities operate study abroad programs, which have been in existence practically from the day Harvard College opened its doors in 1636. Future ministers were sent to Europe to learn about the life and times of the church and its importance to the new world. Today, a typical private or public college or university might have a dozen or more possible contacts and opportunities to study in virtually every country in the world. However, community colleges have been very slow to recognize the value of study abroad programs (Berry 1984). Due to the low cost of tuition and the idea that community colleges are primarily for commuter students or students only interested in learning a job skill, local boards of trustees and administrators have been slow to advance the concept that an international experience will make the student a better educated person, regardless of their academic interests (Boyer 1978). In a speech at the annual convention of the AACJC, Boyer (1978) stated:

I totally reject the disturbing notion that international education was the province of the senior colleges... I am convinced the two year colleges not only have a right to establish international linkages -- they should lead the way. 
The American Institute for Foreign Study, an organization begun in 1964, has recently been active in assisting five oregon community colleges (Chemeketa, Clackamas, Lane, Mt. Hood and Portland) in establishing a consortium for the purpose of recruiting faculty and students to teach and study in England each spring quarter. This is one response to overcoming the view that community college students can not or will not commit to a study abroad program. Rockland Community College in New York (Backman 1984) has developed a core curriculum around an extensive study abroad program among the community colleges of the United states. Rockland Community College acts as a liaison for other community colleges wanting their students to take credit courses in Europe and Israel at the same time it offers area studies programs for its own students. This is a very extensive, and expensive, curriculum that the Board of Trustees of Rockland Community college feels is important to the life and culture of their institution (Berry 1984). The United States Information Agency administers the Fulbright-Hays program, which allows many community college faculty each year to study abroad on a fellowship or teach at a foreign college or university for several weeks or months. Several private not for profit organizations also can arrange for study abroad opportunities for faculty. 
Once again, the literature did not reveal very much information about research conducted on study abroad programs at any level of education, be it postsecondary or high school.

OVERSEAS MILITARY PROGRAMS

While not normally perceived to be an integral part of international education, a case can be made for including overseas military programs in this typology. Faculty, staff, and students studying at an overseas off-campus location, whether sponsored directly or indirectly by the military for military personnel and/or their dependents, under the auspices of an accredited community college, are enjoying all the benefits of an international experience very much like a study abroad program. The fact that the branch campus is being funded by a military contract has no bearing on the experience, particularly if the faculty require off-base or off-campus activities to supplement instruction.

From the limited literature and from personal knowledge, at least four community colleges are engaged in Department of Defense overseas contracts: Big Bend Community College (WA); Central Texas Community College (TX); Florida Community College at Jacksonville (FL); and, the Los Angeles Community College District (CA). The best known and, proba- 
bly the most extensive, overseas contracts with the US military for postsecondary education is the University of Maryland, which has more than thirty locations around the world.

There may be others engaged in overseas military programs but due to a scarcity of information from the literature on this topic only further research will reveal any such arrangements.

\section{CONCLUSION}

There is, in conclusion, a growing, sizable body of literature on international education and the community college. The literature does contain many descriptions of international education activities of individual colleges. The available literature, however, tends not to be research based but prescriptive in nature. Edward Blankenship (1980) strongly decried the lack of research based literature over a decade ago. The same can be said now! 


\section{CHAPTER III}

\section{METHODOLOGY}

The organization of research must contain its own inherent logic from inception to conclusion. Almost all authors on the conduct of research stress the importance of clearly stating the details of the approach or approaches used in reaching new knowledge (Kaplan 1964). The history of philosophy suggests that the conduct of research was accomplished, first, through deduative and, later, through inductive methodology (Best 1977).

John Dewey (1938) set forth the "scientific methodology" of a deductive-inductive process with the following five criteria:

1. Identification and definition of the problem;

2. Formulation of a hypothesis -- a hunch, an assumption, or an intelligent guess;

3. Collection, organization, and analysis of the data;

4. Formulation of conclusions; and,

5. Verification, rejection, or modification of the hypothesis by the test of its consequences in a specific situation.

The research, then, must begin by examining in detail the approach employed in the conduct of the inquiry. 
Contemporary research paradigms existed to satisfy the demands of a comprehensive analysis to render this project complete. This study, born of a curiosity about the role of community colleges in implementing sound international education programs, progressed by sharply defining the problem under examination, stating the research questions, and exhaustively exploring the literature for both an appropriate set of questions and for appropriate research paradigms.

THE RESEARCH DESIGN

This research was planned around five objectives: To create and utilize a taxonomy about international education practices; to survey the public community colleges of oregon and Washington to determine the extent of current international education practices; to select three exemplary community colleges from those surveyed; to conduct three in-depth case studies; and, to analyze and report findings and recommendations on the strengths, weaknesses, and contributions of these community colleges to international education practices.

According to Robert Yin (1989), the research question or questions will tend to direct the researcher toward an appropriate design or designs.

(t) he first and most important condition for differentiating among the various research 
strategies is to identify the type of research question being asked (p. 19).

The specific research questions were:

1. What is the current status of international education programs among the public community colleges of oregon and Washington?

2. How and why did the international education programs and activities evolve and develop at three public of the most highly developed community colleges of Oregon and Washington?

Since a "what" type of question, according to Robert Yin (1989), is exploratory in nature and can utilize different research designs and "how" and "why" questions will lead to a research design utilizing or "favoring case studies, experiments, or histories" as the choice of methodology ( $p$. 19), two separate research designs were integrated into one and used to complete this project.

The first design, a descriptive statistical assessment survey (Hoaglin 1982 and Weisberg 1989) of current international education practices in the community colleges of oregon and Washington, was used to construct, compile and analyze the initial survey results, which can be found in Chapter IV.

The second design, a descriptive multiple case study (Hoaglin 1982 and $Y$ in 1989), was used to construct, compile and analyze three exemplary case studies of international 
education programs at community colleges from within the two state region and can be found in chapter $\mathrm{V}$.

After analyzing the survey results and compiling the three case studies, the findings and conclusions surrounding the study propositions reached in this study are reported in Chapter VI.

The integration of the two designs into one research project is strongly advocated by both Hoaglin (1982, p. 128) and Yin (1989, p. 90) as the assessment survey results can lead a researcher to new evidence and/or confirm the presence of the phenomenon detailed in one or more case studies.

\section{STUDY PROPOSITIONS}

Yin (1989) argues that the inquiry must go beyond the specific research questions in order to direct the study in the path of suppositions, hunches, or assumptions behind the questions (p. 30). "Each proposition," according to Yin (1989), "directs attention to something that should be examined within the scope of the study" (p. 30).

This dissertation concentrates on the following propositions: The international education programs and activities of Oregon and Washington public community colleges evolved and developed through:

1. The efforts of strong presidential leadership; 
2. Large community colleges found in urban areas;

3. The presence of international students;

4. The presence of full-time international education administrators;

5. The presence of international education grants from external funding sources;

6. The presence of a global curriculum;

7. The presence of foreign language programs;

8. The presence of full-time faculty and staff born in other countries;

9. The presence of full-time faculty and staff who have lived and travelled abroad.

These study propositions prompted the researcher to.

look for any and all suppositions, hunches and assumptions that would result in some deeper understanding of international education activities and practices in the two state region and are the focus of the findings and conclusions reached in this research.

\section{POPULATIONS AND SUBJECTS}

The study population considered for the assessment survey was all forty-three public community colleges from the states of Oregon and Washington (see Appendix B). The subjects of the assessment survey were community college presidents (or their designees). Those individuals identified in the survey as having a role in the evolution, development, and practice of international education programs and 
activities were the subjects of the three descriptive case studies.

\section{INSTRIMENTATION}

As was noted in chapter I, it was possible by sorting through the various international education programs and activities described in the literature to create a new taxonomy or typology of activities and practices in order to conduct a comprehensive review of the literature. From that starting point, it was discerned that the "programs, projects, studies, and activities" that King and Fersh (1989) referred to could be categorized into at least ten areas in order to sort out the parts and create a coherent whole.

After the literature review was completed, the newly created taxonomy or typology was also used to construct a survey instrument (see Appendix D) to ascertain current international education practices among the public community colleges in Oregon and Washington states. The survey instrument is linked to the new taxonomy by statistical weights for the purposes of selecting three highly developed or high profile community colleges engaged in international education practices in the two state region. The results of the survey questionnaire are reported in chapter IV.

The new taxonomy included:

1. The recruitment and education of international and/or foreign students; 
2. Foreign born faculty;

3. Curriculum related to non-us topics;

4. Internationalizing the curriculum;

5. International trade and business educa tion;

6. The establishment of "sister college" relationships;

7. The establishment of community colleges in other countries;

8. Consortia arrangements for international education;

9. Study abroad programs for faculty and students; and,

10. Overseas military programs.

A second instrument, an interview protocol (Yin 1989), was constructed from the work of Earl Backman (1984) to counsel the researcher during the three on-campus visitations conducted at the case study locations (see Appendix F). The second survey instrument, while open-ended and constructed around the second broad research question of how and why international education programs and activities evolved and developed at the three community colleges being studied, was used to control the free flow of information across all three campuses and not to overlook the commonalities sought for confirmation, comparison, and triangulation (Guba 1967). The results of the case studies are reported in Chapter $\mathrm{V}$. 
PROCEDURES AND ANALYSIS

The preferred methodology for this research was designed around the descriptive multiple case study strategies recommended by Robert Yin (1989), whose definition states:

A case study is an empirical inquiry that: * investigates a contemporary phenomenon within its real-life context; when *the boundaries between phenomenon and context are not clearly evident, and in which *multiple sources of evidence are used (p. 23).

Yin goes on to say that "a further distinction among history, case study and experiment" should be made when the researcher can determine "the extent of control and access an investigator has over actual behavioral events" (p. 19). The questions posed in this research into international education among the public community colleges of oregon and Washington ruled out the possibility of control over the behavioral events occurring. Likewise, an historical study was not the preferred method as access and focus was on a "contemporary phenomenon within a real-life context." Thus, the descriptive multiple case study research design was employed for this project. 


\section{Assessment study}

Because the literature did not reveal any significant information about international education programs at any of the oregon and Washington community colleges, a survey instrument was devised around the newly created taxonomy to determine current practices (see Appendix C). In addition, the survey instrument was used to determine which three community colleges should be considered the most highly developed in the region and the object of case studies. A pilot test of the survey questionnaire was conducted in May and June of 1990 with two community college presidents at Yuba commurity college in California and onondaga Community college in Syracuse, New York. Both presidents took approximately twenty-five minutes or so to fill out the forms and return them. Each also made comments on the possible ambiguities they found in several of the questions. Several minor revisions and one major revision were made to the original survey instrument as a consequence of the pilot tests conducted prior to administering it in the region.

The survey questionnaire instrument was sent to every public community college president in oregon and Washington during the month of July, 1990. The four page survey was accompanied with a cover letter explaining the purposes of the project (see Appendix A). In addition, a stamped, selfaddressed envelope was included to help assure a high return 
rate. After three weeks, an initial tabulation was made on the meager returns. A second letter was sent in mid-August, 1990. More completed surveys came back filled out. Followup telephone calls were then made to those community colleges that had not responded by the end of August and into early september. As a consequence of the telephone calls, several more questionnaires were sent out by mail and several more completed surveys were received. By the end of october, it was apparent that most, if not all, the surveys had been returned that would be coming. One last effort by telephone was made to those schools still not responding to the calls for their participation. By November, twentyeight community colleges had returned completed surveys. Two presidents sent letters declining to participate. One more effort was made to contact individuals known to have job responsibilities for international education on four "key" community colleges. Two sent their surveys back within three weeks. Finally, a decision had to be made to cut off any attempts at getting full participation. When data entries were completed and writing began in mid-December, a total of thirty-three schools out of forty-three had responded.

From the survey, which contained forty-six information items, there were forty-one items that produced data in either alpha or numeric format that were chosen to examine 
the status of international education and to rank all of the responding schools (see Appendix D and E). The data were then converted to a complete numeric system in order to utilize computerized statistical manipulations. All demographic data were kept separate from the rest of the responses. That is, neither a school's size nor other demographic factors were used to determine which community colleges would be chosen for a case study.

The data were then examined through two different sets of criteria in two data runs. The first examination of the data was on the basis of how many total points each school received irrespective of any weighting or balancing system. Thus, a school with, say, 1,500 international students received 1,500 points on that one question alone. In the first examination, every "yes" answer received one point. If a school was operating a foreign branch campus and answered "yes" on the survey, they also got only one point for that particular answer. It was very obvious that a raw total point system would not necessarily reveal the most developed or most active community colleges in the field of international education in the two state region.

A differential weighting system was assigned to each of the forty-one questionnaire items in order to try and bring equity and balance to the study outcomes. The exact weighting for each of the forty-one items was a difficult task 
inasmuch as there were obvious differences in the numbers each variable could produce or be assigned. For instance, should having a foreign branch campus weigh the same as having one foreign language class taught on the home campus by assigning only one point to each? Further, should each foreign student be counted and have the same weight statistically as, say, the number of foreign born faculty or the number of international education administrators or operating a foreign branch campus? It was thought not. Fourteen of the forty-one items were examined in much detail, and considerable thought was given to each and every item as to how to achieve balance and weights appropriate to selecting the three case studies. The following, albeit, subjective assignments were used for each of the fourteen items that could not be assigned by their actual numerical data:

Question \#5 -- Number of International students: One point was assigned for every ten international students;

Question \#11/12/13/14 -- Percentage of time by administrators, faculty, advisors, and staff to International Education activities: One point for every 25\% of a person's time devoted to international education activities;

Question \#17 -- English as Second Language and English as Non-Native Language Students: One point for every 100 students;

Question \#18c/31b -- Number of Sections of Foreign Language and International Education classes: One point for every five sections; 
Question \#19 -- College Mission statement: Five points were assigned if a college included a reference to an international mission in their basic mission statement;

Question \#21 -- Number of students studying Abroad: one point for every five students studying abroad;

Question \#25 -- Faculty Travel Abroad: One point for every faculty member who travelled abroad;

Question \#26 -- Overseas Military Contracts: Five points for each overseas military contract;

Question \#27 -- Foreign Branch Campus: Ten points for each foreign branch campus; and,

Question \#33c -- Percentage of Degrees Awarded to International students: one point for each $10 \%$ increment listed (e.g., 5 points for fifty percent of international students being granted degrees).

All the rest of the questions, twenty-seven items, received actual number of points according to the responses. For instance, if a community college listed five different foreign languages, the school received five points in that category .

After resolving many of the problems associated with trying to reach an equitably balanced weighting system, total points were calculated for each community college that responded to the survey. (See Appendix E for the complete weighting system and the final rank-orders.) It turned out, however, that the most important element in the final selection of the top three schools in the two state region was the richness and variety of international education programs and activities each school demonstrated across the taxonomy 
of ten dimensions or categories of international education activities established earlier in this study (see chapter II). Thus, the three case studies were selected.

\section{Case study}

When the assessment survey on current practices was completed and three community colleges were selected as case studies, the procedures for conducting a descriptive multiple case study were reviewed again.

Robert Yin (1989) argues that all research designs, including case studies, must stand up to four tests: construct validity; internal validity; external validity; and reliability (p. 40). The explanations are:

Construct Validity: establishing correct operational measures for the concepts being studied;

Internal Validity: establishing a causal relationship, whereby certain conditions are shown to lead to other conditions, as distinguished from spurious relationships;

External Validity: establishing the domain to which a study's findings can be generalized; and,

Reliability: demonstrating that the operations of a study -- such as the data collection procedures -- can be repeated, with the same results (Kidder, 1981, pp. 7-8, cited in Yin, 1989, pp. 40-41).

To satisfy these tests, Yin (1989) suggests the following tactics:

Construct Validity: use multiple sources of evidence; establish chain of evidence; and, 
have key informants review drafts of the case study review;

Internal Validity: do pattern natching; do explanation-building; and, do time-series analysis (not used for descriptive case studies);

External Validity: use replication logic in multiple case studies; and,

Reliability: use case study protocol (Yin, 1989 , p. 41).

The construct validity test was met in this research by using multiple sources of information, including the assessment survey results in the first stage, protocol survey results in the second stage, and triangulation (Guba 1967) with official documentation, such as college catalogs and brochures.

The internal validity test is not, according to Yin and others, used for descriptive case studies when causal relationships are not sought. The test is to keep inferences to a minimum, which descriptive case studies by their internal logic escape.

The external validity test is determining whether or not a study's findings are generalizable beyond the immediate case. When a multiple case study, such as this one, occurs the test is validated by comparative analysis and replication logic within the numerous cases. Descriptive case studies are limited in their generalizations by the logic employed in the internal validity test stated above. 
Yin (1989) was so concerned about the criticism over the external validity issue that he went to some lengths to guide the researcher:

The external validity problem has been a major barrier in doing case studies. Critics typically state that single cases offer a poor basis for generalizing. However, such critics are implicitly contrasting the situation to survey research where a "sample" (if selected correctly) readily generalizes to a larger universe. The analogy to samples and universes is incorrect when dealing with case studies. This is because survey research relies on statistical generalization, whereas case studies...rely on analytical generalizations (p. 43).

Thus, to mitigate criticism of this case study, a descriptive multiple case study approach was selected for this research.

The test for reliability is when a study can be replicated with similar findings and conclusions. Again, Yin (1989) states:

The objective (of the reliability test) is to be sure that, if a later investigator followed the same procedures as described by an earlier investigator and conducted the same case study all over again, the later investigator should arrive at the same findings and conclusions... The goal of reliability is to minimize the errors and biases in a study. (p. 45).

Other researchers following similar case study data based on international education in selected community colleges, using the same documents, and the same survey instruments should have similar results. 
The major tool for ensuring a high degree of reliability is the use of "the case study protocol" (Yin 1989, p. 70). The protocol should have the following sections:

(a) overview of the case study project (project objectives and auspices, case study issues, and relevant readings about the topic being investigated);

(b) field procedures (credentials and access to the case study "sites," general sources of information, and procedural reminders);

(c) case study questions (the specific questions that the case study investigator must keep in mind in collecting data, "table shells" for specific arrays of data, and the potential sources of information for answering each question); and,

(d) guide for the case study report (outline, format for the narrative, and specification of any bibliographic information and other documentation). (p. 70.)

The search for three most active international education programs from the oregon and washington public community colleges started with the results from the first survey instrument. The community colleges with the highest point tally (see discussion above) were identified. College catalogs, state statistics and telephone inquiries were used to confirm the information acquired from the survey results. At least one college was selected from the two state region.

A preliminary protocol (see Appendix F) was established using the general guidelines from Earl Backman's work, Approaches to International Education (1984), and from the research questions, the study propositions, the survey re- 
sults, confirmation inquiries, and documentation obtained. The preliminary protocol guided this study throughout the case analysis.

Yin $(1989$, p. 88) argues that "one of the most important sources of case study information is the interview." Since the survey questionnaire was sent to every community college president, the starting point at each of the site visitations was with the president as a key informant. other key informants were identified from the interviews with the presidents and from personal contacts as a result of the authors twenty plus years in the community college movement. Site visitations were conducted in late March and early April of 1991. At least two full days were devoted to interviewing key personnel on each campus. Every initial face to face interview was tape recorded in order to verify any notes taken during the interviews. Several people were interviewed more than once as information was obtained requiring a reaffirmation. Most of the follow-ups were done by telephone.

The "semistructured" interviews (Merriam 1988, p. 74) commenced by sharing with the key informants the protocol questions that would be used in the analysis of the interviews. While following the written protocol, the case study interviews were at the same time left open-ended in order to allow the key informants to tell of anything that might have 
contributed to the development, evolution, and practice of their international education programs, including leads to other key participants.

The research continued with direct observations at each of the sites in order to examine first hand those "relevant behaviors or environmental conditions" that may have given rise and sustenance to a successful international education program (Yin 1989, p. 91). Sharan Merriam (1988, p. 90) argues that at least three factors should be taken into account when observing a case site: The setting; the participants; and the activities and interactions.

This research also followed closely Yin's (1989) three principles of data collection: Using multiple sources of evidence; creating a data base; and, maintaining a chain of evidence (pp. 95-102). The protocol concept and the principles of data collection designed for the case study research detailed by Robert Yin (1989) was adhered to at every step of the investigation in order to minimize any criticism of the approach or of the analysis.

\section{SUMMARY}

The reason for choosing survey questionnaire and the descriptive multiple case study research designs was both to describe the current status of international education at the public community colleges of oregon and Washington and 
to describe in-depth the implementation, evolution, organization, operations, and expansion of international education programs at three of the most developed and most active community colleges in the two state region of oregon and Washington. 


\section{CHAPTER IV}

\section{SURVEY QUESTIONNAIRE RESULTS}

In this chapter, the data collected on international education from the public community colleges of oregon and Washington were analyzed and reported through the use of tables, charts, and graphs. The data are further analyzed and reported through the use of descriptive statistics (percentages, means, medians, frequencies, and ranges). The resulting data were analyzed by computer using two applications: PlanPerfect 5.1, a spreadsheet; and, Minitab 1.1, a statistical computer package. Table presentations of the data were created on Wordperfect, version 5.1, while graphs and charts were created on Harvard Graphics, release 2.3.

\section{PURPOSES OF THE SURVEY QUESTIONNAIRE}

There were two primary purposes to be served from the survey questionnaire. The first purpose was to identify and describe the current status of international programs and activities in the community colleges of oregon and Washington states as they existed during the 1989-90 academic year. The second purpose of the survey questionnaire was to quantify, analyze, and interpret the data in such a way as to 
clearly and equitably identify three of the most highly developed community colleges in the field of international education from the two states. Subsequently, these three highly developed community colleges became the subjects of the case studies, which provided a further in-depth analysis of international education practices in the two state region (see Chapter V).

\section{BACKGROUND}

A mailed survey questionnaire was sent to the presidents of the forty-three public community colleges of oregon and Washington states. After four months and numerous follow-ups, thirty-three colleges (77\%) responded. Unfortunately, two of the responses were from presidents indicating that they were not inclined to answer the survey and one response was only partially completed; thus, in reality, only thirty colleges (70\%) are represented in the final results. Eleven oregon community colleges (69\%) and nineteen Washington community colleges (70\%) are represented in this study (see Figure 1 below).

Eight campus presidents out of thirty respondents took the time to fill out the questionnaire. There were six international education administrators, five deans of in struction, two assistants to the dean of instruction, and a variety of others, including one registrar and one ESL 


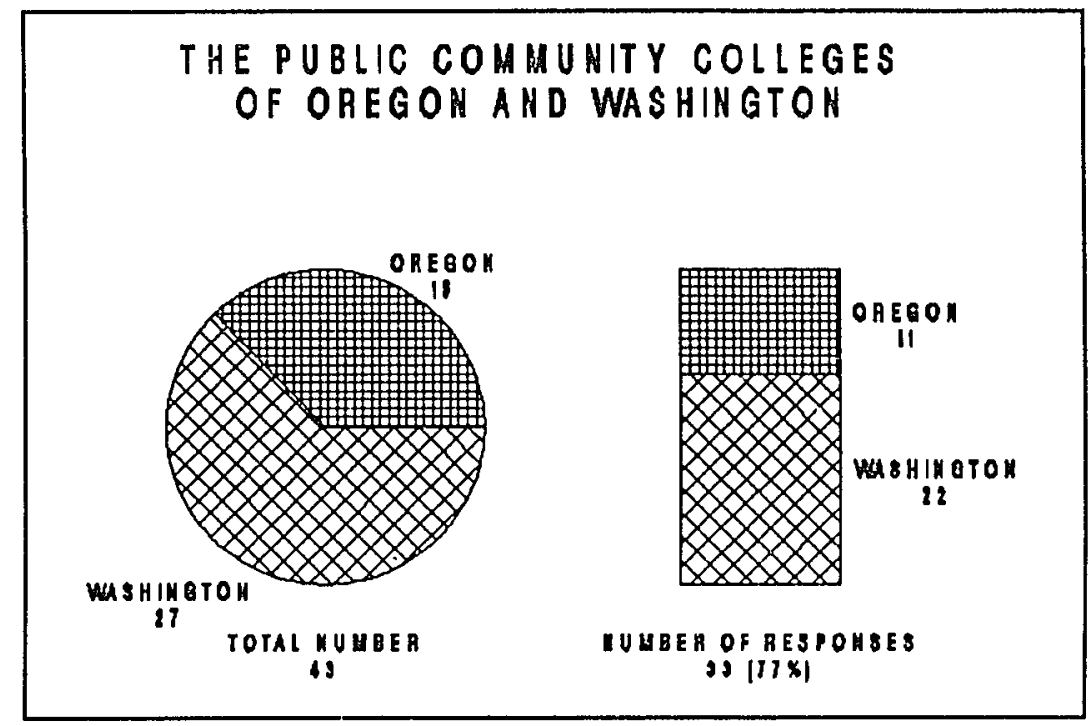

Figure 1. Community College Response Rates.

director who responded to the survey (see Appendix B for a complete list of Oregon and Washington community colleges and the participants in the study).

The community colleges responding to the survey varied greatly in size and structure. The largest, Portland Community college in oregon, had 13,929 full-time equivalent students (SFTE's), while the smallest, oregon coast Community college, had only 100 full-time equivalent students in attendance during the 1989-1990 school year. Interestingly, the range of school sizes was much greater in the oregon community college "system" than that of Washington, which ranged in size between 6,479 for Pierce College as the largest school and 1,183 for Big Bend as the smallest school. (See Figure 2 below.) Twenty-six of the respondents were 
in single campus districts, while four of the respondents were parts of a multi-campus district: North seattle and Seattle Central in the three campus Seattle Community Col-

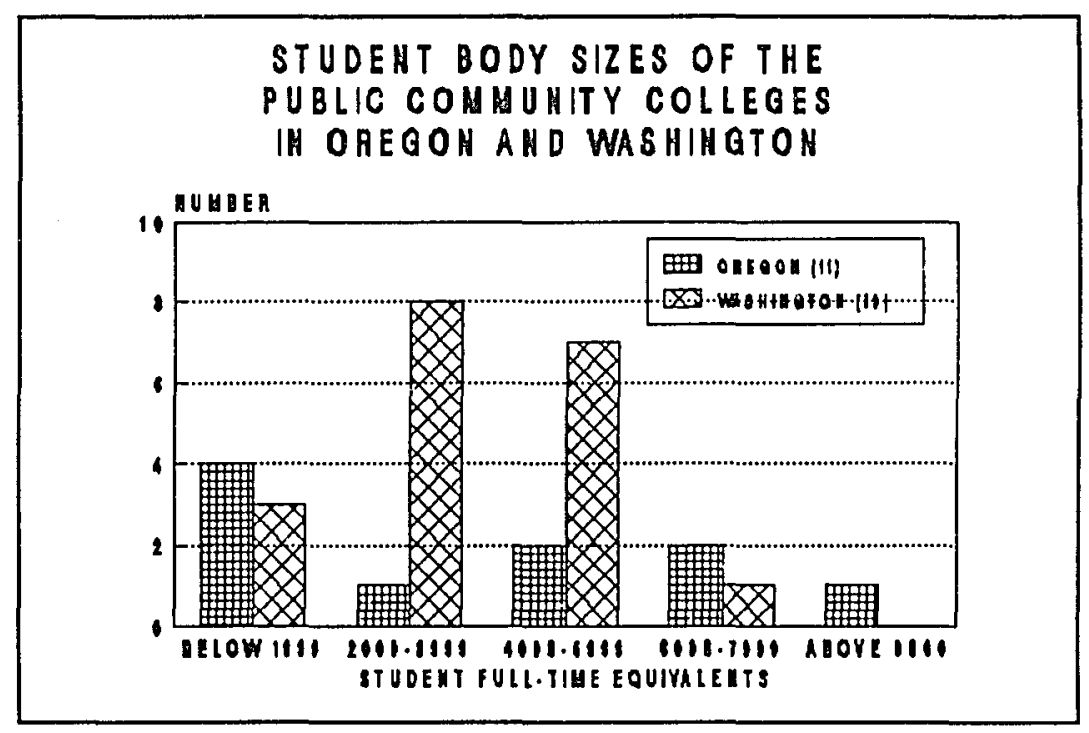

Fiqure 2. Student Body Size By FTE's.

lege District (Seattle South did not respond); and, Spokane Falls and Spokane Community College in the two campus Community Colleges of Spokane District. Portland Community College, it should be noted, which has three large, separate campuses, responded as just one entity.

The mean campus size in the two state region amongst the respondents was 3,980 full-time equivalent students, the median was 3,547 , and the trimmed mean (eliminating the top and bottom five percent) was 3,702 . The mean campus size for oregon respondents was 4,615, while the mean for Washington respondents was 3,612 . 
From the literature and the data generated in this study, it is fair to suggest that international education is not one of the highest priorities of the community colleges, either at the national level or in the oregon and Washington state region. The thirty respondents, when asked to rank international education from lowest priority to highest priority on a five point scale, ranked, on average, slightly more than a middle priority with a score of 2.867 . No community college ranked international education as the highest priority, although eight schools placed international education in the high middle of priorities. Fifteen campuses see it as a middle priority. Five more said international education was a low middle, and two said it was

\section{INTERNATIOHAL EDUCATIOH AS A PAIORITY}

OF OREGON AHD WASHINGTON COHHUNITY COLLEGES

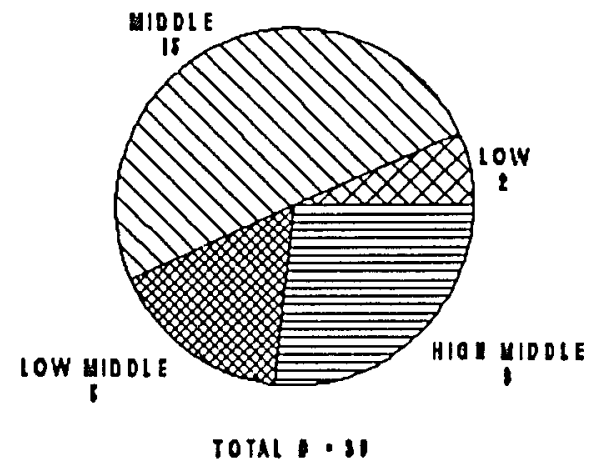

Figure 3. International Education Priority 
amongst the lowest priorities for their schools. Nevertheless, it was interesting to learn that there is, indeed, quite a bit of international activity taking place in the region's community colleges.

THE STATUS OF INTERNATIONAI EDUCATTON

The survey questionnaire results were analyzed in the context of the new taxonomy on international education (see Chapters II and III). The taxonomy, it will be recalled, was created to better understand the meaning and definition of international programs and activities as they are actually practiced. Each dimension or element in the taxonomy can reveal the extent to which the public community colleges of Oregon and washington states are engaged in this field.

\section{Recruitment and Education of International students}

The first dimension within the taxonomy of the meaning and definition of international education in the community colleges is that of recruitment and education of international students. The data from the thirty schools in oregon and Washington revealed there were 2,463 full-time international students in attendance in 1989-1990. The greatest number of full-time international students were attending Edmonds Community College with 450, which was exactly ten percent of their student body, followed by Shoreline community College with 290. Big Bend, Lane, Portland, Tacoma, 
Chemeketa, North Seattle, and clark all had more than 100 international students in attendance during the same time period. Several schools reported no international students attended their institutions. Figure 4 below shows the six most active community colleges in terms of international student enrollments.

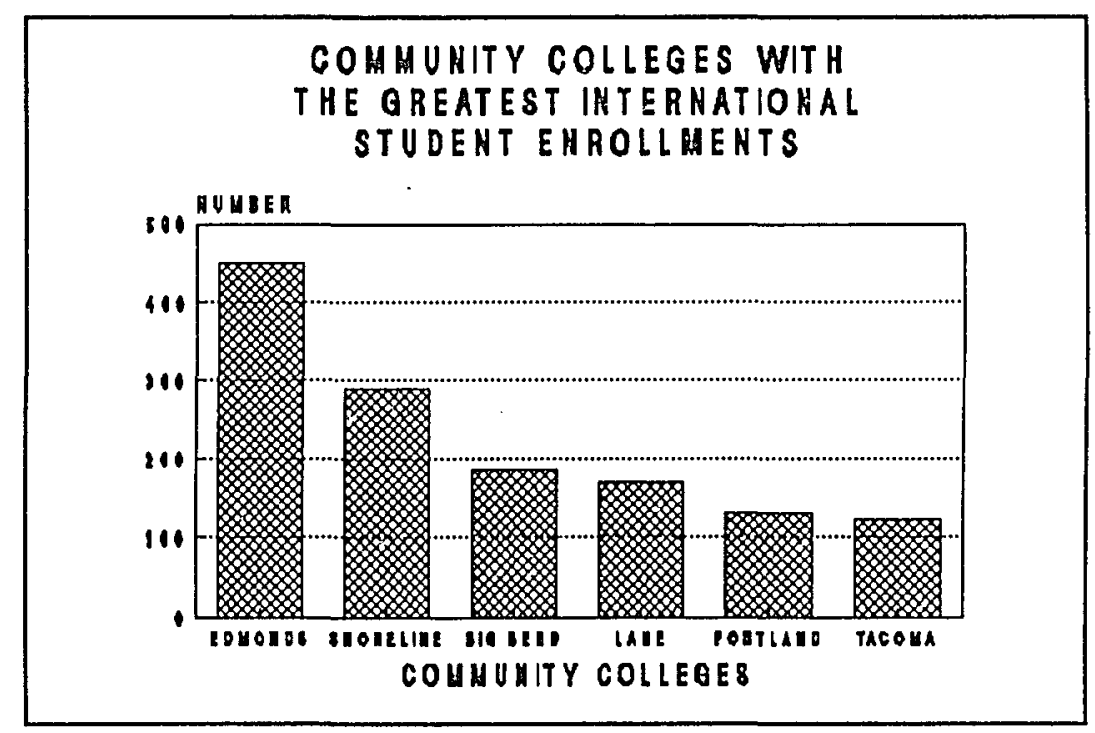

Figure 4. International student Enrollments.

The school with the largest percentage of international students was Big Bend Community College, a small rural campus in the eastern part of Washington state, which had 160 international students or $15.83 \%$ of its student body. Figure 5 below shows the percentage of international student enrollment to full-time student equivalents among the six most active community colleges in oregon and washington. Yet, Big Bend Community College with the largest per- 
centage of international students to the rest of the student body listed only one international student advisor with a work load of only ten percent of his or her time. Upon further investigation, it turns out that Big Bend had a large contingency of Japanese agricultural students who were studying under a Japanese government contract on the former US Air Force Base, which is today the main campus of Big Bend Community college. These students required no academic advising provided by the college inasmuch as they were in a self-contained program.

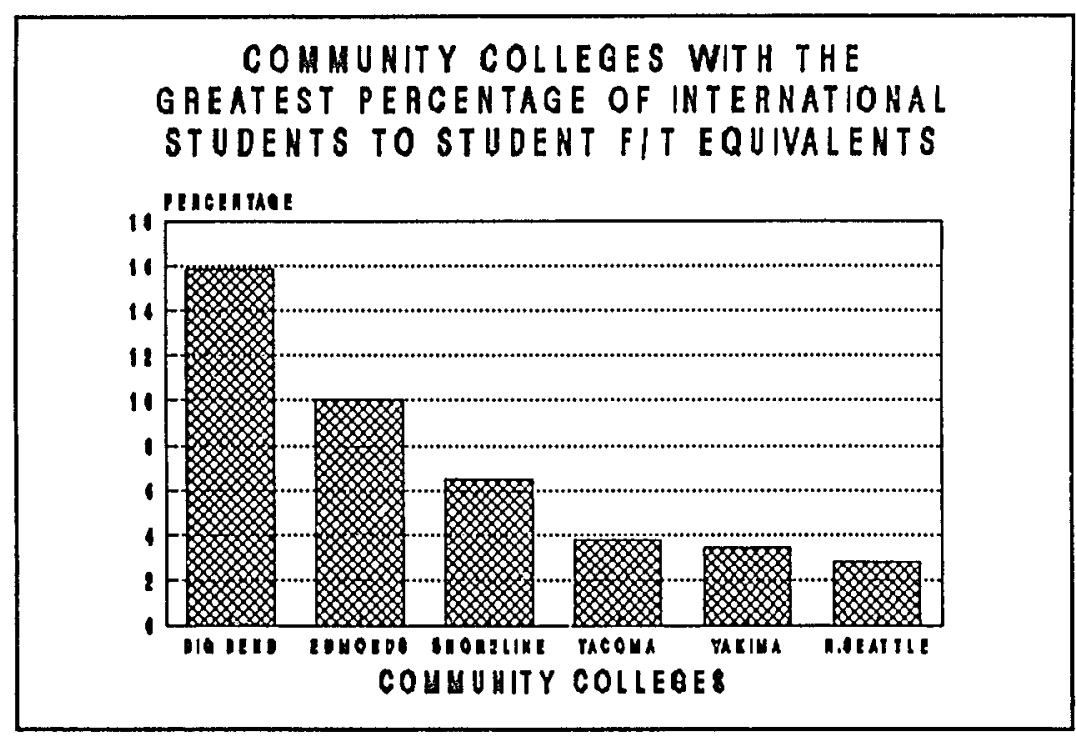

Figure 5. International students to FTE's.

other campuses, of course, employ international student advisors according to the needs of their campuses. The survey data showed that there were 17.3 fte international student advisors for the thirty campuses, which translated 
into approximately one half-time person for each of the schools surveyed. Furthermore, by dividing the 17.3 international student advisors among the 2,463 international students at the thirty schools, there was a ratio of only one advisor for every 142.36 students. Considering the attention most international students need in adjusting to both a new campus and a new country, the oregon and Washington community colleges are probably understaffed and not doing an adequate job of supporting their international students.

The eleven Oregon community colleges in the study reported only 3.35 full-time equivalent international student advisors. The same eleven community colleges reported 621 international students for a ratio of 185 international students for every full-time advisor. Washington community colleges have a ratio of one international student advisor for every 132 international students. The Washington community colleges clearly are giving more attention to their international student body.

An integral aspect of this dimension of the taxonomy includes the recruitment of international students. Fifteen of the thirty schools reported that they actively recruit international students; thus, exactly one-half of the community colleges in the study do not actively recruit international students. Only two of the eleven oregon community 
colleges (18\%) recruit international students, while thirteen of the Washington community colleges (76\%) actively pursue a diversified student body containing international students. Some larger schools, such as North Seattle with 120 international students, Lane with 173, clark with 100, and chemeketa with 125 , even without active recruitment, have been successful in drawing international students for reasons that seem to go beyond active recruiting. Chemeketa Community College, which does not actively recruit and does not provide student advising beyond 10 percent of one counselor's time, is for unknown reasons to this author still able to attract significant numbers of international students.

The retention of international students was examined through the category of percentage of degrees awarded. While the national average for Associate of Arts degrees granted is only about ten percent (Parnell, 1985), one indicator of international student retention is the completion of the Associate Degree. This study asked the respondents to estimate the percentage of awarded degrees for international students.

The survey results indicate a much higher than average completion rate for international students than for native students when looking at national averages. In the two state region, it is estimated by the respondents that forty- 
five percent of the 2,463 international students will receive a two-year degree $(1,100$ students) by the time they complete their stay on campus. As Figure 6 shows, slightly more than sixty percent of all international students were in transfer studies, while slightly less than 40 percent were in technical training.

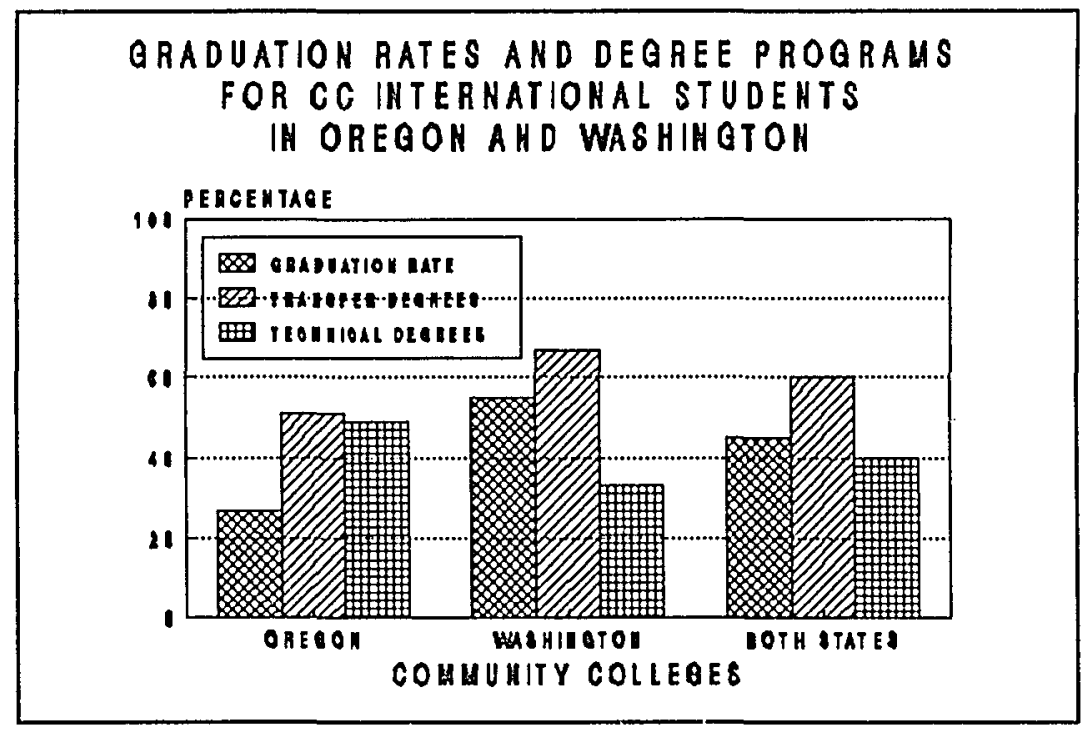

Fiqure 6. International student Degrees.

Seven schools, with an international student population of 151, reported no students will graduate. On the other hand, two schools, with an international student population of 6 , reported that all will graduate.

International students attending washington community colleges did have a higher graduation rate than their counterparts at the oregon community colleges. Oregon community colleges estimate that only $26.8 \%$ of their international 
students will graduate, while $55.8 \%$ will graduate from Washington community colleges. It should be noted, too, that international students attending Washington community colleges were more likely to be enrolled in a transfer program (67.4\%) than their counterparts in oregon, where more than half $(50.5 \%)$ are enrolled in a vocational/technical two-year program.

The countries of origin of the international students are unknown from this study. It would be, however, very informative to know the countries of origin to better understand why only one-third of Washington's international student body are enrolled in vocational/technical training while one-half of Oregon's international student body is enrolled in two-year programs that may, or may not, have immediate impacts on the development strategies needed in other parts of the world, especially in the "third world." In other words, are the community colleges of oregon and Washington attracting two completely different types of international students, one from the more developed world and the other from the less developed world?

Another aspect of international students that was examined in the context of the first dimension of the taxonomy was English as a second Language training. This study discovered that ESL training is provided by nearly all community colleges in oregon and Washington states to any 
person whose native language is other than English (97\%). ENL, English as a Non-native Language, is a relatively new phenomenon that offers English language training at the lower division transfer level (much like Spanish, German, and French) and is closely allied with the teaching faculty of ESL. ENL is currently offered by 14 of the community colleges surveyed $(47 \%)$, with eight washington campuses (42\%) and six oregon campuses (55\%) involved. ESL training is often provided free of charge to the student through community service classes, while ENL is offered through the regular class schedules.

Both international students who arrive on student visas to pursue one or more years of training in the United states and those students, who for a variety of reasons do not speak English, attend local community colleges in pursuit of English language training. The two categories of students often-times end up sharing the same teacher and the same classroom combining to enlarge the overall "international" presence of any given community college campus.

This study revealed that there were 11,795 students enrolled in ESL and ENL during the 1989-90 school year at the Oregon and Washington community colleges surveyed. The mean was 421.3 students for the thirty community colleges and the median was 212 . The range was a low of 30 and a high of 1,850. Figure 7 shows the six community colleges 
with the greatest ESL \& ENL enrollments. Central seattle Community college had the highest enrollment with 1,850

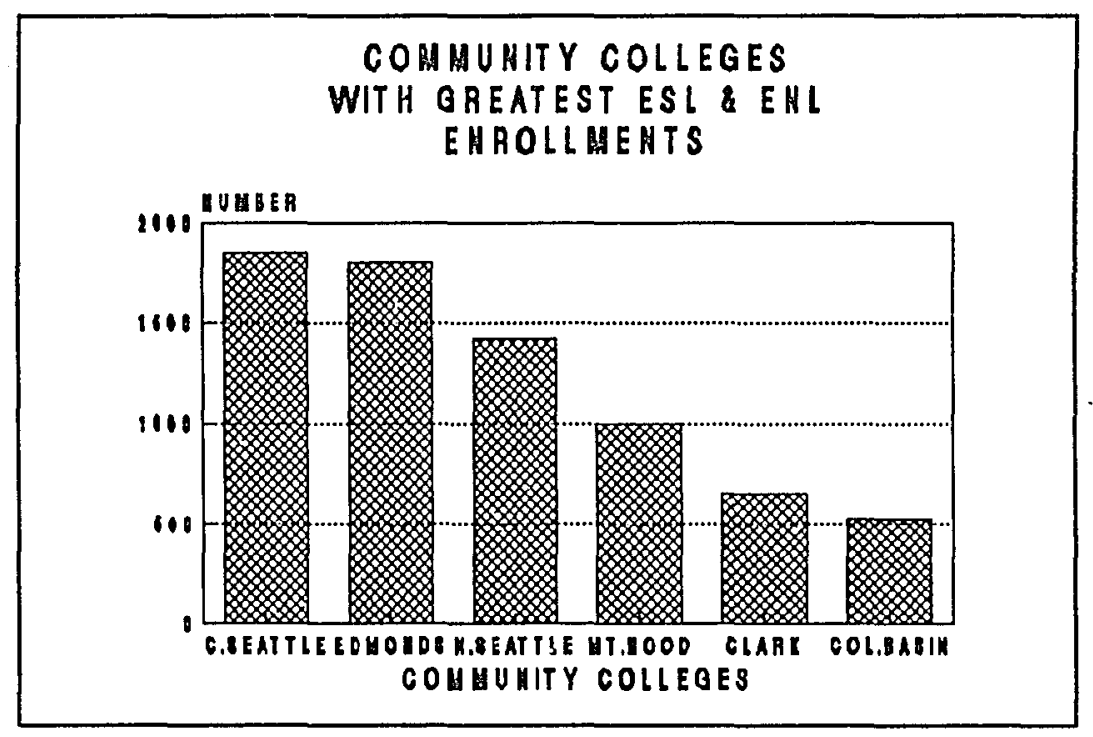

Figure 7. Enrolled ESL and ENL Students.

students, with Edmonds Community college enrolling an additional 1,800 ESL/ENL students. North seattle community College, in the meanwhile, enrolled 1,450 ESL/ENL. Mt. Hood, Clark, and Columbia Basin Community Colleges all enrolled between 500 and 1,000 ESL/ENL students during the 1989-90 academic year. Unfortunately, this study did not include in its original goals to ascertain exactly how many of the ESL/ENL students are, in fact, international students. It is clear from discussions with both ESL instructors and international education administrators, however, that some percentage of the ESL/ENL student body comes from the international students attending a particular community 
college.

An examination of the responses indicated that the highest percentage of ESL students in relationship to student full-time equivalents occurred at North Seattle Community college, where 6.8 percent of the student body was enrolled in ESL classes (see Figure 8 below). Edmonds and Central seattle were each above six percent, Wenatchee was above four percent, and Central oregon and Mt. Hood were above three percent each. The mean percentage for the

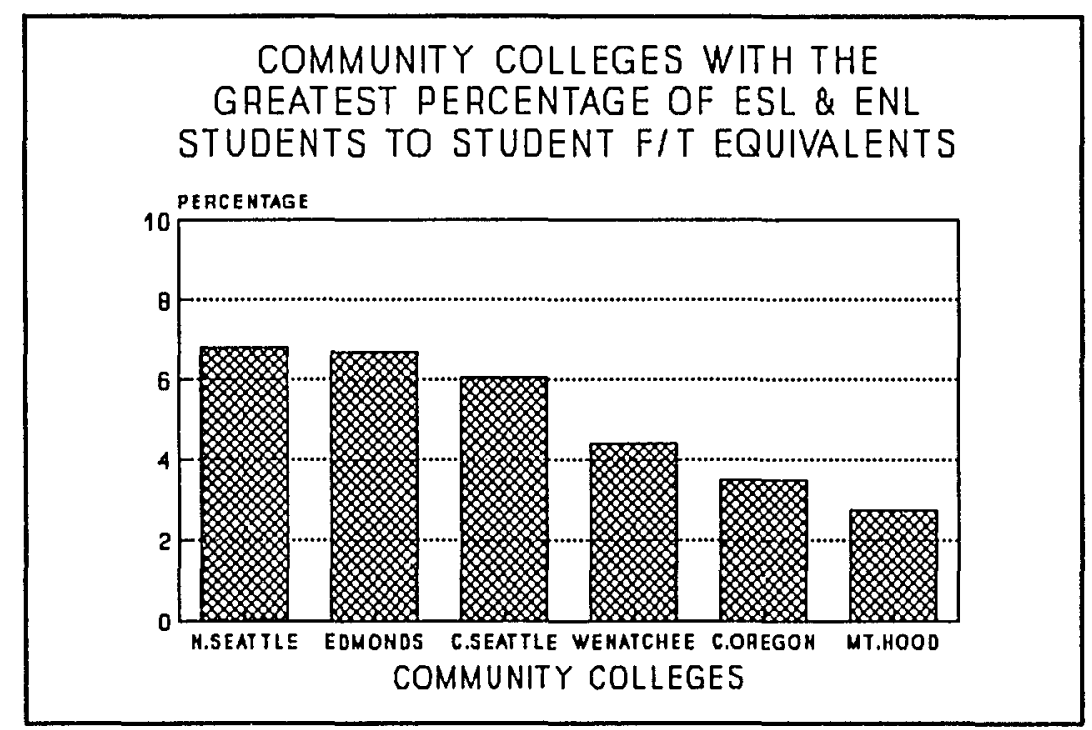

Figure 8. ESL and ENL students to FTE's.

thirty community colleges was 2.85 percent, while the median was 2.1 percent. (An academic anomaly did occur when oregon Coast Community College reported that with 100 student fte's that they had 25 percent of their students enrolled in ESL classes.) 
Foreign Born Faculty

Another indication of the "internationalization" of a community college can be found in the second dimension of the taxonomy in the number of foreign born full-time faculty on any given campus. While the literature was virtually silent on the demographics and contributions of foreign born faculty to higher education and specifically to international education programs, this study found 164 foreign born faculty members among the 3,763 faculty on the thirty campuses surveyed. There were 123 foreign born full-time faculty in washington state and 45 in oregon. This represents 4.4 percent of the total full-time faculty in the two state region. Foreign born faculty represented 5.7 percent of the total faculty in Washington state, while only 2.7 percent were accounted for in oregon. There was a mean number of 5.5 foreign born faculty for each of the thirty campuses, while the median number was 4 for the two state region. Oregon had an average of only 4.09 for each of the eleven schools responding, while Washington had an average of 6.47 for each of the nineteen schools in the study. Shoreline Community college had the highest percentage of foreign born faculty with thirty on their staff representing twenty percent of the total faculty. Seattle central had 23 foreign born faculty, which is 18.7 percent, while Tacoma and Yakima had ten each. Mt. Hood had six, or 
3.31 percent. Figure 9 shows those community colleges with the highest percentage of foreign born full-time faculty to full-time faculty in oregon and Washington.

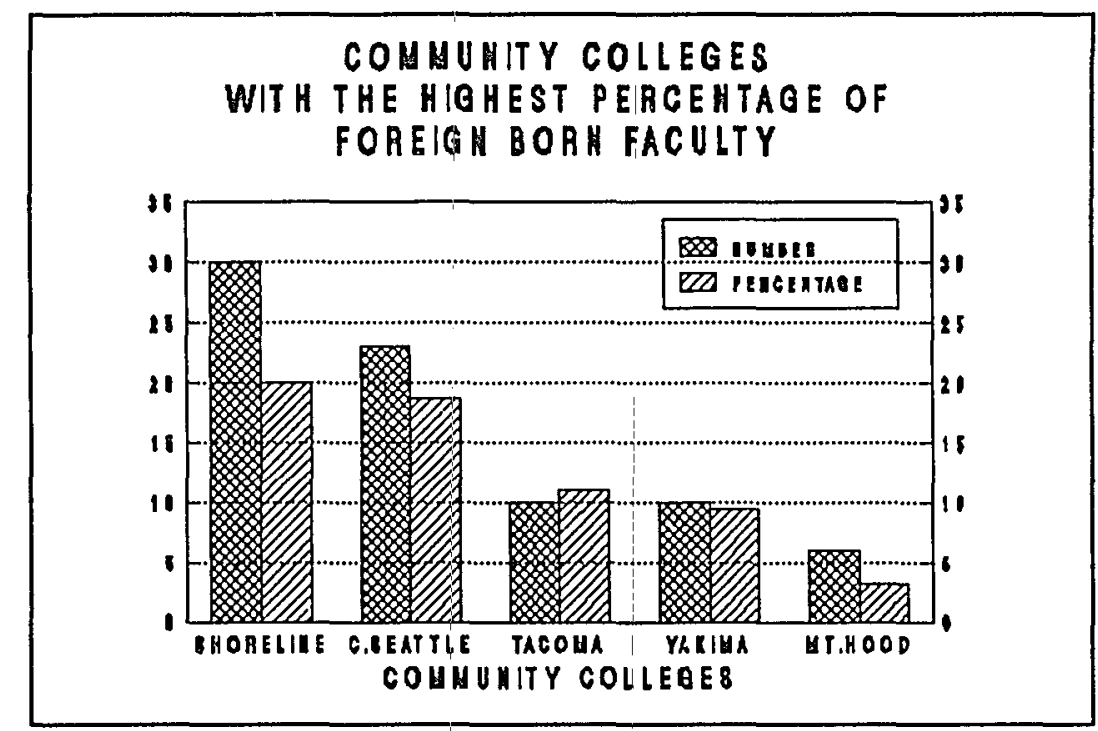

Figure 9. Percentage of Foreign Born Faculty.

\section{Non-US Curriculum}

The third dimension of the taxonomy in this study is related to the level of instruction in courses devoted to subject matter that generally does not use the United states at its core. This category included foreign language study and courses on the history, culture, politics, and economics of other nations.

All of the responding community colleges offer foreign language training in at least two languages other than English (see Figure 10 below). The Isurvey revealed twelve different Ianguages -- Chinese, Dutch, French, German, 
Italian, Japanese, Korean, Latin, Norwegian, Russian, Spanish, and Swedish -- are taught in the thirty community colleges in the two state region.

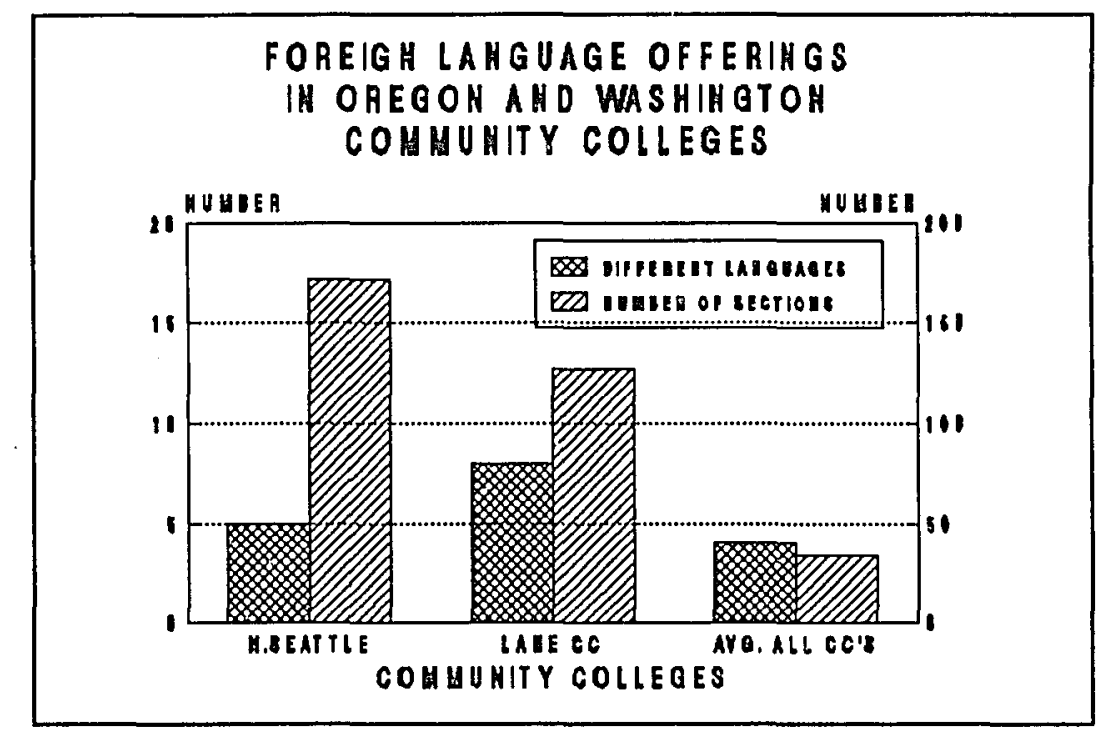

Figure 10. Different Languages and sections.

Lane Community College was the most active foreign language school and teaches eight different languages. North Seattle Community college, on the other hand, offered the most foreign language sections with 171, although only offering five different foreign languages during the school year 1989-90. The mean number of different foreign languages at the thirty responding community colleges was 4.13 , while the median number was 4 . The twelve different languages generated a total of 1,110 sections for the thirty schools during 1989-90. The average number of foreign language sections taught equaled 38, while the median number 
was 29 .

Spanish language training is by far the most popular foreign language and all responding community colleges teach it with the exception of clatsop Community college in Astoria, Oregon (Figure 11). There are more Spanish language sections than any other foreign language offerings,

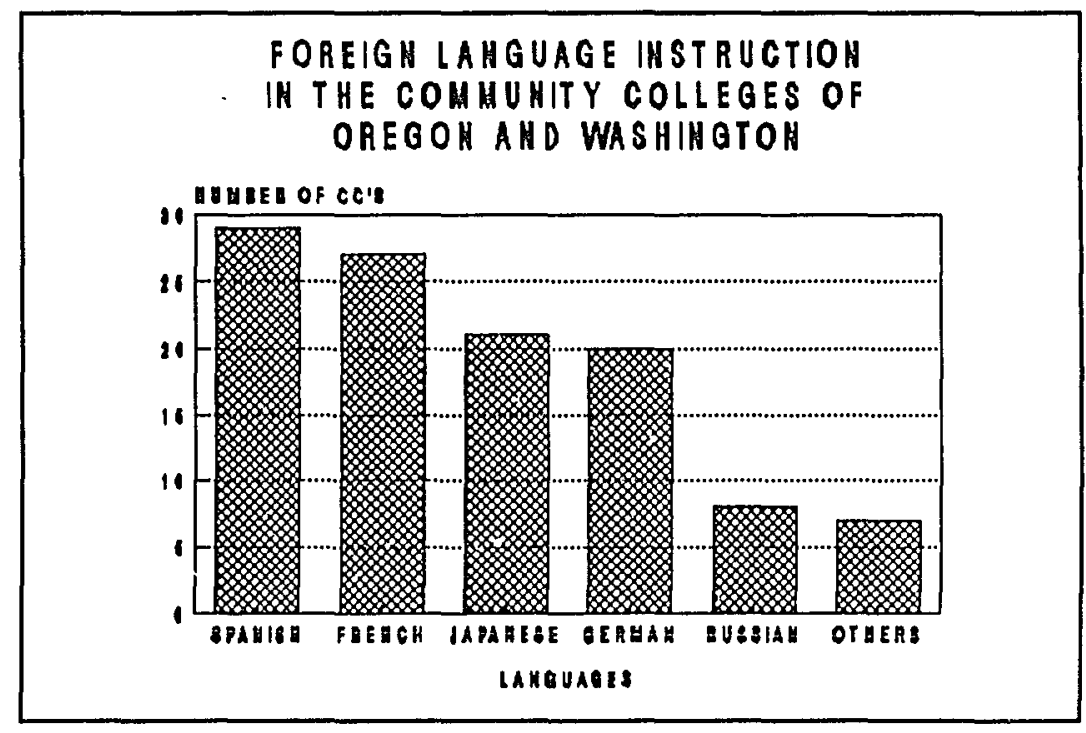

Figure 11. Foreign Language Instruction.

too. French language training was second with twenty-seven schools offering it.

From the survey data, it was found that 21 community colleges now offer Japanese language training, while only 20 offer German language training, once considered the number one foreign language of choice, especially for scientists and engineers in the United states. The obvious explanation for this change is due to the presence of Japanese business- 
es in the United States and the location of oregon and Washington in the Pacific Rim with closer ties to Japan than most other states. The pattern seems established and the future of Japanese language classes seems secure. Not so secure, perhaps, are the many other language classes offered as one-time courses to please a relatively small constituency, such as Latin or Norwegian or Italian. The data revealed Russian was being taught at nine different community colleges, and that chiese was being taught at eight different community colleges in the Northwest. The third dimension of the international education programming survey dealt also with the types and varieties of courses devoted to subject matter not tied directly with a curriculum base for the United States. This open-ended, perhaps poorly worded, question seemed to tax the imagination of the respondents as to what exactly was being asked of them. The answers were often-times uninspired, and they seemed to lack an in-depth understanding of their own curriculum, college catalog and class schedule. As a result, the responses are somewhat suspect for specific meaning in the search for those Pacific Northwest community colleges involved in international education. Yet, it would be remiss not to report on several of the more interesting aspects of the responses.

The thirty respondents found a total of 129 classes 
related to a cultural curriculum not rooted in the United states. The mean number of responses for both states was 4.45 courses or classes per college, while the median was 3.0 and the range was from 0 to a maximum of 20 . Among the nineteen Washington community colleges, they offer 83 such courses for an average of 4.36 classes per campus. Among the eleven Oregon community colleges, they offer 46 such classes for an average of 4.18 classes per campus.

Several respondents marked down| "none" on their answer sheets leaving it unknown as to whether or not they saw the question and merely skipped over it due to the open-endness or the amount of time they might have to take to fill i.t out fully. Many of the schools did list their Western or World Civilization courses; although, many, who do, in fact, teach the sequence in Western or World Civilization, did not. One school listed as their entire non-US|based curriculum their one course on World Religions. Several listed their Geography courses. Several more listed $\mid$ stand alone history classes, such as The History of Japan or The History of China as their sole entries. One school listed several music classes, including Music cultures of the World. Several listed all of their Anthropology classes. And, three schools sent pages from their catalogs marked with international education entries.

Figure 12 shows that based on responses to this survey 
item, Mt. Hood, Tacoma, North Seattle, Portland, Shoreline and spokane Falls community colleges are among the most active schools devoting classes to international education from a non-Us based curricula.

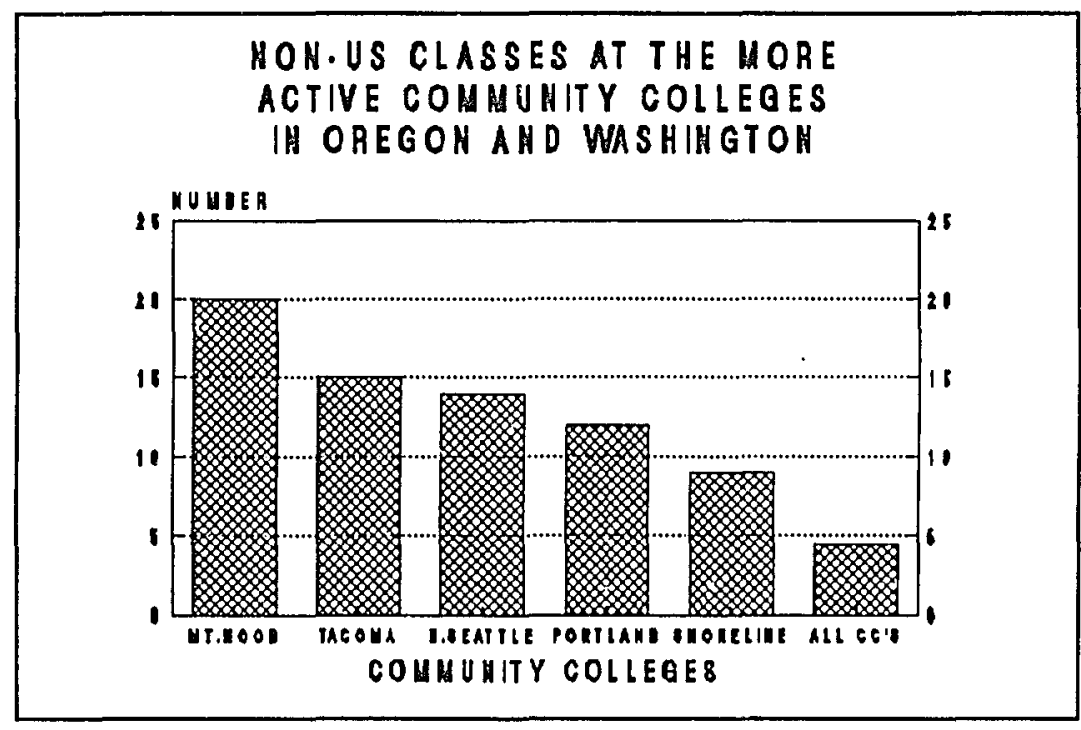

Fiqure 12. Non-US Classes.

\section{Internationalizing the curriculum}

The fourth dimension in the taxonomy is an examination of the extent to which the oregon and Washington community colleges have attempted to "internationalize" their existing curricula. Proponents of "internationalizing the curriculum" suggest that community colleges should infuse into existing courses materials on other cultures, other nations, and other practices found in the global community. In addition, proponents suggest that efforts should be made to create specialty courses detailing the rise of "internation- 
alism" in contemporary affairs. These courses, usually called International studies or International Education, are stand alone classes designed to introduce the student to the world without reference to a specific national culture, but focus on global issues.

"Internationalizing the curriculum" was not only to strengthen existing traditional non-us curriculum but to infuse those ideas found in other cultures into the traditional American-based curriculum. The intent of instructors and administrators promoting this process was to introduce new materials for existing courses in the curriculum.

The main enterprise found in "internationalizing the curriculum" focused on the writing of modules or components that could be adapted to any existing course depending on the imagination and creativity of the course instructor. The module or lesson plan approach to "internationalizing the curriculum" has, indeed, been followed by a number of community colleges in oregon and Washington.

only two questions were asked of the respondents: One, has your college implemented a program generically known as "internationalizing the curriculum?" And, two, what date (or year) did you begin this process?

Thirteen community colleges $(43 \%)$ in the two state region have programs for implementing an "internationalization of the curriculum," while seventeen community colleges 
(57\%) did not. Five out of oregon's eleven responding schools (45\%) are involved, and eight out of Washington's nineteen responding schools (42\%) are also involved. Shoreline Community college reported that they have been "internationalizing the curriculum" since 1975 or for the past fifteen years. The mean number of years for all thirty schools was 2.7 years, while the mean for the thirteen actively engaged schools was 6.23 years. Although Shoreline has been at it the longest, the washington state community colleges who recognize the value of "internationalizing the curriculum" are relatively new in this arena with a mean of only 3.1 years. The oregon state community colleges who have been involved in this aspect of international education have been at it longer with a mean of 8.2 years. Mt. Hood Community college, which has been recognized nationally for its efforts in "internationalizing the curriculum" (AACJC Journal, Aug./Sept. 1990), has been involved since 1978 .

\section{International Trade and Business Education}

International trade and business issues continue to grow in importance for the United States, each individual state in the union, and for local communities. In order to probe the level of international trade and business activities at the community colleges of oregon and Washington, three responses were solicited: Do you offer specific 
courses designated with the title, "International," what are they, and how many of each did you offer in the 1989-90 academic year?

Santiago wood (1986) surveyed ninety California community colleges (out of 106) and discerned that only sixteen (18f) said they had offered classes or programs in international trade and business, while only two (4.5\%) required international trade or business courses for their business majors, and no community college in california required a course in international education for completing an Associate of Arts degree (p. 95). In the 1984 nation-wide study by Vassilou, she discovered that only 60 (14\%) of the 432 responding community colleges offered any formal course work or programs related to international business. The two studies pointed out that very few community colleges were engaged in international trade and business activities at a time when international trade and business was on the rise. The results of this study indicate that seven of the eleven responding oregon campuses $(64 \%)$ and ten of the nineteen responding Washington campuses (53\%) offered courses labelled "International." Figure 13 reveals that when specifically asked to identify courses being offered as International Business, oregon community colleges with twenty-seven percent and Washington community colleges with thirty-eight percent, exceeded both California and the rest 
of the nation in the percentage of schools engaged in international business education with ten schools reporting that

\section{THE PERCEHTAGE OF COHHUHITY COLLEQES OFFERING IHTERNATIOHAL BUSIHESS AAD TRADE COURSES}

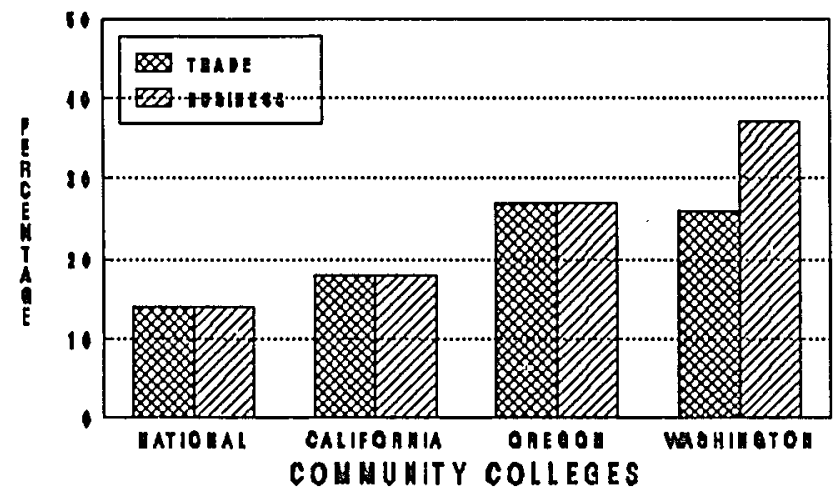

Figure 13. Business and Trade Courses.

they offer such courses. When specifically asked to identify courses being offered as International Trade, oregon (27\%) and Washington (26\%) again exceeded the findings of Wood (1986) and Vassilou (1984) with eight schools responding that they offer such courses.

Three schools offered International Education courses at least once, and four schools offered International Economics at least once during the 1989-90 school year. International Law, a very specific course usually taught at the upper division or graduate school level, was being taught at two different community colleges in the region to enhance their International Business and Trade programs. 
Two community colleges in the region, North Seattle Community College and spokane Falls community college, received grants from the Us Department of Education under the Title VI(b), International Business Education Program, totalling more than $\$ 200,000$ in $1989-90$.

In seven different categories of international course offerings, the region's community colleges engage in them all to a greater or lesser extent. The mean number of international course offerings was 1.67 for the entire responding group (see Figure 14). The thirty responding community colleges offered 113 sections of instruction in these seven different class offerings. The mean number of sections was 3.93, with one school, North Seattle, offering 22 sections. Mt. Hood offered six different classes and 12

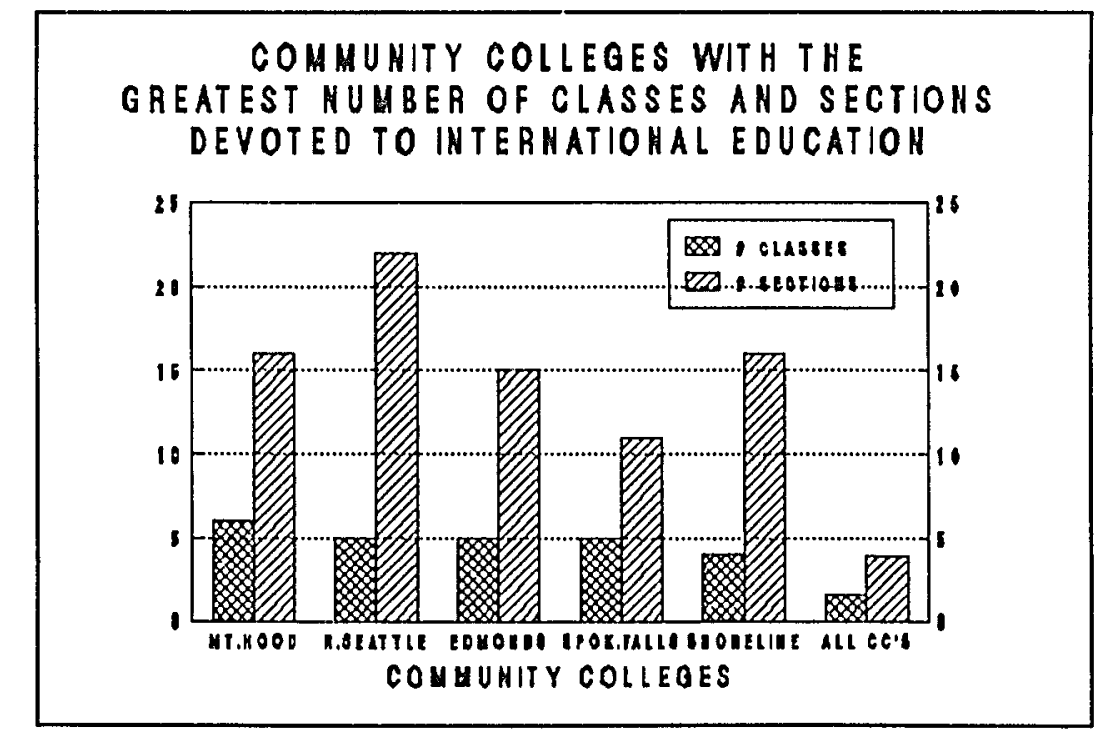

Figure 14. International Education Classes. 
sections, while Edmonds, Spokane Falls, and North Seattle Community Colleges with five different classes each.

While advocates of international education, especially in the business and trade area, argue for a greater offering of classes and courses to better prepare today's students for the world of tomorrow, oregon and washington community colleges appear to be doing a better job in these two states than what was true in California or in the nation as a whole just five years ago. only a national study could confirm this particular supposition.

\section{"Sister College" Relationships}

The sixth dimension in the taxonomy of international education programming for a community college is the involvement with other colleges and universities in other countries around the world. This involvement can help create an atmosphere of openness to new ways of conducting educational services and a sharing between peoples of different cultures and backgrounds.

The lack of a solid literature and research base precluded any indication of what might be expected in this arena. However, eleven out of the thirty responding Oregon and Washington community colleges (37.6\%) had one or more "sister college" relationships during the 1989-90 academic year. Four schools in oregon (36.3\%) and seven schools in Washington $(36.8 \%)$ reported such relationships. 
Skagit Valley Community College reported three formal "sister college" arrangements. The mean number of relationships among the eleven community colleges reporting this activity was 1.73 , and the median was 1.4 , with a range of 1 to 3. Nineteen community colleges reported no formal "sister college" relationships.

A second part of the one question appearing on the survey instrument asked the respondents to list the "sister college" by name and location. Not surprising, the eleven reporting community colleges had thirteen such arrangements

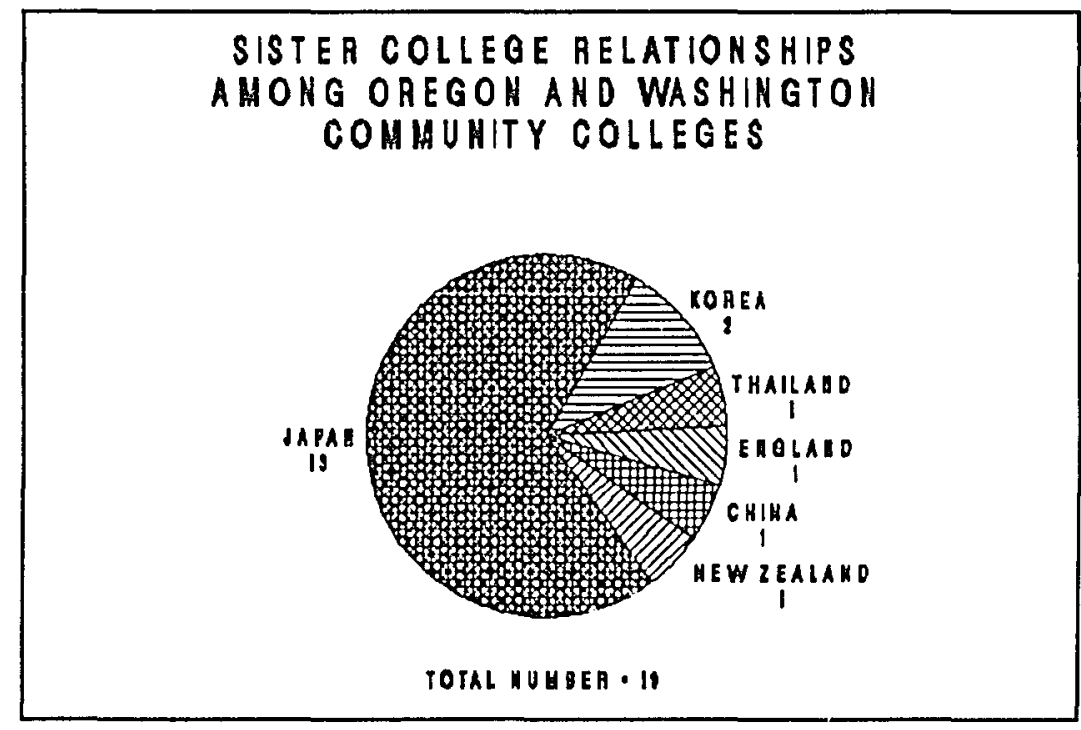

Figure 15. Sister College Relationships.

with Japanese educational institutions. This has probably come about due to the emphasis placed on "Pacific Rin" issues and the obvious Japanese presence in all aspects of life in the Pacific Northwest. 
Shoreline community college reported that they have a "sister college" located in Kobe, Japan, also site of the Edmonds Community College branch campus in Japan. Thus, they are still competing for students (their districts are nearly side by side in north seattle and king county) on the other side of the Pacific Ocean. Edmonds reported two "sister college" relationships, both in Japan, and Mt. Hood had one "sister college" in Japan and another in Korea. A second community college, Pierce, has a "sister college" relationship in Korea. Great Britain, Thailand, China, and New Zealand are the locations for the remaining "sister college" relationships.

\section{Community Colleges Abroad}

The seventh dimension in the taxonomy is the establishment of community colleges abroad. While there is very little literature available on this practice, there are across the United states a few community colleges actively engaged in either assisting other nations in the development of their own community colleges or in operating branch campuses in other nations. The lack of a literature and research base precluded any expectations of what might be found in the community colleges of oregon and Washington in this area of international education.

The survey questionnaire administered to the oregon and Washington community colleges attempted to shed some light 
on whether or not they were involved in a) assisting a host government or school in a foreign country in the development of a community college or b) operating their own branch campuses abroad.

of the thirty schools responding, six schools were involved in either activity. (Green River Community College, which has been reported in the press as being involved in the operation of a branch campus in Japan during the 1989-90 academic year, did not respond to this survey even after three letters, the sending of a second survey instrument, and no less than eight phone calls to top administrators asking for their support and involvement in this research.)

Edmonds, Everett, Lane, and Shoreline community colleges had had requests from other nations to assist in the establishment of two year colleges abroad. Edmonds had contacts from four different countries, Japan, Taiwan, France and Spain for assistance. Everett had contacts from Japan and Costa Rica for assistance, while Lane was contacted by Japanese officials and Shoreline by officials from the People's Republic of China. Thus, six (13\%) of the thirty responding schools were engaged in assisting other nations' development plans for two year colleges. The extent and nature of these plans are unknown due to the limitations of the survey instrument. 
On the question of operating a foreign branch campus, two responding institutions, Edmonds Community college and Mt. Hood Community college, both operate their own branch campuses in Japan: Edmonds in Kobe; and, Mt. Hood in Kurashiki. (see Chapter $V$ for details on these operations.) When asked if their community college was considering opening a foreign branch campus or others, two schools, Edmonds Community College and Big Bend Community College, responded with affirmative answers. Big Bend did not indicate where they were seeking an overseas branch campus. But, Edmonds indicated they were looking at possible branch campuses in three different locations: Taiwan, France, and Spain. The questionnaire was unable to ascertain the depth of the planning on any of these future projects.

These projects which establish community or two year colleges in other nations are operating from the premise of educating both US nationals studying abroad and the nationals of the host country. Again, there is very little available to the researcher in the literature or from the initial questionnaire used in this study about the extent of community colleges operating branch campuses in other countries.

\section{International Education Consortia}

The eighth dimension in the taxonomy is the involvement of community colleges in international education consortia. The literature suggests that US cormunity colleges operating 
as single units often cannot afford to get involved with international projects from either a political or economic reality due to local concerns. Even though the leadership may very much want to be involved, the only alternative to "going it alone" is to belong to an international consortium of two or more community colleges (Adams 1979 and Gleason and Hazelwood 1987).

The consortium is usually based on a common interest in one country or region of the world or a common bond, such as being in the same state or in the same region. King and Fersh (1989) point out that there are "more than a dozen" consortia working to assist individual community colleges organize and develop any and all international programs and activities. Some examples include the American Association of Community and Junior Colleges (AACJC) which began as a consortium for the development of community college interests in international activities in 1976. Today, more than one hundred community colleges belong to the AACJC International Intercultural consortium, of which thirty are foreign operated community colleges, mostly in Canada. A very selective international consortium is the community colleges for International Education, with the main offices at Brevard Community College in Florida, that allows only twentyseven member schools to participate. Another selective world-wide consortium for community colleges is EPIC, Educa- 
tional Partners for International Cooperation, with only twelve members. Several states support consortia on international education. And, there is one Pacific Northwest regional consortium on international education (Kelleher 1985), The Northwest International Education Association. The survey questionnaire sent out to all forty-three public community colleges in Oregon and Washington states included one question asking the respondent to list any international education consortia to which they belong. The responses indicated twenty-two schools belong to one or more consortia (73\%). Sixteen of the nineteen Washington community colleges responding $(84.2 \%)$ and seven of the eleven Oregon community colleges responding $(63.6 \%)$ belong to one or more consortia. The mean number was 1.3 , the median was 1.0 , and the range was 0 to 4 .

The data further revealed that the twenty-two schools which belong to consortia are involved in twelve different consortia. Thirteen schools $(43.3 \%)$ belong to the Northwest International Education Association, while only three schools in the two state region (10\%), one in oregon and two in Washington, belong to the national AACJC International/ Intercultural consortium. It was a surprise to learn that two schools, North Seattle Community college and spokane Falls Community College, belong to the very selective Community Colleges for International Development Consortium 
mentioned above. It is, perhaps, noteworthy to remember that these two schools were the only two community colleges in the region to receive Title VI(b) grants as well. Mt. Hood Community college is the only school in the region to belong to EPIC.

Fifteen schools, or one-half of the respondents, listed the American Institute for Foreign study as a consortium for international education. There appear to be several smaller consortia within the region such as the southwest Washington Consortium for International Education, with three schools, and the Eastern Washington Consortium for International Education, with two schools active during the 1989-90 academic year. And, one school, Spokane Falls, belongs to a city-wide consortium called the spokane consortium for International studies.

\section{Study Abroad Programs for Faculty and Students}

The ninth dimension in the taxonomy on international education programming is that of study abroad programs for faculty and students. According to the very limited literature and research on community college study abroad programs, the two year colleges of the United States have been very slow to recognize the value of faculty and student study abroad programs (Boyer 1978). As a part of the study, faculty experiences in international activities were surveyed (see Figure 16). A number 
of community colleges were found where the faculty have been fairly active in the area of exchanges, living, and travelling abroad.

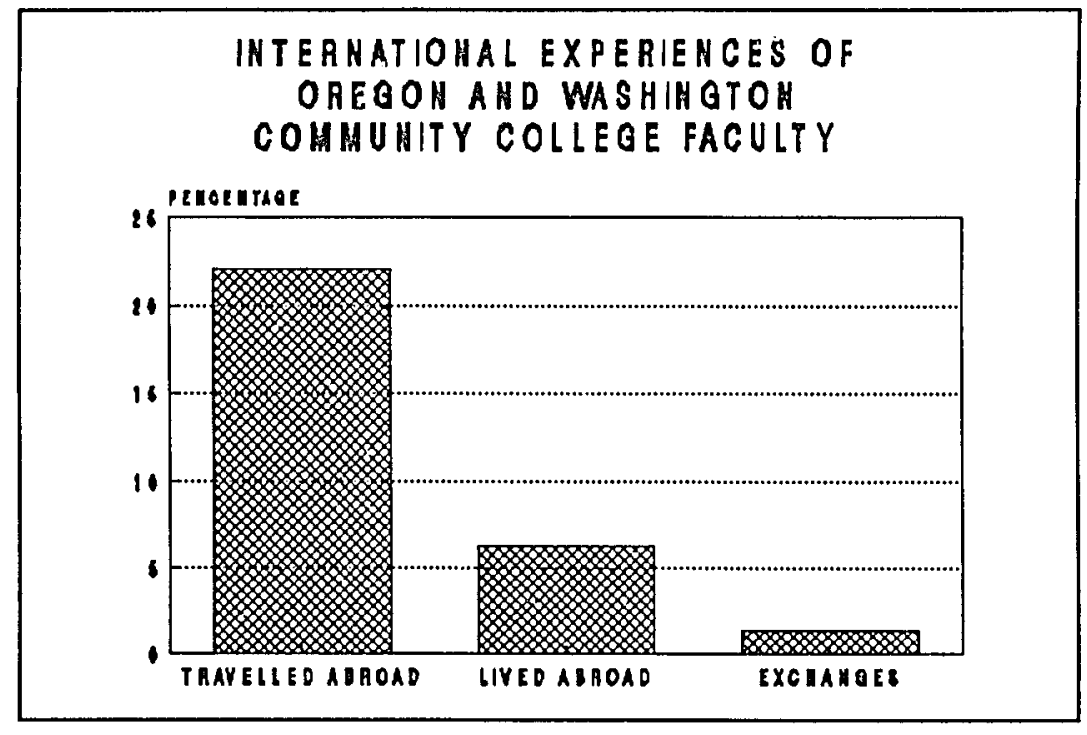

Figure 16. Faculty International Experiences.

on the whole, however, community college faculty involvement in the past ten years has been meager at best. For example, the actual number of faculty who have had exchanges abroad totalled only 54 over the ten year period. That means, there have only been 1.8 exchanges per campus since 1980 . This represents only 1.4 percent of the total faculty in the two state region. From the total faculty of 3,763 in the thirty schools, only 6.3 percent (237) have lived abroad during the past ten years. Twenty-two percent (827), or nearly one-quarter of all the faculty, have, however, travelled abroad during the past ten years. Shoreline community 
College faculty led the way in travel with 100 members finding their way abroad. Lane community college faculty, with 78 individuals, was the second most active, while Mt. Hood faculty were third. The survey instrument did not, unfortunately, lend itself to discerning more information about faculty study abroad opportunities. Other than the American Institute for Foreign Study (AIFS) program, which included a certain number of faculty to both teach and study abroad while participating with their students in the same program, no questions were included to understand the nature of faculty study abroad. The study did, however, determine that 54 faculty have had faculty exchanges, 237 have lived abroad, and more than 820 have travelled abroad in the past ten years. Some of these faculty, no doubt, have used resources other than their own to obtain these opportunities.

Due to the low cost of tuition and the idea that community colleges are primarily for commuter students or students only interested in learning a job skill, local boards of trustees and administrators have been slow to advance the concept that an international experience will make the student a better educated person, regardless of their academic interests (Boyer 1978).

The data from this study revealed that the American Institute for Foreign study, a private not-for-profit 
organization begun in 1964, has been active in assisting a number of Oregon and Washington community colleges in establishing a consortium for the purpose of recruiting faculty and students to teach and study in England each spring quarter. Fifteen community colleges (50\%) participated in this effort in 1989-90.

The data further revealed that an estimated 617 community college students from oregon and Washington studied abroad for one quarter or more during a three year time period, 1987 to 1990 . The mean number of students studying abroad in this three year time frame for all thirty schools was 20.57 , or less than seven per year, while the median was 5.0 and the range was from 0 to 170. Shoreline community College in Washington state led all schools with 170 students abroad, while Rogue community college in Oregon had 100 of its students studying overseas in the same three year period.

In 1989-90, oregon and Washington community college students studied in nineteen different countries. The most popular place to study, by far, was in England. This came as no surprise, since English is the native language of the hosts and AIFS had been working with fifteen regional colleges on a London, England project. Thirteen schools, most of which worked with AIFS, sent their students to England. 


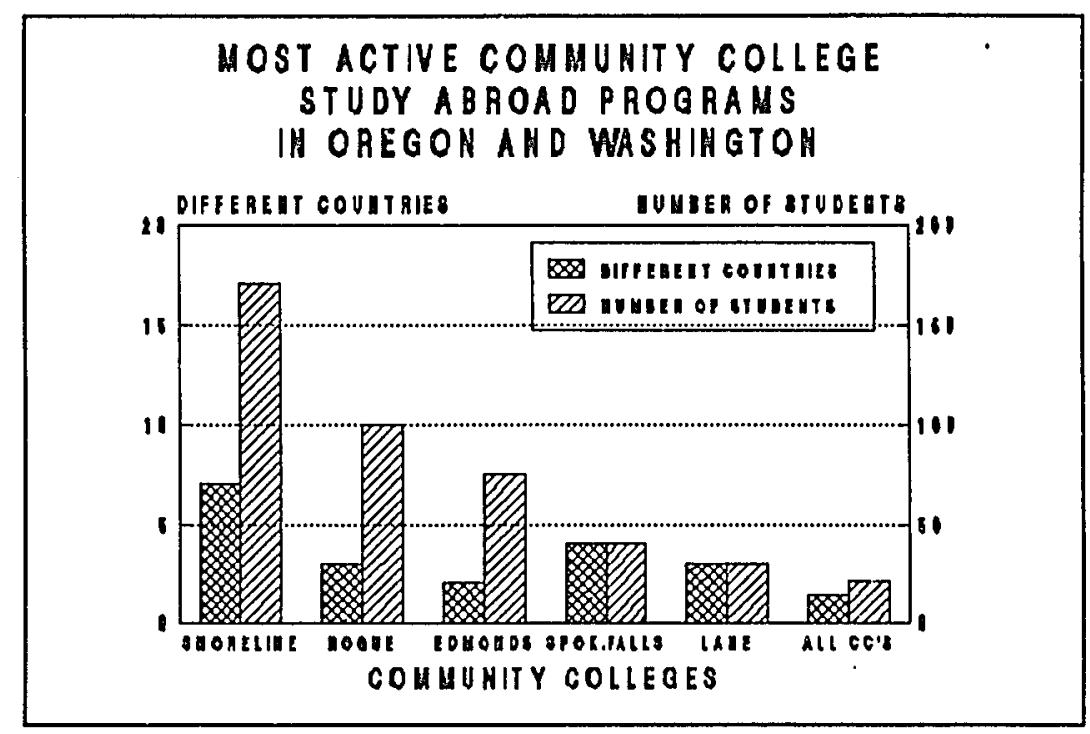

Figure 17. Study Abroad Programs.

The second most popular place was Germany, with five schools sending their students to study there. Mexico and France received students from three of the region's community colleges. Japan, which wasn't too surprising, hosted only two schools. Oriental languages, while catching on quite rapidly in the community colleges of oregon and Washington, are still considered the most difficult to master. There were oregon and Washington community college students in the following countries during 1989-90: Chile; Ecuador; Belize; Ireland; Hong Kong; The Netherlands; Argentina; Kenya; Turkey; Tunisia; Spain; and the Soviet Union. When a community college utilized a consortium for student study abroad programs it most likely was AIFS, although the Consortium for International Education studies 
(CIES) and the spokane Consortium for International Education were used by two schools in the region to assist them in sending students abroad. A few responses indicated that their own faculty on foreign study projects led their students in study abroad programs.

Still, the number of students and the number of different countries visited by the students studying abroad came as a mild surprise given the pessimism found in the literature. As travel becomes more readily available, more community college faculty and students will, undoubtedly, find their way abroad in the future.

\section{Overseas Military Programs}

The tenth, and final, dimension in the taxonomy on international education deals with overseas military programs. The data revealed that only one community college, Big Bend, has an overseas military program. Big Bend Community college has been involved with military contracts since 1970. This small rural eastern Washington community college served more than one thousand college students during the 1989-90 school year in Germany, Italy, England, and Saudi Arabia, employing 850 staff members, including full- and part-time faculty. The European-based contract employs a Vice President for Operations, who reports directly to the President of Big Bend, a Dean of Instruction, and several other full-time administrators, in addition to faculty and 
classified staff. Curriculum matters are coordinated between the home campus Dean of Instruction and the Europeanbased "headquarters" in Germany.

Big Bend Community College started its involvement with the US Army twenty years ago by offering high school completion course work for GI's. After eight years, the washington college started offering a college transfer curriculum for army personnel and their dependents in Ger-many. Today, a complete transfer program and several vocational/technical programs are offered in four foreign countries under several military contracts.

Faculty, staff, and students studying at an overseas off-campus location, whether sponsored directly or indirectly by the military for military personnel and/or their dependents, under the auspices of an accredited community college, are enjoying all the benefits of an international experience very much like a study abroad program. The fact that the branch campus is being funded by a military contract has no bearing on the experience, particularly if the faculty require off-base or off-campus activities to supplement instruction.

The real surprise in the data was that there aren't more schools involved in providing college courses and programs to the armed services overseas. 
THE MOST ACTIVE COMMUNITY COLLEGES

The second purpose of the survey questionnaire was to quantify and manipulate the data in such a way as to clearly and equitably identify three of the most highly developed community colleges in the field of international education from the two states. After examining the issue of the weighting and achieving equitable balance for all factors identified from the survey instrument, it was possible to determine the level of involvement of all thirty community colleges taking part in this study (see Appendix D). The following chart ranks the six most developed and active community colleges in the Oregon and Washington region in the field of international education by the number of points received.

THE HOST ACTIVE COHHUNITY COLLEGES

IN THE FIELD OF IHTERNATIOHAL EDUCATION

IH OREGON AND WASHINGTON STATES

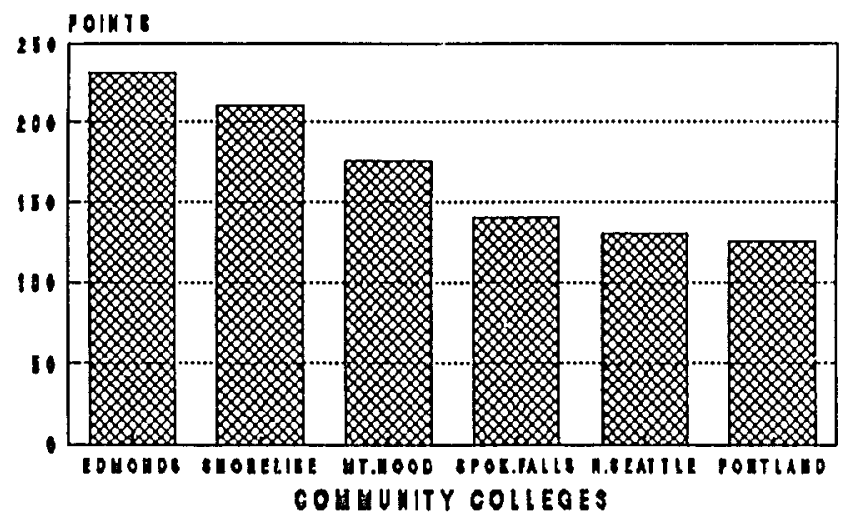

Figure 18. Most Active Community Colleges. 
From the six community colleges, three clearly emerged as the most developed and the most active across the taxonomy in the field of international education within the two state region: Edmonds Community College in Washington state; Shoreline Community college in Washington state; and, Mt. Hood Community college in oregon.

Many schools were quite strong in certain areas but not strong enough in all areas to gain enough points in any of the data runs to be considered the most developed and comprehensive in the field of international education. For example, Tacoma, Yakima, Clark, South Puget Sound, and Spokane all devoted staff resources to international education exceeding or comparable to Edmonds, Shoreline, and Mt. Hood but did not show evidence of much participation in other areas. On the other hand, as Figure 19 below shows, the three most comprehensive, and thus the most developed community colleges in the field of international education, while showing up often in all areas of the rank-order categories, were ranked number one, two, or three thirteen times out of the forty-one weighted responses. They were, however, involved in practically all facets of international education. Chapter $\mathrm{V}$ details what each of these three schools are accomplishing in the field of international education to earn the distinction of being the most developed in the two state region of oregon and Washington. 


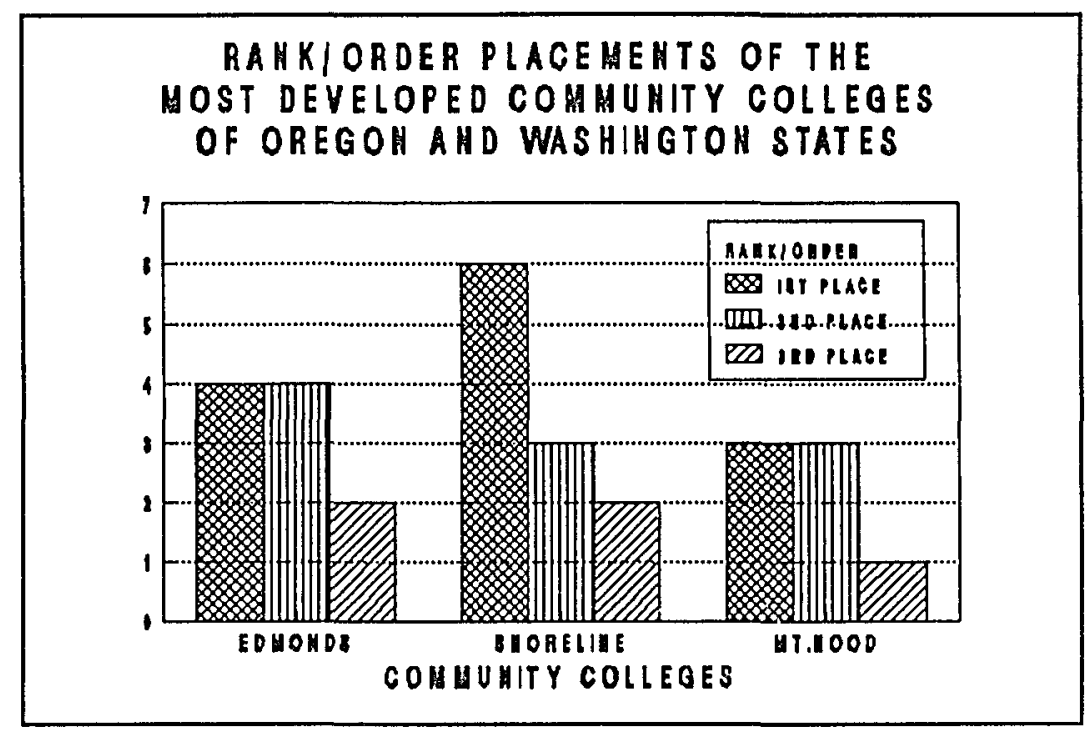

Figure 19. Rank and Order.

\section{SUMMARY}

There were two primary purposes to be served from the survey questionnaire. The first purpose was to identify and describe the current status of international programs and activities in the community colleges of oregon and Washington states as they existed during the 1989-90 academic year. The second purpose of the survey questionnaire was to quantify, analyze, and interpret the data in such a way as to clearly and equitably identify the three most developed community colleges in the field of international education from the two states.

The data demonstrated that many Oregon and Washington community colleges are, indeed, involved in the dynamics of 
international education to an extent not previously understood. The data also demonstrated that, while there are many international education programs worthy of being deemed highly developed, three community colleges, Edmonds, Shoreline, and Mt. Hood, received the greatest number of points from the survey questionnaire and were selected for further in-depth case studies. 


\section{CHAPTER V}

\section{CASE STUDY RESULTS}

In this chapter, the results of three case studies of the most highly developed community colleges in the field of international education from the states of oregon and Washington are presented. Edmonds Community College (WA), Shoreline Community College (WA), and Mt. Hood Community College (OR) were selected for case study analyses on the basis of their overall international activities and programs identified from the initial survey questionnaire distributed to all forty-three public community colleges in oregon and Washington states. The three schools received the highest total points determined by a weighted numeric system applied to the initial survey questionnaire results from the thirtythree responding institutions (see chapters III and IV).

\section{PURPOSES OF THE CASE STUDIES}

In his book, Approaches to International Education, Earl Backman (1984) pioneered in the use of case studies to understand and appreciate what two-year colleges and fouryear colleges and universities were doing in the field of international education. While he himself did not conduct 
the eighteen case studies for his book, per se, he provided the structure for other writers to describe in-depth what was happening at their institutions in this particular field. He suggested there were several purposes to be served from the international education case study analysis. One purpose was to identify and describe the current status of international programs and activities as they existed at a certain time. A second purpose of the case study analysis was to provide additional perspectives to the research based literature. A third purpose, he believed, was to provide results that could be used by college and university practitioners and others, if they so choose, to gain insights into the many facets of international education.

Earl Backman (1984) used a series of general topics as a guide for other writers to describe international education on their home campuses for his book, Approaches to International Education. The author of this dissertation utilized the same guide to construct an interview protocol, which was used in the presentation of the following three case studies.

EDMONDS COMMUNITY COLLEGE

\section{Introduction}

The following case study of Edmonds community college in the state of Washington was compiled through the use of 
interviews with key personnel during a two-day visit to the campus in April, 1991, and the use of relevant documentation. Interviews were conducted with the president, the associate dean for international student programs, the division chair for international education, the dean of student services, two part-time ESI instructors, several international students, and several classified staff members, both in and out of the international education arena. Documentation included the college catalog, international studies curricula information, college organization charts, international student brochures, recent copies of the international newsletters from campus and the Japan center, and college statistics. Several post-interview telephone calls were made for follow-up details in May and June. (The author of this dissertation personally knows several of the international education personnel for the past several years as a result of professional contacts.)

\section{Institutional Description}

Edmonds Community College is located just north of the Seattle city limits and just across the king county line. The college is one of five community colleges found along the I-5 corridor from downtown seattle going north to Everett, each one only about five to seven miles from each other. The main campus is one block west of Aurora Boulevard, a six lane main north-south arterial leading out of 
Seattle, which contains the highest concentration of strip malls and shopping for the northern suburbs.

Everett Community college was established in the early $1930^{\prime} \mathrm{s}$. In the 1950's, Everett opened a second campus in the southern most part of Snohomish County near Edmonds and Lynnwood, Washington. The campus became known as Edmonds Community college. A new building site was secured in the city limits of Lynnwood in the mid-1960's, although the name Edmonds continued. A small, compact campus with four major structures capable of serving between 3,000 and 4,000 fulltime students was constructed in the early 1970's.

After a number of disagreements between the campuses, a division of the district took place in 1979 leaving Edmonds as a stand alone community college district. Today, the Edmonds Community College District serves the smallest geographical area of the twenty-seven Washington state community college districts and serves about the median number of students. About four to five miles wide by six to seven miles long in size, three population centers, Lynnwood, Edmonds, and Mountlake townships, are inside the district boundaries.

\section{$\underline{\text { students }}$}

During the 1989-90 academic year, Edmonds Community College enrolled 4,500 full-time equivalent students. More than 11,000 individuals, by headcount, attended Edmonds. 
Women made up the majority of students, with the average age about thirty-one, a slight decline from previous years when it had reached slightly over thirty-three. Most students work while attending school. The student body is not typical of the average northwest community college when considering racial, ethnic, and cultural diversity, due to the large number of Asian Americans living in the district and the large number of international students.

In 1989, Eamonds Community College enrolled the highest number of international students of any community college participating in this study with 450 . This represented 10 percent of the total enrollment. In 1990, the college increased its international student body to 620 , increasing the percentage to 13.8 . Forty countries are represented in the international student body. Most of the international student body comes from Asia, with Japan, Korea, and China well represented in the group. In 1988, the president of the college, Mr. Tom Nielson, thought the international student body needed more representation from European cultures. The college used a strategy of employing an agent or representative in France to help recruit French students for the main campus. After the agent had set up a number of high school visitations and college fairs, the president sent a team of Edmonds Community college staff to make personal face to face contacts with potential students. The 
agent, who received ten percent of the tuition for each of the first three quarters of enrollment, then does the follow-up and paper work for the students while they are still in their home country. As a result of this strategy, Edmonds Community College increased its European and French student body by seventy-five students. College staff became familiar with the arriving students and the staff had the opportunity to travel abroad.

As a result of heavy marketing and recruiting of international students, there is definitely an atmosphere of being a part of the world community when visiting the Edmonds Community College campus. International students can be spotted in practically every corner of the medium size campus. There are two small, converted two story houses near the front entrance to the college dedicated exclusively to international students services, as well as containing an international travel agency.

Edmonds Community college participates in a number of organized international projects that also help bring international students to the campus, including a federally funded project through Georgetown University and the US Agency for International Development, called CASS. The 17 CASS students were studying computer repair and electronics and came from Central America and the Caribbean Basin. The 
students' native languages included English, French, and Spanish.

In the 1989-90 academic year, Edmonds Community College opened a branch campus in Kobe, Japan, enrolling a charter student body of 460 students. In 1991, when the Japanese academic year began, the Kobe campus started the second year of operations in Japan with 660 students, an increase of almost thirty percent. These students are not counted toward the campus numbers and are not counted in the international student totals submitted to the state of Washington. If they were counted along with the main campus international students, Edmonds Community College would have 1,280 international students for the 1990-1991 school year. However, due to heavy marketing of Edmonds Community college in Japan, both on the Kobe campus and around the island nation, administrators anticipate even larger numbers of Japanese students to take classes on the main campus in the next several years.

\section{Faculty}

In the 1989-90 academic year, Edmonds Community college had a faculty of 88 full-time instructors on the main campus with another 20 full-time instructors assigned to corrections Education. In addition, there were 54 full-time instructors working at the Edmonds Japan Campus in Kobe, where there is a 22-1 student-faculty ratio, which is 
slightly lower than the main campus. Most of the Japan Center faculty teach ESL. Out of the 162 full-time faculty, 18 (11\%) hold the doctorate; most hold the master's degree, with about ten percent of the total faculty possessing less than the master's. Of the total staff, fifty-eight percent are male.

The number of foreign born faculty equal only five. It was surprising to note that Edmonds Community college, with the largest number of international students, had so few foreign born faculty and staff. In fact, this study showed that the average community college had 5.7 foreign born faculty members, leaving Edmonds Community College somewhat below the average.

\section{The Community}

While many, if not most, community colleges restrict their enrollment and thinking to a very localized geographic area, the "community" that Edmonds Community college serves is the world. The dean of students, paraphrasing the president of the college, insisted that Edmonds Community college was not a "state funded" community college but a "state assisted" community college; therefore, the student body can come, literally, from anywhere in the world.

Does that mean Edmonds Community College ignores the needs of the local residents of their District? According to the dean of students and others interviewed, local resi- 
dents are truly enriched by the presence of so many international students and visitors from around the world. Those interviewed seemed to suggest that there was an organizational culture that advocated that what is good for the world is good for Edmonds Community college. Thus, if the college can bring a part of the world to Lynnwood, the local residents and students are the ultimate beneficiaries of this policy. And, while there are from time to time vocal critics, close to home and around the state, of such a policy, the college staff that were interviewed felt that this philosophy and way of thinking was well integrated into the overall educational mission of the college. Those interviewed also felt that the criticism of not being in touch with the educational needs of the local residents can also be deflected on another level, too. They pointed out that there are four other community colleges all within fifteen or twenty minutes of the Edmonds campus. Because there are no out of district restrictions in the Washington state community college system, local residents may perceive that they have many choices of colleges and that Edmonds has merely carved out a very special niche for the special student who wants to be involved in an international setting without leaving home. 


\section{College structure and organization}

Edmonds Community College has one main campus, two corrections centers within the district, and one campus in Kobe, Japan. The district is headed by a five member Board of Trustees selected by the governor of Washington State. Board members serve for four year terms. The Board of Trustees, through a state board and working with local officials, sets policies and leaves to a twenty-six member Administration the rules and regulations by which the college is organized and operated.

The president, Mr. Thomas Nielson, has been in office since 1980. There are three vice presidents that report to the president: An executive vice president, responsible for instruction and student services; a vice president for finances and operations; and, a vice president for the Japan campus. The director of human resources also reports to the president.

There are three full deans at Edmonds Community college: A dean of instruction; a dean of students; and, a dean of instruction, Japan. The former two report to the executive vice president, while the latter reports to the vice president for the Japan campus. There are four associate deans: college relations and development; international student services; student information systems and services; and, applied technology. They report to the executive vice 
president. There are a total of sixteen directors. Eight directors are responsible for instructional divisions on the main campus, including one international education director; a director for each of the two corrections programs; two directors report to the vice president for finances and operations: and four directors report to the dean of student services. In addition, there are two assistant directors, one coordinator, and one manager listed in the catalog as administration or professional support staff.

\section{History of the International Education Programs}

According to Mr. Tom Nielson, international education programs and activities did not start out from the perspective of a well-thought out philosophy, but rather from the very pragmatic need for the college to survive economically. In the 1980-1981 academic year, the then governor of Washington state, John Spellman, ordered all state agencies to reduce their budgets by ten percent or more. Mr. Nielson, just having started in his first presidency, realized that there are only two ways to balance a budget: cut spending or increase revenues.

Dr. Roy Ghazimorad, now the associate dean for international student services, remembers that he and a former colleague, Linda Quan, suggested to the president that they try an experiment to bring more revenue to the college: The college should place all international student services, 
including classes and course work, on a "cost plus" basis for the summer program. The experiment worked, the college made a little money and covered all direct costs associated with the summer program. Dr. Ghazimorad felt that an entrepreneurial spirit was given life -- a spirit that he and others feel permeates the entire organizational culture of Edmonds Community College today.

In time, all international student services were placed in the category of contract services. Dr. Ghazimorad, and many others, became more active in securing grants and contracts in the international education arena. Through the leadership of Tom Nielson, a contract was secured with the Indonesian government that provided technical English training and technology transfer. Similar contracts were entered into with foreign governments working with the Boeing Company, which is located nearby the main campus. Each of these contracts made money for the college and covered all direct costs. At the same time, more and more international students were being recruited world-wide.

The search for new grants, contracts and international students created a competitive edge to the college's marketing. Edmonds Community college, according to many of those interviewed, seems to go out of its way to be competitive with both other community colleges and its much larger neighbor, the University of Washington. More than one 
interviewee delighted in telling how Edmonds has beat the UW to the scene of several international ideas, especially in the creation of the Japan campus.

with each new contract and with each new international student, the campus became more and more intertwined with an emerging philosophy about international education. During this same time period, the first five or six years of the $1980^{\prime}$ s, the concept of the Pacific Rim was coming into full blossom. More and more Japanese leaders in politics and business were coming to the seattle area to investigate new opportunities for business, education, and training. Many of the Japanese leaders, some of whom were educated in the United states themselves, were looking for innovative ways to educate the next generation of Japanese.

President Nielson, seizing the momentum of Seattle becoming a gateway to the Pacific Rim, travelled abroad extensively telling the Edmonds Community College story to foreign dignitaries and international business leaders alike. Through the leadership of the president of Edmonds Community college, the concept of establishing community college branch campuses in cooperation with Japanese business leaders was born. starting in 1987, Mr. Nielson and the Board of Trustees at Edmonds began cultivating a pioneering effort between Japanese business leaders and American community colleges. 
On one of his later trips to Japan, Mr. Nielson made a connection with several business and civic leaders from the city of Kurashiki. This city is located far from the hustle and bustle cf Tokyo and osaka; yet, they wanted an American college for their community. (The Japanese "junior" college is not very similar to the American community or junior college. In Japan, the junior college has traditionally been for women and is considered to be a finishing school for the domestic arts.)

In 1988, Mr. Nielson visited Kurashiki and actually signed a letter of intention to enter into a future agreement with the Kurashiki leaders to provide an American educational experience for Japanese students in Japan. Leaders from the city of Kobe, a much larger city to the north and closer to osaka right on the bullet train route, hearing of the deal being made in Kurashiki, sought out Mr. Nielson and wanted a similar American school for their city, too. A third group of civic and business leaders from Kanuma, likewise, sought out Mr. Nielson and offered him yet another opportunity.

Edmonds Community College, for all their international education experience, thought the better of trying to establish three campuses at once and vowed to their new Japanese partners that they would work very hard to bring two other American community colleges to set up the three campuses. 
For Edmonds, they chose the Kobe opportunity. Kurashiki leaders got together with Mt. Hood Community college in oregon after an unsuccessful series of negotiations with Clark College in Vancouver, Washington. And, Kanuma leaders got together with Green River community college. (The latter effort having been mutually terminated after just one year of operations -- see Japan Times, October 5, 1991.)

In 1989, President Nielson adoled to the main campus a new academic division for international education. It contained several major thrusts: An international studies major; an international business major; English as a second language for recent emigres; study abroad programs; and, the education of American students at the Kobe campus. Iike the international student services operation, this academic division of the college was created as another "entrepreneurial zone" and must be cost covering while attempting to make money for the college's general fund.

So, what started out to be a mission to save the college from dire economic straits, evolved into a new, innovative enterprise with a mission of its own: the internationalization of Edmonds Community College. As Mr. Nielson said, "if I knew then what I know now about the spirit of internationalism, I would do it lall over again even if we didn't make money at it." 
Funding and staffing for International Education

The funding for international education is, as we have seen above, primarily from grants, contracts, and student tuition and fees. International education and programs can be found in three basic areas of Edmonds Community College: In the international student services division; in the international education division; and, in the president's office. International education and programming, however, can be found throughout the campus as a result of the college's overall efforts in this field. Even the Edmonds Community college Foundation is involved in some fund raising activities for international education programming.

International student tuition in 1990-91 was set at $\$ 1,134.00$ per term for a full-time student taking 10 to 18 credit hours. With 620 international students, the college will receive more than $\$ 703,800.00$ each quarter or more than $\$ 2.1$ million for the academic year, not including additional fees for summer, labs, books, et cetera. The college, in turn, provided enough full-time ESL instructors in the international education division and additional ESL instructors in the international student services division, depending on the needs and the skills level of the international student. The total number of fte ESL instruction was approximately 13. The ISS Division provided a total of fourteen instructors, advisors and staff to assist international 
students on campus. The two international administrators and secretarial staffs were also available for international education programming.

All international study abroad programming was paid for by student fees. Through a variety of arrangements, depending on the private agencies involved, the destination, the number of faculty participating, et cetera, a study abroad program can be cost covering with as few as eight student participants. Edmonds Community college has averaged just seven students a year in its two study abroad programs from 1987 to 1990.

In April of 1990 and with the opening of the Kobe campus, Edmonds sent fifty American students to the new campus in Japan to study abroad. The American students came from all over the state of Washington. For a $\$ 2,300$ fee, the American student is enrolled full-time, provided air transportation to and from Japan, and provided housing. Food, health insurance, books, and personal costs are at the student's expense. As an incentive to study in Japan, Edmonds Community College will reduce the student's $\$ 2,300$ fee to just $\$ 1,700$ if the student will act as an English language tutor for ten hours each week during their stay. To effect a meaningful, and low cost, international study abroad and exchange program, Mr. Nielson and others in the community college system went to the legislature in 1987 
and secured a law allowing for a new community college international student exchange program. With the new law, a community college can waive non-resident fees for up to one hundred international students. The Kobe partnership can exchange an equal number of American and Japanese students studying at either campus for the resident fee charged on the main Edmonds Community College campus. Thus, Edmonds Community college students are advantaged in the exchange. The Japan campus administration reports to the president's office, although many of the operational aspects of the enterprise are dispersed throughout the organization. As a result, the Kobe contract arrangements continue to be negotiated with the president directly. Each training contract, such as the Kobe campus, is a unique financial arrangement that provides the college cost covering and an administrative overhead for indirect costs. The Kobe campus, in addition to paying for all costs of the program, provides the college with a "royalty" on total income to the school. Edmonds Community College officials did not reveal the exact percentage of income from the Kobe campus. However, it is probably in the three to seven percent range, which should have provided approximately $\$ 100,000.00$ to $\$ 230,000.00$ for the first year's operation with 450 students in attendance. With 660 students in school the second year of operation, Edmonds Community College will earn up to 
$\$ 340,000.00$ or more depending on the uniqueness of their contract with their partners.

The case for economic considerations and an entrepreneurial spirit in the field of international education is secure at Edmonds Community College.

\section{Goals and Objectives for International Education}

From the initial survey questionnaire, from interviews and from limited available documentation, it was very clear that Edmonds Community College staff, and especially the president, have set even higher goals and objectives for the continuation and development of international education on their campus.

In the initial survey instrument, Edmonds staff indicated that international education was a middle to high priority of the campus. The initial survey questionnaire also revealed that they expected to be more involved in international education in the future. From interviews, the staff, in general, wanted to strengthen existing efforts and make those changes that would result in new programs. All indications are that international education will grow even stronger than what it is currently.

Surprisingly, there was little or no documentation for any long range planning or specific initiatives in international education for the future of the college. Edmonds Community College does not invest a lot of time nor effort 
in either long range planning or strategic planning; yet, there was a clear consensus about specific future programs among the staff interviewed. Communications about the future appear primarily in private correspondence in the form of memos or face to face meetings.

One specific goal of the college is to work more closely with Europeans, Eastern Europeans, and Russians to bring students from these countries to the main campus. A second goal is to affect more meaningful. opportunities for American students to study abroad, especially with an eye to spain and France. Thus, the three foreign languages currently being taught on campus, Spanish, French, and Japanese, will all be rooted in real living experiences from branch campuses or extension centers of Edmonds Community college. A third goal is to reestablish ties with Iran, which were suspended after the 1979 revolution in that country. Prior to the revolution, there were many Iranian students studying in the seattle area, including several at Edmonds community College, under the tutelage of Dr. Ghazimorad, who is an Iranian himself.

It is with a global geo-political view of the future that international education initiatives are being planned for this campus. The president believes that the major shifts in current events -- with Europe centralizing, the Soviet Union dismantled, the Eastern European nations shift- 
ing to capitalistic democracies, and the Iranians coming back into favor with the rest of the world as the Iraqis fall from power -- will all have an impact on Edmonds Community college and its place in the world.

Strengths and Weaknesses of International Education

One of Edmonds Community College's greatest strengths is its large and highly diversified international student body. With 620 international students on campus, no other community college comes close to possessing the incredible wealth of human resources of Edmonds Community college. The college has employed the necessary staffing to meet the needs of such a large and diversified international student body.

Another strength of the college is the strong leadership of the president in his promotion and commitment to international education. From every public document to every facet of the college, international education can be viewed. The innovations and risk-taking involved in creating a business partnership for a Japan campus are impressive even to the critics of international education.

The entrepreneurial spirit that permeaces the campus is also a strength in that it constantly challenges faculty and staff to find new ways to accomplish traditional tasks, whether they be lecture materials or saving the college by bringing in new sources of revenues. 
While it is definitely a strength currently, the large number of international students on campus could become a liability or weakness should current conditions change. For instance, if a major war between the United states and another nation with a large student population at Edmonds were to break out, the college would find itself in the middle of an international crisis on campus and in the community that most other community colleges wouldn't have to face. That is an extreme situation. The more likely scenario would be to have a reaction in the immediate community of Lynnwood to one or more "international" student issues. Resident citizens could confront the Board of Trustees and the administration over these issues and attempt to force unacceptable or negative responses to college policies and practices. This has not been an issue thus far in the history of the college's involvement in the international arena, however.

Some potential weaknesses exist in the ESL delivery system. ESL instruction can be found in the two divisions most responsible for international education. There is a tendency, according to Dr. Ghazimorad, for the ESL instructors from the two divisions not to spend time together communicating mutual concerns and issues. As a result, the ESL instructional staff will, sometimes, receive contradictory pedagogical directions. 
A real potential weakness of the international education programs and activities is with the president himself. So strong is the president's stamp of approval and involvement that if Mr. Nielson should ever leave the college, the international education programs and activities might not have the same high priority as they currently enjoy and lose some of its initiative. However, all of those interviewed suggested, when the topic was brought up, that the college would, indeed, carry on a strong and robust international education program should Mr. Nielson ever leave his post, because it was fairly well entrenched and a permanent part of the college. They all agreed, too, that international education would lose its prime mover and new initiatives would probably slow down or stop, so profound is $\mathrm{Mr}$. Nielson's imprint on this particular college activity.

\section{The Future of International Education}

There was strong agreement that the pursuit of international education programs and activities had served the college and the community extremely well during the past ten or eleven years. Mr. Nielson was given full credit for his vision, his risk taking, and the development of the total college with international education in the foreground of much of what they do. 
SHORELINE COMMUNITY COLLEGE

\section{Introduction}

The following case study of shoreline Community college in Washington state was compiled through the use of interviews with key personnel during a one day visit to the campus in April, 1991, and the use of relevant documentation. Interviews were conducted with the president, the division chair for the social sciences, the coordinator for international student services, several international students, and several classified staff members, both in and out of the international education arena. Documentation included the college catalog, international studies curricula information, college organization charts, international student brochures, recent copies of the international newsletters, and college statistics. Several post-interview telephone calls were made for follow-up details in May and June.

\section{Institutional Description}

Shoreline Community College, which was begun in 1965 as a joint project of two $\mathrm{k}-12$ public school districts, is located in the northern most part of the city of seattle five and half miles from downtown in a fairly prestigious residential district just a half mile from prime Puget sound beach areas and a half mile west of busy Interstate 5 . The 
King county line is less than a mile to the north of the main campus and serves as one of the district boundaries. In 1967, the Washington legislature created a statewide community college system with Shoreline community College forming District Seven, which serves the original two K-12 public school districts as its entire district: Shoreline Schools on the west side and Northshore on the east side. The district is small in size, running mostly east and west from the Puget sound to the northeastern tip of Lake Washington and the city of Bothell, but heavily populated in residential areas.

The University of Washington, with its 35,000 students and its preeminence in pacific northwest postsecondary education, is about four miles away. The influence of the University of Washington can not be understated in an examination of the seattle area community colleges.

The Shoreline Community college campus lies very near the western most part of the district due to a major land gift by a member of the Boeing family in the mid-1960's. students coming from the eastern most part of the district must travel more than thirty minutes by car if they choose Shoreline at all. (Under Washington state rules, a student can attend any community college of his or her choice in the state without paying additional out of district fees. Be- 
cause the community colleges of Washington state all belong to one state system, it is not uncommon for community college leaders to speak in terms of serving the needs of Washington state rather the needs of a close-by community. In fact, very few references were made to local community needs in any of the interviews conducted at shoreline or Edmonds community colleges.)

The main campus is made up of twenty buildings all with the same architecture than can be characterized as Japanese Pagoda style. Most are one or two levels and serve a specific academic or service function. They are fairly close together in a well landscaped and well maintained setting. The consensus seems to be, however, the college has reached its physical capacity for morning and evening classes.

Shoreline Community College recently opened a very small four classroom facility located north of Bothell to serve the needs of its eastern constituents. Howard Vogel, social sciences and international studies division chair, pointed out that in the state of washington 22 residents out of every 1,000 citizens attended community colleges in 1988 . In the eastern area of District Seven, only 11 residents out of every 1,000 citizens were attending a community college in the same year. The Northshore portion of the district has, in recent years, moved from an agriculture economic 
base to an electronics economic base. The shift has brought in more people and more affluence to an underserved area.

\section{Students}

Shoreline Community college has similar characteristics and statistics to most other community colleges in the Northwest. During the 1989-90 academic year, Shoreline Community college enrolled 4,397 annualized full-time equivalent students. More than 24,000 individuals participated in their education. The ratio of individuals to FTE's was about 5 to 1 in 1989. Sixty percent of the students were women. The average age was about twenty-seven. Typically, most students were working while attending school. The student body is fairly homogeneous with less than 15 percent non-white, including those with Spanish surnames, which is slightly higher than the community the college serves. Asian/Pacific Americans made up fully eleven percent of the student body and eighty percent of the minority population. Shoreline Community College enrolled the second highest number of international students of any community college participating in this study with 290 . This represented about seven percent of the total enrollment. Thirty countries were represented in the international student body, with the highest number coming from Japan: 141.

Shoreline community college participates in a number of organized international projects, most notably study abroad 
programs and the Model Arab League. The college receives no grants for its international programs, although all international students are treated as contract students rather than as a regularly enrolled student. This arrangement has been made necessary due to the student enrollment cap at all community colleges in Washington state imposed by the state legislature after the 1987 school year.

\section{Faculty}

In the 1989-90 academic year, Shoreline community College had a faculty of 143 full-time instructors. From the 143 full-time faculty, 23 (16\%) hold the doctorate. Eleven of the 23 doctorate holders are women. Most of the faculty hold the master's degree, with very few of the faculty possessing less than the master's. Of the total staff, fifty-two percent are male and forty-eight percent are female. Teaching loads are established at 15 credit hours per quarter and are set by contract.

one of the interesting findings from shoreline was its high percentage of foreign born faculty (20.9\%). Thirty members of the faculty were born in places other than the United states. No data were collected on country of origin, however. The presence of such a high percentage of instructors from other countries, according to Howard Vogel, made study abroad programming very easy to implement over the years. In addition, he thought the study abroad programs 
carried over into the classrooms as students and teachers returned to campus with new experiences learned abroad.

\section{The Community}

Because Shoreline Community college is located in the city limits of seattle, albeit on the extreme northern edge, it was difficult to get a handle on "the community" the college serves. It serves a well-established suburban residential area of north seattle and king county but, unlike many American community colleges, there is no one city or community that calls shoreline its community college. The college serves two $\mathrm{K}-12$ school districts and several neighborhoods close by the campus. The three other charted cities in the district, Lake Forest Park, Kenmore, and Bothell, are more like neighborhoods than complete cities.

The residents of snohomish county, the adjacent county to the north, and where Edmonds Community college is located just five miles away, are just as likely to attend shoreline as they are any of the other four community colleges within a fifteen mile radius; thus, obliterating any real sense of community to serve. As the interviewees said, shoreline has to be seen as part of a state community college system serving the people of Washington state as a whole. In the 1989 school year, Shoreline enrolled 912 entering freshman from Washington state high schools. Only $33 \%$ came from the 
two district high schools, while $17 \%$ came from Edmonds High School. Students from north seattle high schools represented another 12\%, leaving $38 \%$ of all entering freshman, not counting international students, from schools some distance from the campus.

\section{College structure and organization}

Community College District Number seven is headed by a five member Board of Trustees selected by the governor of Washington state. Board members serve for four year terms. And, as we saw at Edmonds Community College, the Board, through a state board and working with local officials, sets policies and leaves to a twenty-four member administration the rules and regulations by which the college is organized and operated.

The president, Dr. Ron Bell, has been in office since 1981. Prior to becoming president, Dr. Bell was deputy executive director for the washington state community colleges. And, prior to that, he was assistant to the president at shoreline Community College. Thus, Dr. Bell has been in the Washington state community college system and at Shoreline for most of his educational career.

From the catalog descriptions and interviews, there are three vice presidents reporting to Dr. Bell: academic affairs; student services; and, business operations. A director of personnel, an administrative assistant for college 
relations, and a director of administrative computing report to the president. A new position for the director of the northshore center was created in 1989 and also reports to the president.

Reporting to the vice president for academic affairs are seven division chairs, who are full-time administrators with one or two classes to teach each year, a director of nursing, and a director of continuing education. The director for vocational education shares an office with the vice president for academic affairs.

The vice president for student development supervises four directors, including counseling, student activities, financial aid, and the registrar/enrollment services. The foreign student programs coordinator, who is a member of the faculty, reports to the director of counseling. All business operations are supervised by the third vice president. At the time of the visitation, there were no administrators on campus whose functions were primarily in the area of international education.

\section{History of the International Education Programs}

When the college opened its doors for students in 1965, the campus patterned itself after that of the University of Washington. The college was primarily transfer oriented with more liberal arts students than any other major. That changed in the 1970's when the college embraced a comprehen- 
sive community college model. From the beginning, however, a significant number of international students and international faculty were found at shoreline community college. The University of Washington was, perhaps as important as any single factor, responsible for setting the tone and culture of the new campus which included a world view.

According to those interviewed, international education programs at shoreline Community college owe their beginnings to the efforts of a now retired instructor and counselor, Mary stephens. Ms. Stephens urged the college to recruit as many international students as possible. Her philosophy was that through international students the college would become diversified and that international programs would be developed as a direct consequence of their presence.

A strong international student body has been the hallmark of Shoreline Community College's effort in this arena. Ms. Stephens became the college's first coordinator for international students. She, and several others, were the chief sponsors for developing study abroad programs and internationalizing the curriculum in addition to caring for the international students.

One of the more striking features of the recruitment and retention of international students is that an international student applying to shoreline community college need not take either the TOEFL exam or the Michigan exam for 
English language proficiency. The international student, however, must be a high school graduate and show an ability to pay for his or her education. The student may take one or more of the English proficiency tests if they wish and submit the results with their application if they so choose. The student is tested for English language proficiency and ESL placement after they arrive on campus and placed in the appropriate curriculum. The net effect of this policy is that Shoreline receives many more applications than they can possibly admit and the average stay for an international student is three years.

According to the president, Dr. Bell, international education has always been a part of the shoreline community College mission but one not necessarily promoted extensive1y. It exists because of faculty and staff interest. The Board of Trustees, with Dr. Bell confirming, has never really "pushed" international education as a high priority, although it has supported a number of highly visible projects through the years, most notably the recruitment and retention of international students.

In the past four years, several significant changes have occurred at Shoreline Community college to enhance international education and its role on campus.

Dr. Bell has travelled abroad several times as an official representative of the college in the past four 
years. On one trip, he visited the People's Republic of China and Japan. And, on another, he went to the soviet Union and Poland. The purpose of each trip was to consult with national leaders on community college education issues. As a result of the trip to the People's Republic of China, twelve Chinese faculty studied at Shoreline Community college for six months. Other tangible results, according to Dr. Bell, included his presentations to faculty in-service sessions and a deeper understanding of the new global economy emerging and the close ties of people around the world to Seattle and vice versa.

While faculty have been involved in several study abroad programs throughout the history of the college, including one in a semi-permanent location in Mexico, staff, at this time, are being officially encouraged to lead student study abroad projects. Most have been and continue to be, however, funded through private agencies specializing in this arena and through student fees rather than through college funds. One such enterprise, the Mexican study abroad program, met with financial disaster and quickly died. All, however, have set the stage for continuing participation in study abroad programming. As a result, Shoreline has had the most students study abroad in the past ten years: 170 in seven different countries. 
For the past three years, Howard Vogel has been the coordinator of an eight college AIFS study abroad consortium in and around the Puget Sound area. Howard Vogel's efforts culminated in the 1987-88 academic year when he was named international studies coordinator to go along with his social sciences division chair position. He is responsible for the coordination of all study abroad programs carried out in the name of the school.

Also in the past four years, a number of new courses in international studies have been created and are being taught in the social sciences and international education division. The courses parallel the core introductory classes in the Henry M. Jackson school of international relations at the University of Washington. The courses emphasize international economics and politics. Thus, a student can begin his or her preparation for transfer to the University while at Shoreline.

Two years ago a decision was made to increase the number of international students from 200 to 300 in order to continue, as Dr. Bell contended, the cultural diversification of the campus through the international student body. While it was not stated as such by any of the interviewees, the decision was probably prompted by economic considerations as well. The international student admissions clerk, Darline Brent, pointed out that shoreline was turning away 
as many as three applicants for each one accepted. And, with the capped enrollment and cost-covering tuition and fees being borne by the international students as a contract, additional revenues flowed to the school without additional staffing.

With more than twenty percent of the faculty born abroad and with a twenty year history of involvement in international study abroad programming, Shoreline community College boasts the highest number of faculty travelling overseas during the past ten years as well. More than onr. hundred of the faculty have participated in foreign travel, either through organized college sponsored travel or on their own.

\section{Funding and staffing for International Education}

In terms of organizational structure, international education and programs can be found in two basic areas of Shoreline Community college: In the counseling department and in the social sciences and international education division. International education and programming, however, can be found throughout the cultural milieu of the college as a result of the college's overall efforts in this field. For instance, the foreign language department offers five different languages and the humanities division offers a number of courses in world literature. (of the three case studies, Shoreline Community college appeared to the author of this 
dissertation to have integrated international education programming into the mainstream of the campus more so than either Mt. Hood or Edmonds community colleges.)

Funding for international education at shoreline community college is almost entirely funded through program contracting, with students covering most of the direct costs. The three major international education thrusts of the college, 1) international students, 2) international study abroad, and 3) international curriculum, are all funded through student participation. The international travel of faculty and staff have been primarily funded by either the individuals themselves or through the student study abroad programs. Dr. Bell has travelled through the auspices of AACJC and Howard Vogel has travelled through the auspices of AIFS.

International student tuition in 1989-90 was set at $\$ 1,132.00$ per term for a full-time student taking 12 or more credit hours. With 290 international students, the college received more than $\$ 328,280.00$ each quarter, not including additional fees for summer, labs, and books. The college, in turn, provided six full-time ESL instructors (who also instruct resident students who do not speak English in addition to international students), one full-time international student coordinator (who taught one class per quarter), one full-time international student advisor, one full- 
time admissions clerk, and one twenty-five hour assistant admissions clerk.

All international study abroad programming was paid for by student fees. Through a variety of arrangements depending on the private agencies involved, the destination, the number of faculty participating, a study abroad program can be cost covering with as few as eight student participants. Shoreline Community College has averaged seventeen students a year in its study abroad programs. With that many students participating, the home campus coordinator's position, a small part of Howard Vogel's time, was also covered.

The core curriculum for international studies and all other classes designated as international were also funded through students and the taxpayers of Washington state. The state of Washington reimbursement formula reimburses the college whenever a class is filled beyond the minimum number established by the college for cost covering purposes; thus, the international studies and international education classes were, in effect, paid for by students and the taxpayers in the same exact manner as any other regular college class. The Board of Trustees of Shoreline Community College, according to Dr. Bell, does not like to pursue federal grants and external funding as a matter of preference, not necessarily policy. The college has received federal funding in such areas as vocational education, financial aid, 
and other formula grant awards. The college has not received nor pursued federal grants for international education projects thus far in its history. As a result, the college has not participated in any of the available federally funded international programs.

one recent exception to this preferred unwritten policy was the external grant received to hold the Model Arab League Conference. Shoreline community college received a very small grant from the Northwest International Education Consortium to host the Second Model Arab League Conference. Howard Vogel and other staff and students dedicated more than a month of preparation time to host seventeen colleges and universities from the west coast of the United States as they modeled the Arab League deliberations on the Persian Gulf crisis. The small funding was used primarily on advertising, printing, and telephones. According to Mr. Vogel, the conference was an overwhelming success giving Shoreline Community College even further recognition in the field of international education.

\section{Goals and Objectives for International Education}

From the initial survey questionnaire, from interviews and from limited available documentation, it was very clear that Shoreline Community College staff have set modest goals and objectives for the continuation and development of international education. 
In the initial survey instrument, shoreline staff indicated that international education was only a middle priority of the campus. From interviews, the staff, in general, wanted to strengthen existing efforts and make those changes that would result in the fine tuning of existing programs. The interviewees eschewed or rejected any new major thrusts in international education, such as, say, a branch campus in an overseas location or obtaining additional external funding or hiring a new administrator and new staff for either new or existing programs.

There was no documentation for any long range planning or initiatives in international education for the future. The interviews never revealed any specific planning documents or written goals and objectives for international education at Shoreline Community college. Communications about the future appears primarily in private correspondence in the form of memos or face to face meetings. There seemed to be, however, universal agreement that what they were currently doing, which was quite a lot, obviously, should only be fine tuned and slow moderate gains were in order for the future.

\section{Strengths and Weaknesses of International Education}

From every source, the Shoreline community college community of administrators, faculty, staff and students felt the greatest strength of their international education 
efforts have come from the international students recruited and retained on campus. The fact that there are four fulltime staff members devoting their time to international students was perceived to be a strength. The six full-time ESL instructors employed in the education of international students also was perceived to be a strength. In interviews with several of the 290 international students, it was learned that there was a great deal of satisfaction by the international students themselves in the kind of treatment and services available to them.

The steady progress in international education curriculum development was perceived to be a strength of shoreline Community college. The development of study abroad programs and the continuing support given these programs was listed as a strength as well.

Any perceived weaknesses only stemmed from staff not being able to do slightly better at what they do, which is more of a self criticism than an institutional issue. They would all like more resources to do their jobs, which is almost universal within every organization. One person indicated a need to increase the hours of the 25 hour admissions assistant to full-time. There was expressed a hope that the international student counselor position would stabilize as it had changed hands twice in the past three years. And, there was expressed a hope that a change in the 
study abroad program in England would work for the better as Shoreline was entering into an new agreement with an English college rather than continue with AIFS in London.

All in all, the perceived strengths and weaknesses were articulated in very moderate and subdued terms for such an active community college in the field of international education.

\section{The Future of International Education}

Shoreline Community College has set for itself a steady course in the field of international education. To a person, all the interviewees reflected a determination to make international education stronger within the existing structures. No one thought there was any particular need to change or dramatically upgrade the college's efforts at this time. None thought they should backtrack, either. The respondents seemed to speak as though of one voice: The international education efforts of the college have been very appropriate to the educational mission of Shoreline Community college. With close to 320 international students, successful study abroad programs, and international curricula being implemented, the staff of Shoreline Community college seemed most interested in fine tuning what they have rather than add on any untried and/or unknown international endeavors. 


\section{MT. HOOD COMMUNITY COLLEGE}

\section{Introduction}

The following case study of Mt. Hood community college in the state of oregon was compiled through the use of interviews with key personnel during a three week period in April, 1991, and the use of relevant documentation. Interviews were conducted the Assistant to the President for Organizational Development and International Education, the Dean of Instruction, the Registrar, an Instructor for International studies, several international students, and several classified staff members, both in and out of the international education arena. A series of informal discussions were held with the President, Dr. Paul Kreider, over a longer period of time with regard to international education. Documentation included the college catalog, international studies curricula information, college organization charts, international student brochures, recent copies of the international newsletters, and college statistics. (The author of this dissertation is a full-time administrator at Mt. Hood Community College and has had access to all personnel and key documents on an on-going basis.)

\section{Institutional Description}

This large, suburban campus located fifteen miles east of downtown Portland, Oregon, is situated on 250 acres on a 
bluff looking eastward toward a panoramic view of the mountain it is named after. Established in 1966 with the stated goal of providing vocational and technical training for the citizens of East Multnomah County, the college grew rapidly and expanded into a comprehensive community college within several years of its opening. Currently, the college serves three major areas of interest: Vocational-Technical students (34\%); College Transfer (48\%); and, Other Education (18\%). Most of the transfer students go to oregon universities, and to Portland state University in particular. Mt. Hood Community college is the fourth largest community college in Oregon.

Tuition and fees for a full-time student average just less than $\$ 300$ per quarter. The college does not have any dormitories and is an exclusive commuter campus. students come primarily from the local area surrounding the campus, mostly from the city of Gresham, but do arrive in large numbers each day from both eastside Portland and from Vancouver, Washington. Only students living outside of oregon, Washington, and Idaho, including international students, must pay additional tuition. Reciprocal state arrangements have been made with Washington and Idaho to grant students from these states resident fees.

The campus is spacious, with ample free parking, and constructed from poured concrete, giving it a massive ap- 
pearance once you are on the grounds. Boasting three swimming pools, a domed gym, a football field with covered seatj.ng, and baseball and soccer facilities, Mt. Hood Community college obviously had athletics in mind when building began in 1969-70. The first president of the college was a former professional football player, Dr. Earl Klapstein. Football, as an intercollegiate sport, was dropped in 1981, and, according to many veteran instructors at the college, deprived the school of a spirit only found at those college campuses engaged in the sport.

The budget for 1989-90 was right around $\$ 25$ million. Revenues come from four basic sources: Local property taxes; state reimbursements for each full-time equivalent student up to a predetermined number; student tuition and fees; and, grants and gifts. The college failed to secure passage of two property tax measures in 1989, prompting the school to revise its priorities within its funding base, causing a cut in some areas, including instruction, which resulted in six percent fewer classes and sections.

The college is well-known for its music and theater programs, hosting several prestigious, well attended regional conferences and workshops each year. In addition, the college is host to the nationally known Mt. Hood Festival of Jazz each August. Many other programs and activities re- 
ceive state, regional, and national recognition for excellence.

The college is also becoming well-known nationally and internationally for its Japan Center in Kurashiki, Japan. With assistance from Edmonds Community College, Mt. Hood was able to work closely with Japanese business and government leaders from the City of Kurashiki, Japan, to establish a MHCC Center in the southwest part of the main island. In a community of more than half a million and more than 3 million within one hour commute time, the new Japan Center was able to attract 156 students in the first quarter of operation.

\section{Students}

During the 1989-90 academic year, Mt. Hood Community College enrolled slightly more than 6,100 full-time equivalent students. More than 27,000 individuals participated in their education. The ratio of individuals to FTE's was 4.4 in 1989. Women made up the majority of students, with $57 \%$. The average age was about thirty-one, a decline from previous years when it had reached slightly over thirty-three. Most students work while attending school. Thirty-four percent work part-time and thirty-eight percent work fulltime. The student body is very homogeneous with less than nine percent non-white, including those with spanish sur- 
names, which is slightly higher than the community the college serves.

As reported, the college enrolled fifty-three international students or 0.86 percent of the total enrollment. of the fifty-three international students, thirty-five were enrolled in one 2-year program, a federally funded project through Georgetown University and the US Agency for International Development, called CAss. These students were all studying food science technology and came from central America and the Caribbean Basin. Their native languages included English, French, and Spanish. of the other twentythree international students, ten came from Japan and one each from thirteen other countries.

With the opening of its branch campus in Kurashiki, Japan, an additional 156 international students were enrolled. These students, thus far, are not counted in the college's international student totals. Administrators do, however, anticipate larger numbers of Japanese students to take classes on the main campus in the next several years due to extensive advertising throughout Japan and the progression of enrolled students in Kurashiki wanting to transfer to the United States.

\section{Faculty}

There were 163 full-time faculty employed during the 1989-90 academic year. In addition, more than 320 part-time 
faculty taught classes for the college. Males made up the majority of full-time faculty $(61 \%)$. A majority hold the Master's degree, with seven percent of the faculty holding the doctorate. The faculty is a senior faculty with the average person having taught at the college for more than fourteen years. Slightly more than sixty percent have reached the top of the pay scale. Mt. Hood faculty enjoy the highest salaries of any of the sixteen community colleges in the state of oregon (OEA Communicator, Fall 1990), with the mean salary being $\$ 36,258$ and the top of the pay scale reaching $\$ 40,208$, excluding fringe benefits or a differential for the doctorate.

Teaching loads are established by contract at fifteen Individual Load Credits (ILC's) per quarter, which for the typical transfer studies instructor is five classes at three credit hours each. Because of loading factors based on split lecture, seminar, lab, and field work assignments, vocational instructors have complicated formulas to determine their individual work loads, although fifteen ILC's is the standard to which everyone adheres. Faculty can teach up to nine ILC's for extra pay each year, which many opt to do.

Mt. Hood Community College officials estimated that they have six faculty members who were born in a foreign 
country. Thus, less than four percent of the faculty have brought an international experience to their teaching by virtue of their birth. Five full-time instructors (3.1\%) are from minority backgrounds, one of whom is also foreign born. Like the student body, the faculty is also homogeneous reflecting the Anglo make-up of the state of Oregon, which is about three percent non-white.

Through active participation in the Fulbright-Hays Summer Project Abroad program during the past ten years, thirty faculty and administrators have lived and conducted research in one or more foreign countries. This one program accounts for a significant "internationalizing" of the faculcy.

\section{The community}

The major population center of the City of Gresham and East Multnomah County runs southwest of the main campus. Further to the west is the metropolitan area of Portland, while Vancouver, Washington, is northwest and just across the Columbia River on a recently completed Interstate Highway. Because district or residency requirements are no longer in force, Mt. Hood Community college serves a potential market of several million people in the Portland metropolitan statistical area. However, Portland Community College, Clackamas Community College, and clark Community College (in Washington State) offer similar educational 
services in the most highly populated areas. While most faculty and staff at Mt. Hood perceive that they are a part of the metro area, the focus of issues tend to be on what people in Gresham and the immediate surrounding area might think about them. This is a natural outgrowth of a dependency on local tax dollars and with local property taxes supporting forty to forty-five percent of the operating costs of the college.

Gresham has been undergoing a transition from a lumber and agriculture based economy to a suburban bedroom and industrialized based economy as the city limits have moved more westwardly with the annexation of county property into City of Gresham. In addition, an urban light rail system was completed from downtown Portland to Gresham as the east terminus in 1986. Light, clean air electronic firms have recently located in Gresham, causing an apartment and housing building boom. The Portland International Airport is a part of the Mt. Hood district, and Gresham became the third largest oregon city in 1988. Thus, long-time residents of Gresham and senior staff of Mt. Hood Community College are struggling with a new identity and a major break from the past. One of the people interviewed said, "Gresham is fifteen miles away and fifty years behind Portland" in their thinking about themselves and their role in the world. 
Another staff member thought of Gresham as still being a "rural community."

As the metropolitan area and the "global village" have crept into the thinking of the people of Gresham and the staff of Mt. Hood Community College over the past ten years, the community and the college have struggled to find their place in the new order of things. Many do not want to let go of the past and do not want to participate in worldly affairs and wish for a return to the time when Gresham was a small town and lumber, agriculture, and high school and community college football were the most important things to be concerned about.

It is in this context that decisions about international education and reaching out to the rest of the world have been made at $M t$. Hood Community College. Nevertheless, Mt. Hood Community College was the most active of the oregon community colleges and the third most active among all community colleges in the two state region of oregon and Washington states from the data received in this study.

\section{College Structure and organization}

Mt. Hood Community College has one main campus, two centers within the district, and one center in Japan. The district is headed by a seven member Board of Education elected from sub-districts and areas within the college's district boundaries determined by political precincts estab- 
lished by the state legislature. Board members serve for four year terms. The Board sets all policies and leaves to a twenty-nine member Administration the rules and regulations by which the college is organized and operated. The president, Dr. Paul Kreider, has been in office since April 1986. There are four deans: A dean of instruction; a dean of student development; a dean of community and vocational development; and, a dean of administration. While there is a dean of instruction, the dean of student development and the dean of community and vocational development also have instructional responsibilities. The dean of administration is the chief business officer for the college.

There are a number of associate deans responsible for specific instructional and student development areas. In addition, the college employs directors for the three offcampus centers. The Director of MHCC-Kurashiki Center, which only began operating in April of 1990, has been more or less reporting to the president, who directs tasks to any of the administrators needed to resolve an immediate issue or crisis. Other directors, who report to the deans, include one for financial aid, athletics, and the physical plant. There are two assistants to the president, one for organizational development and the other for college advancement. Three others report directly to the president: 
The director of personnel; the director of research and computing services; and, the director of development (a joint appointment with tine MHCC Foundation).

There was no one person charged with the primary task of organizing and directing international education. The assistant to the president for organizational development chairs a seventeen member administrative international education steering committee, which was created in early 1989. This committee meets twice a month for two hours to deliberate on current issues and future directions for any international education activities. A second committee, a faculty steering committee, created in late 1989, chaired by an English instructor, and composed of about twelve members, meets twice a month for similar purposes as the administrative international education steering committee. One administrator sits with the faculty committee and the faculty chair sits with the administrative committee. The two groups had never met in a formal session together, although individual members of both groups attend many of the same international education functions and activities.

With the defeat of two property tax measures during the 1989-1990 academic year, there were no significant additions or changes in the administrative organization chart with the exception of the addition of a new director and assistant director for the Kurashiki Center in Japan. 


\section{History of the International Education Programs}

From interviews and documents, the history of international education programs at Mt. Hood Community college is as old as the college itself. For the first ten years of the college's existence and under the tutelage of the founding president, Dr. Earl Klapstein, international education was encouraged but not necessarily practiced. The college community was busy establishing a new enterprise and faculty and staff, for the most part, ignored international education. One could say, as one interviewee said, "it suffered from benign neglect." Another staff member interviewed suggested that the founding president probably envisioned a role for the college in international education but wasn't particularly interested in it himself.

In 1977, however, sixteen Nigerian students came to Mt. Hood Community college as part of a major international education project sponsored by the AACJC. Apparently, no one in the college or in the community was really prepared for the arrival of these sixteen international students. Nor was the government of Nigeria really prepared to assist their own citizens sent to the United states for a two year college education.

Without an office of international education and without a full-time international student advisor, the sixteen black Nigerian students, underfunded and without much gov- 
ernment or parental guidance, struggled to meet their educational goals at Mt. Hood Community college. To veteran staff at the college, the two year Nigerian experience set the tone for all future encounters with international students. As recently as 1987, Mt. Hood Community college had only eight international students in attendance out of a student body of more than 24,000. As the former dean of student development argued, "without adequate support staff, we (MHCC) do not want to be 'ugly Americans' and not provide for the welfare of our student guests." So, without college funding nor the will to change priorities, Mt. Hood Community college shunned any opportunity to acrively recruit international students.

The college was, however, more active on other international education fronts. Through the efforts of a new president, Dr. Stephen Nicholson, and several dedicated faculty members, Mt. Hood began its involvement on three fronts: internationalizing the curriculum; international business and trade; and, Fulbright-Hays summer study Abroad Projects.

A former employee and instructor of spanish, Tilly Harris, who was born in Greece, became involved in several international education consortia arrangements with the blessings of her division chair, Margaret Gratton, and the top administration. Her efforts, and those of the former 
development director, Paul Tollinen, resulted in several grants coming to Mt. Hood community college in the late 1970 s and the early 1980s. Ms. Harris directed two Fulbright-Hays Summer Study Abroad Projects, one to Peru and one to Taiwan, Hong Kong, and Thailand in the Far East. These trips involved more than twenty faculty and staff in the creation of "international education learning modules." The modules are lesson plans that can cover up to six hours of lecture and seminar materials on different topics from different countries visited by Mt. Hood staff. Today, there are more than seventy modules in the MHCC library for staff and others to use on a lending basis. The modules are used mostly by faculty in international studies. Faculty in other areas check them out on a more irregular basis.

With several others from the business division, Ms. Harris assisted the college in securing a us office of International Education Title VI(b) Business and Trade Education grant in 1983. This grant established the existing International Business and Trade program still in existence today. She was also instrumental in bringing internationally known speakers to campus, including Seymour Fersh and Maxwell King. For her efforts, she was given released time from her teaching and the "unofficial" title of international education coordinator. In 1985, Tilly Harris left 
Mt. Hood to pursue a doctorate at George Washington University. She submitted her resignation after assisting the college once again in getting a Fulbright-Hays Summer Abroad Project in Costa Rica for 1988.

With the departures of Dr. Nicholson and Tilly Harris, the retirement of Paul Tollinen, a down-turn in student enrollments, and the expiration of the Title VI(b) grant in 1984, international education at Mt. Hood Community College fell into "benign neglect" once again.

During the 1988-1989 and the 1989-1990 school year, several factors came together that would provide a huge impetus for international education programs at the college. student enrollments were growing at double digit rates, the above mentioned Fulbright-Hays grant to Costa Rica was awarded, the Fujitsu Electronics Company opened a major manufacturing complex in Gresham, several new associate deans and directors were hired from other schools where international education was a higher priority, Margaret Gratton became the assistant to the president for organizational development, a Central American and Caribbean Basin food science technology program for thirty-five students was begun, a full-time English as a second language instructor, Perry Rikli, was starting his second and third years at the college, a new dean for student development was hired, and a Japanese business group gave the college an unprecedented 
opportunity to open an American community college center in Japan. All of these efforts revitalized international education programs and activities at Mt. Hood Community College.

Bringing international education back to life was not without its problems though. As international education expanded to include more international students, travel for faculty and staff to overseas destinations, and the creation of an educational center in Japan, criticism was directed at college administrators by the local press and some factions of the faculty for supporting programs that drew attention and, perhaps, funding away from the local community of Gresham. More than one interviewee pointed out that, rightIy or wrongly, criticism received both in the Gresham and Portland newspapers may have contributed to the election losses for new property tax support. The president and others dismiss this analysis by pointing out that oregonians, in general, are against higher property taxes, period. Nevertheless, the public criticism caused some glee among those who would just as soon not have a center in Japan or do educational business outside of the local district boundaries. The critics point out that a community college should stay in the community. Since the beginning of the 1990-1991 academic year, when these interviews took place, a state-wide tax revolt in 
the form of a 1.5 percent property tax limitation, known as Measure Five, was passed by the voters of oregon. IronicalIy, with the passage of measure five, Mt. Hood Community College became more reliant on state funding and less on local funding. Political power and influence was shifting away from local control to state control. State government officials, particularly the former governor, Neil Goldschmidt, and the former assistant superintendent for public instruction responsible for community colleges, Michael Holland, have supported the idea of an oregon community college operating in Japan. And, whether it was by design or not, the timing for passing a new mission statement in the fall of 1990, which committed the college to teaching about things of the world and that students, faculty, and staff should participate in the growing global economy, the timing couldn't have been better for the advocates of international education.

\section{Funding and Staffing for International Education}

The largest international education activity at Mt. Hood Community college indexed by student numbers and dollars was the new Japan Center. The MHCC Kurashiki Center is being funded entirely by Japanese business leaders in the Yokohama prefecture.

Begun in April, 1990, Mt. Hood Community College hired one director, one assistant director, one administrative 
assistant, and seven ESL instructors for the first year's operation. All of the staff were new hires, which has caused some problems in the sense that no one from MHCC went to Japan with a clear understanding of the main campus and the way busiriess is done at home, much less in Japan. Instruction for the first 156 students in the first year started in an eight story office building in the suburb of Kojima, located virtually at the foot of the seito ohashi Bridge, which connects the main island of Honshu with the southern island of Shikoku. At the beginning of the second full year of operations in April of 1991, a new two story campus building in Kojima was opened with 177 students. Students pay about $\$ 7,500$ annually for their education. Mt. Hood Community College is reimbursed for all costs of the Center. Plus, the college receives five percent of all tuition and fees collected; thus, the project is creating a new source of revenue in an otherwise difficult economic time.

The Central American and Caribbean Basin food science technology project with thirty-five students receiving instruction on the main campus is staffed with one nonadministrative coordinator, one assistant to the coordinator, one half-time counselor, and one half-time administrative assistant. According to the coordinator, the project is every bit as much involved with "experiencing America" as 
it is with classroom instruction. Therefore, one full-time person is charged with the responsibility of extra-curricular activities for the two groups of students (one started in August of 1989 and the second in Januaxy of 1990).

The budget for this project requires some cost-sharing, although the college's share is matched with in-kind tuition waivers and space while the project reimburses for actual costs. The project generates about $\$ 1,000$ per student per month with more than half going to the student directly for room, board, and expenses. All the students were placed in home-stays with local "parents" receiving $\$ 250$ a month. The rest of the budget is in staffing and training. The college receives eight percent for administrative costs. The project created another new source of revenue for the college as it generates more money than is spent.

The college has been moving toward full-time staffing in the area of ESL and ENL instruction. In 1986, a fulltime ESL/ENL instructor was hired. Prior to that only parttime instructors were used in this area, which still accounts for the majority of ESL teaching.

International business and trade classes taught in the business division and international studies classes taught in the language and literature division are budgeted through regular divisional funds. Classes without sufficient enrollment, like any other class, are, of course, canceled. 
The international courses are taught as small parts of several full-time instructors' loads.

Because so much of the work of international education is done by committee and as add-ons to regular assignments at Mt. Hood Community College, it is difficult to know exactly how much the college has directly committed to international education programs and activities. There are a few support services in the college where staff have been directed to give a percentage of their time to international education. One full-time advisor has ten percent of his time designated to international student advising and one half-time admissions clerk devotes most her time to international admissions. The rest of the international programming, including foreign speakers, study abroad programs, and other international activities are all done as both a labor of love and as an outgrowth of regular assignments.

\section{Goals and objectives for International Education}

Mt. Hood Community college has been engaged in planning through the processes of strategic planning for the past six years. Each unit of the college submits an annual detailed plan that is reviewed by a strategic planning council and the Board of Education. For two years, beginning in 1989, the Administrative International Education steering Committee has submitted a strategic plan for college-wide consid- 
eration of goals, objectives, and funding for international education.

The following goals and objectives were articulated in the 1990-1991 Mt. Hood Community College strategic plan developed by the administrative steering committee for international education:

This strategic plan outlines how the college is fulfilling this mission and how it might strengthen such efforts.

1. International Curriculum and Programs.

The International studies Curriculum, the World View lecture series, and foreign language classes are offered through the Language and Literature Division. The Communications Division offers intercultural communication classes, while the International Business degree program is housed in Business and Computer Technology. Hospitality and Tourism is offered through the center for Community and Economic Development. The Peace studies curriculum, classes on international terrorism, and other internationalized courses are found in the Social sciences Division. Internationalized teaching units are available through the library; however some are in need of revision and updating. Although individual faculty are present in these respective divisions to talk with students and advise them about international curriculum and programs, there still is no central source for students to be advised generally about international. study. In 1989-90 the steering committee develop a 1990-91 catalog page which listed all interr:aisisnal/internationalized courses and gave students better direction in planning for international study.

2. Committee on International Education.

During Spring term 1990, the Administrative steering Committee created a sub-committee of faculty and student services personnel to monitor curriculum, programs, and activities which pertain to international education. The purpose of the newly formed 
committee includes evaluation of the cohesiveness of MHCC courses and review of the application process, advising, and other support services for international students. It is expected that staff input through this sub-committee will be a continuing resource for the Administrative Steering Committee.

3. Study Abroad। Program.

MHCC continues its relationship with other colleges in the oregon Community college consortium in cooperation with| American Institute for Foreign Studies to sponsor al spring quarter in London. Work on this effort is coordinated through the office of Instructional Services and Language and Literature. In addition, the cooperative education/internship program is working with the Northwest International Education Association for developing coop ed positions abroad.

4. International students and services.

MHCC has been the educational site for several Amerjican language study programs offered each summer for Japanese high school and college-age students. In summer 1990, MHCC hosted 23 students from Hokkaido Women's College in Ebetsu, Gresham's sister city, Hokkaido Women's College has a sister-college relationship|with MHCC.

Many requests for training and language skills come to the college, arriving in different offices, and channeled through different resources. clarity is needed regarding the college's position in sponsoring rumerous summer language studies and joint sponsorship for training.

Discussions continue regarding long-range planning for building the college's capacity to serve international students. It is clear that international students must be served by a well-designed infrastructure within the college and community. A major barriex to implementing such a support system is lack of sufficient staff and funds. student services is considering what sort of international student fee could help provide funding for proper support, as well as other policies and procedures which might result in stronger support for international students. 
5. CASS.

Since Fall 1989, the college, in partnership with Georgetown University and the U.S. Agency for International Development, provides training in food science technology for Central American and Caribbean students. Program and student expenses are funded through the Cooperative Association of states for Scholarships (CASS). This group of students will remain at MHCC for two years of training and then return to their own countries. Many local families provide homestay opportunities and a 20 member college/community advisory committee assists in implementing the program. Administration for the CASS program involves the Associate Dean of student Activities, the Associate Dean for Science, the Associate Dean of Advising and Counseling, as well as coordination through the Developmental Education program.

5. MHCC in Kurashiki.

The MHCCK Center opened in April of 1990 and now serves 150 students. In the Fall of 1990, a new contract for 1991-1992 was developed and the staff embarked on its first round of strategic planning. In september, ground breaking ceremonies were held for a new building, which can serve up to 500 students in the future. The Kurashiki program is stable, however MHCC presence in Japan has sparked controversy in the press and has raised questions about the college's capacity to serve students both at home and abroad.

To date over $\$ 60,000$ has been contributed to the college for administrative services, in addition to support for travel and MHCC staff days in Kurashiki.

6. Hokkaido Women's College.

Also in September 1990, the MHCC board approved a draft agreement for student and faculty exchange with Hokkaido Women's College in Ebetsu.

7. Sister-Colleges.

The college continues sister college relationships with Hokkaido Women's College in Ebetsu and Dong U College in Sok Cho, Korea. 
8. Grants.

MHCC has filed a Fulbright-Hays Faculty Group Project Abroad grant which would support 10 faculty to do research in Brazil in the summer of 1991. Upon their return, they will produce international teaching units and conduct global studies workshops for district $\mathrm{K}-12$ staff.

9. Community Outreach.

In the spring of 1990, the college signed an agreement with the Gresham Area Chamber of Commerce to co-host periodic international community forums. In the near future, several community leaders will be invited to serve on an MHCC Kurashiki advisory committee.

10. Organizations.

MHCC maintains active membership in the Northwest International Education Association with a position on the board.

The college is a founding member of the Educational Partners for International Cooperation (EPIC). This organization holds regular conferences and has established links with the National Taichiung Institute of Commerce in Taichiung, Taiwan, and the National Taipei Institute of Technology in Taipei.

The college also belongs to the oregon International Council. Membership dues come from several specific units without a central source. These include president's office, and staff and organizational development. Most recently the college became an affiliate member of community colleges for International Development (CCID).

11. Strengths and Weaknesses.

At this time the greatest institutional strengths in international programs are diversity of effort, enthusiasm and energy on the part of staff for moving ahead, and a fairly broad base of expertise. This dedication has been enhanced by the college's inclusion of global education and partnerships in the central mission. Institutional momentum remains constrained however, by no specifically designated institutional budget for organizational efforts. 
The steering committee has the potential to set direction, but operates without a fiscal foundation. In addition, current efforts require more support services than are available. The strain on human and fiscal resources continues to prompt questions about how far the organization ought to extend itself to international partnerships and international students. Clear communication and broadbased discussion on the issues will be imperative in the coming months.

Given the current momentum, the college is well positioned to make major contribution to international endeavors, but a coalescing of staff support is needed.

The Administrative steering Committee for International programs plans to develop a proposal for institutional staffing and funding to best serve the existing and developing institutional needs in international efforts.

A. Objectives which can be achieved within existing resources:

1. Support a comprehensive budget unit for institutional international efforts;

2. Continue to support ways for instructors of international/internationalized courses to communicate across disciplines on a regular basis;

3. Support effective communication systems to keep all staff well informed regarding international programs;

4. Have in place a system for advising students with general interest in international studies;

5. Continue the Administrative steering Committee for International Programs;

6. Continue the Committee on International and Intercultural Education;

7. Monitor and support major institutional programs such as MHCC in Kurashiki, CASS, and London Study Abroad;

8. Encourage and endorse staffing, funding, and organizational recommendations to serve the existing needs in international efforts;

9. Continue to explore existing external resources such as Fulbright-Hays Faculty Group Projects Abroad; 
10. Work cooperatively with the Gresham Area Chamber of Commerce to hold international forums in the community;

11. Provide on-going professional development programs directed toward serving international students and cross-cultural training; and,

12. Maintain membership in international organizations, such as Northwest International Education Association, oregon International Council, EPIC, and Community colleges for International Development.

B. Objectives which will require additional resources:

1. Establish the position of director of international programs, which will carry the primary responsibility for coordinating institutional international programs, planning, and partnerships;

2. Implement an infra-structure for responding to requests and needs of international students which will assist them in full participation in campus life;

3. Support the Fulbright-Hays Faculty Group Projects Abroad in Brazil grant (approximately $\$ 10,000)$;

4. Support plans for an infra-structure to recruit, support, and serve foreign students, including revision of the international student fee;

5. Develop, coordinate, and support more diverse opportunities for student travel abroad, membership in organizations; and,

6. Develop an International Resource Center for International Education.

The above statements are verbatim from the Mt. Hood

Community college strategic plan for 1990-1991. They incorporate the best thinking of the international steering committee and those currently involved in any or all aspects of international education for the campus. 
Strengths and Weaknesses of International Education

The strengths of the Mt. Hood Community College effort in international education are many. The college administration and board of education have stated unequivicably in a new mission statement that the college must be involved in a "global community (and the college) shall cultivate international understanding through education and partnerships." The verbal commitment is, obviously, present.

The current decentralized approach to conducting the business of international education and programs across the campus results in the involvement of a significant number of administrators, faculty, and staff. Thus, it appears that there is a broad base of support for current and future programs in the field of international education.

The development and creation of learning modules in international education allows any instructor to have access to a variety of topics and issues that might be incorporated into any class being taught at the college. Mt. Hood is a national leader in this novel approach to "internationalizing the curriculum."

The college has been very active in obtaining Fulbright Hays Faculty Group Pxojects Abroad grants with three in the past ten years and a fourth application in process. As a result, the college boasts more than thirty faculty and staff who have lived and studied abroad from a total faculty 
of 163. The college has been open to other externally funded projects, such as the CAss program.

There is a developing relationship between the college and the community in the field of international education. The lecture series, the creation of a Japan campus community advisory board, and sister-college relationships with colleges in the Gresham sister-cities are but a few examples of this cooperation.

The development and operation of a foreign branch campus in Japan is a major step in providing leadership in an emerging global society. The risks of operating such a Center are very great; but, the rewards and satisfaction are likewise very great.

The curriculum of the college, such as Peace studies, World Civilization, Intercultural Speech, International Studies, International Business and Trade, International Relations, five different foreign languages, ESL/ENL, and others, indicates a strong interest in providing students an opportunity to explore and understand the world.

In a way, the major strength of international education at the college is also its major weakness, too. That is, the decentralized efforts in this field leaves a huge need for coordination. Everyone is in charge; thus, no one is in charge. Many opportunities have bypassed the college simply because of a lack of full-time leadership. It is rarely 
possible for an outsider to know exactly who should be contacted regarding international education. Sometimes, it isn't possible for insiders to know just where to turn to for assistance either in creating or resolving issues in the field of international education. There is no permanent office or full-time person given the ultimate responsibility of heading up international education programs and activities.

This weakness is particularly noticeable in the college's efforts to coordinate the new Japan campus. With every employee of the Kurashiki campus hired from outside, the staff in Japan has been unable to know exactly who to correspond with in matters of, say, instruction (the Dean of Student Development, for instance, is in charge of ESL), business matters, or policy matters. The president of the college has had to take on the task of being the campus coordinator for the new Japan Center delegating assignments across campus to solve immediate issues and crises.

Along with a lack of full-time leadership is the lack of district funding for international education programming. The college has distributed its funding for international education across the campus in the form of supporting the instructional efforts of individual faculty and staff. There are monies in the budget for memberships, staff development in the context of international programs (i.e., the 
Fulbright-Hays projects), and other items distributed to different offices around campus, but the college lacks a centralized funding source for existing and new efforts in this field. External funding, of course, is directly applied to the externally supported program, such as CASS. A line item budget for international education is missing from the budgeting process at Mt. Hood Community college.

The low number of international students at Mt. Hood Community college would suggest a lack of interest or ability to recruit and support students from around the world. Without an international student advisor or other support staff, a foreign student attending Mt. Hood is mostly on their own. As a result, the campus is nearly barren of cultural opportunities both for the international student and the native student of Gresham. The latter being the worse off in the exchange. The strategic planning document for international education does indicate a "long-range" planning effort for bringing international students to campus. It would appear, then, that this is still a low priority for the college when it comes to international education programming.

The number of officially sanctioned opportunities for a Mt. Hood Community college student to study abroad has been limited to only one, the London quarter. The London Quarter was developed for students and faculty for each of the past 
two spring quarters. Organized by a consortium of oregon community colleges and developed and advertised through the Language and Literature Division of Mt. Hood, the time and effort expended versus the participation has resulted in the cancellation of the program for spring 1991. While not many community college students participate in such programs, the number of opportunities, now none, severely limits any growth in this important aspect of a student's education.

On balance, though, Mt. Hood Community college is still very much a leader in international education amongst the oregon and Washington public community colleges.

\section{The Future of International Education}

International education at Mt. Hood Community college is just on the verge of becoming a major element in the life and culture of the school. From interviews and documents, it is clear a critical mass is rapidly approaching that will bring about significant changes in the way Mt. Hood Community College perceives of itself and how it is likely to fit into the global community it strives to be a part of.

\section{SUMMARY}

The three case studies above are an in-depth look at the quality of international education programs and activities at three of the most developed public community colleges in the states of oregon and Washington in this field. 
These case studies can provide a tool for evaluation of existing international education programs or as a tool for the implementation of new and innovative international education programs at those schools not currently involved. 
CHAPTER VI

CONCLUSIONS AND RECOMMENDATIONS

The purpose of this research project was to accomplish at least five objectives. The first objective was to demonstrate a new and original taxonomy of ten elements, or dimensions, found in defining and describing international education. The second objective was make a contribution to the body of knowledge and research on international education practices at the nation's community colleges through an extensive literature search and original research. The third objective was to identify and describe the current practices of international educational programs at the forty-three public community colleges of Oregon and Washington states. The fourth objective was to select three of the most highly developed community colleges from those surveyed and conduct in-depth case studies. The fifth, and final objective, was to provide several conclusions and recommendations discerned from the strengths, weaknesses, and contributions of the oregon and Washington community colleges to international education practices.

The following conclusions and recommendations are based upon the use of the new and original taxonomy and an analy- 
sis of the data obtained through the methods described in earlier chapters.

The taxonomy on international education was especially created for this study to assist the author, and others, to clearly define what people meant by the term international education. There was, and probably still is, little agreement on exactly what people mean when they speak about international education. The taxonomy, with its ten elements, allows people to organize their thoughts and articulation about the subject. When a person can clearly identify that there are at least ten different activities associated with the term international education everyone can be in agreement about the meaning. The new taxonomy was used to organize the literature search. The ten elements of the taxonomy also were used to construct the survey questionnaire and to examine the weighting system used in evaluating the data results.

The responses to the initial survey questionnaire sent to all forty-three public community colleges in oregon and Washington (discussed in Chapter IV) and the case studies on three of the most highly developed community colleges in the field of international education (discussed in Chapter $V$ ). The study propositions or hunches (raised in chapter III) provided the focus for the conclusions and recommendations offered below. 


\section{A REVIEW OF THE STUDY PROPOSITIONS}

Robert Yin (1989) argues that the inquiry must go beyond the specific research questions in order to dixect the study in the path of suppositions, hunches, or assumptions behind the questions. "Each proposition directs attention to something that should be examined within the scope of the study" (p. 30).

This dissertation concentrated on the following propositions: The international education programs and activities of oregon and Washington community colleges evolved and developed through:

1. The efforts of strong presidential leadership;

2. Large community colleges found in urban areas;

3. The presence of international students;

4. The presence of full-time international education administrators;

5. The presence of international education grants from external funding sources;

6. The presence of a strong global curriculum;

7. The presence of strong foreign language programs;

8. The presence of full-time faculty and staff born in other ccuntries;

9. The presence of full-time faculty and staff who have lived and travelled abroad.

A review of these study propositions and some insights into their validity are addressed below. 
Presidential Leadership

The presence of strong presidential leadership, as was observed in the case study of Edmonds Community College, can provide all the impetus, encouragement, and financial backing a campus faculty and staff needs to bring about a strong, viable, and highly visible international education program. But, as was also observed at the other two community college case studies, a presidential endorsement alone, without the constant encouragement and financial backing, may also be sufficient to bring about a strong, viable international eduction program, too.

This study was interested in knowing whether a highly developed community college international education program, relative to all the others in the oregon and Washington region, would need strong presidential leadership at the helm to produce such programming. The adjective, strong, is, obviously, relative; however, for purposes of this study it meant a high level of involvement in practically all aspects of an international education presence on campus. Therefore, the answer seems to be no. strong presidential leadership is not a requirement or necessary for the development of a visible international presence on campus. Yet, the opposite proposition or hunch, a campus interested in international education can become highly developed without the presence of presidential leadership through, at 
the very least, endorsement of the concept, isn't true either. Campus faculty and staff can, indeed, sustain an interest in a certain programmatic area without presidential endorsement. However, for an international education program to evolve and fully develop, it will, indeed, require either passive or active endorsement of the president of the college.

The case study interviews all pointed out that without the active participation of one or two faculty and staff, who struggled to bring the concept to campus and to keep it alive over a long period of time, the international education programs found to be highly developed today would not have happened. Shoreline community college achieved its high profile primarily through the recruitment and retention of international students and study abroad programs. These two thrusts were developed early on in the history of the college by one staff member, an international student counselor. Mt. Hood Community College achieved its high profile primarily through its many decentralized international curriculum activities over a long period of time that were first initiated by one staff member, a Spanish language instructor. Even in the case of Edmonds Community College with its current high profile in international education programs, one or two staff members made a difference in keeping alive the idea of international education in the 
early years that made it possible for a new and very dynamic president to bring to the campus an extremely ambitious program in this field.

\section{School Size and Location}

Because of the variety of international activities possible under our working definition of international education, the proposition that the large community colleges in urban areas would be more likely to have highly developed programs, did not prove to be the case after all.

Interestingly enough, the three campuses with the highest profile in international education and programs were all suburban community colleges with enrollments only slightly larger than the mean $(3,980)$ of the thirty respondents. They were not among the largest of the schools in the region. The fact that there is an inverse ratio between number three, Mt. Hood with 6,100 student fte's, and number one, Edmonds with 4,500, also seems to reject the proposition or hunch. The number two school, Shoreline community College, had 4,400 student fte's in 1989-90, and is very close in size with Edmonds Community college.

\section{The Presence of International students}

One of the strongest held propositions or hunches held prior to conducting this research and after a review of the literature was the belief that the presence of international 
students would propel any community college into becoming a high profile community college in the field of international education. After the data were collected, only two of the three institutions selected for case studies had significant numbers of international students. Edmonds Community college and Shoreline Community college, indeed, each had large numbers of international students. The former with 620 and the latter with 310 during the 1990-91 academic year.

The third most highly developed school, Mt. Hood Community college, by contrast, had very few international students. In fact, if the Mt. Hood CASS program, which was responsible for 35 of the 65 international students on campus in 1990-91, were eliminated from the data, Mt. Hood would have had an international student body of only 30 . Thus, the proposition or hunch was not confirmed, for it is surely possible to be among the most highly developed international education community colleges without having a large international student body. The community college that wants to be engaged in a variety of international educational activities without bringing international students to campus can still be a leader in this field. Such is the case at Mt. Hood Community college. Yet, the case study visitations led this researcher to conclude that the presence of international students on campus enriches international education by virtue of the human resources present 
in daily contacts. How much richer would the Mt. Hood Community college program be if they had 300 or more international students on campus?

The Presence of International Administrators

The assumption behind the proposition or hunch about the presence of international education administrators was the thought that each of the highly developed campuses would have, perhaps, one or more full-time administrators responsible for all aspects of international education. What was found, however, was a myriad of organizational arrangements to account for international education programs.

Edmonds Community College had the most elaborate organization for handling international education. Because they nave a campus in Japan as well as a number of significant programs and projects on the main campus, Edmonds had four full-time administrative staff members devoting their energies to international education: A vice president and a dean of instruction in Japan; an instructional division director for international education and ESL; and, an associate dean for international student services responsible for international student services, ESL and many other international projects. Edmonds Community college also had the equivalent of another full-time administrator attending to international education without it appearing in the organization chart: the president of the college. In addition, Edmonds had the 
highest number of faculty and classified staff devoted to international education programs with the equivalent of ten full-time persons, mostly in ESL.

Shoreline Community college had the smallest number of administrative staff devoting in whole or in part their time to international education. They had one instructional division chair, a full-time administrator, who spent about twenty percent of his time on international education, primarily in the area of study abroad programs and curriculum. They had one full-time coordinator for international student admissions and advising, a full-time member of the faculty, and several classified staff members working in the area of international student advising. Several full-time faculty devoted varying amounts of their time to international education programs.

Mt. Hood Community college, which also has a campus in Japan, listed three full-time administrators responsible in whole or in part their time to international education. Two were assigned to the Japan campus full-time and one administrator on the main campus had ten percent of her time devoted to international education in addition to her duties as assistant to the president for organizational development. Mt. Hood has several full time classified staff members who coordinate the CASS program, as well as several full-time faculty devoted to international education. 
If the two Japan centers were eliminated from the data, only one of the three most highly developed community colleges, Edmonds, would have had one or more full-time administrators responsible for international education. Thus, the proposition or hunch about the role of full-time administrators heading up active international education programs must be rejected. From the entire study, the data reveal that a two state regional meeting of all full-time international education administrators could be held in a telephone booth, and they would both be from the same school. Thus is the state of commitment to the administration of international education programs full-time in the community colleges of Oregon and Washington.

\section{The Presence of International Education Grants}

Two community colleges, North Seattle and spokane Falls, were the leading recipients of federal international education grants in the two state region. While these two schools were not among the three most highly developed for inclusion in the case studies, they were among the top six campuses in oregon and washington states in the field of international education. After reviewing the three case studies, however, all three of the most highly developed schools fully utilized grants and exiernal funding for their respective programs.

Funding for international education programs and activ- 
ities other than from local or state funding sources is readily available. This study reaches the conclusion, without reservation, that if community college personnel want to develop international education programs they can do so with little use of its own monies from the regular operating budget.

International students, as was the case at Edmonds and Shoreline, more than pay for the services and instruction they receive in return. International projects, such as the CAss project or overseas campuses, are fully funded from external sources at both Edmonds and Mt. Hood. In fact, all three of the most highly developed schools made money from their international projects, international students, and overseas campuses and put it back into the general fund for use in either other international projects or projects not connected to international education.

It was very revealing to learn that all three campus presidents were very quick to point out that, indeed, the international education projects were cost covering or making money for their schools. Mt. Hood community college, in particular, goes to great lengths to make sure that in every college news release prominent mention is made of the fact that these programs are in operation without any "taxpayers" dollars being used. Only one of the three presidents interviewed, Tom Nielson of Edmonds Community College, 
seemed determined to advance international education in the same way they might advance, say, welding or writing programs. From this investigation, it can also be concluded that international education and international programs in their own right have not arrived as legitimate programming at the region's community colleges.

Yet, with the presence of so many different grants and externally funded opportunities in this field, community colleges can, if they so choose, become involved in international education rather quickly. The proposition or hunch about the presence of grants and externally funded programming for international education was readily accepted.

The Presence of a Global curriculum

The evidence of the presence of a "global curriculum" from the survey results and the case studies was not particularly strong. One community college, Mt. Hood, has an exemplary track record in the "internationalizing of the curriculum" dating back to the late 1970's. The staff of Mt. Hood Community college through the years has produced more than seventy international education teaching modules available to others through the library on a check out system. These modules can then be incorporated into the curriculum of any instructor wanting to take the time to adapt them to his or her classroom activities.

All three campuses offer an International studies 
program designed for the transfer student. Interestingly, none of the three programs emphasized similar curricular issues. Shoreline community college designed their program to match the University of Washington's Henry M. Jackson School of International Affairs. Edmonds Community College students receive instruction more closely aligned with international business, while Mt. Hood Community College's international studies program is interested in global problems, such as population control, ecology and the environment, and war and peace.

In all three cases, the evidence obtained suggests that these courses and programs are not particularly popular with students and do not attract great numbers. However, the dedication of the faculty teaching in these courses and programs provides strong impetus for other aspects of a high profile and developed international education program. Thus, the proposition that the presence of a global curriculum supports the evolution and development of international education programs is only partially accepted.

The Presence of Foreign Language Programs

Every community college in the study offered two or more foreign language classes. Every community college in the study offered Spanish as a foreign language, save one, clatsop community college. The thirty colleges offer twelve different languages and more than a thousand sections each 
year of both credit and non-credit foreign language classes. It is probably a txuism that the mere presence of foreign languages on a campus adds to the teaching and understanding of internationalism. The evidence gathered from this research, however, did not indicate that either the administrators responsible for foreign languages or the faculty teaching in the field are today particularly active in the evolution or development of high profile international education programs. Mt. Hood Community college was an exception, though, as one Spanish teacher almost singlehandedly kept international education alive for about five or six years through the late 1970's and early 1980's. She is, however, no longer at the college.

The research did show, as well, that the greatest number of foreign languages being offered and the greatest number of class sections are found in the largest community colleges. And, as was shown above, the larger schools did not appear amongst the three community colleges chosen as case studies. Thus, while there is a positive correlation between size of school and foreign language offerings, there was no evidence to support the proposition that the presence of foreign language programs and instructors, per se, has assisted in the evolution and development of the most highly developed international education programs as they are constituted today. 
Therefore, the proposition or hunch is rejected more so than it is accepted. The presence of foreign language instruction does not, in and of itself, lead to strong international education programs and activities. An argument can be made that without foreign language instruction a college community could be even further lacking in knowledge about international education than what most campuses are today.

\section{The Presence of Foreign Born Faculty}

The evidence that the presence of foreign born faculty and staff do enhance the advancement of international education and programs at the region's community colleges seems clear. While the overall percentage of foreign born faculty to the total faculty varied from institution to institution and across the study, the evidence obtained in the case studies show that their presence has been felt in the evolution and development of international education programs and activities.

Twenty percent of the Shoreline community college faculty was born in a foreign country. Tacoma and seattle Central, two of the top seven community colleges in this field, also had double digit percentages of foreign born faculty. By comparison, Edmonds and Mt. Hood had only five percent and three percent figures, respectively.

From the case studies, interestingly enough, Mt. Hood, which was close to the mean for all colleges and having the 
lowest percentage of foreign born faculty (3.31\%) among the three most highly developed campuses, had a very active foreign born instructor who helped keep international education alive and well for a long number of years: Tilly Harris of the Spanish department. Edmonds, likewise, did not have a high percentage of foreign born faculty and staff, but their very active associate dean for international student services was born in Iran and has worked diligently to keep international education programs prospering.

The proposition or hunch is accepted that the presence of foreign born faculty and staff does make a difference in the evolution and development of international education and activities. Although, in theory, a campus could, indeed, develop without the presence of foreign born individuals.

\section{Staff Experiences Abroad}

From this study, it would appear that international education programs and activities are, indeed, being decided by faculty and staff who are involved through birth, travel, and experiences abroad.

As was shown in the proposition above, foreign born faculty and staff do have a positive influence in this field. From the case studies, it showed that the more faculty and staff travelled abroad the greater the likelihood of involvement with international education and activities. All the presidents have travelled abroad extensive- 
1y. Mt. Hood Community college has received three Fulbright-Hays Summer Abroad Projects enabling more than 30 staff members to Jive and do research in a foreign country for six or more weeks at a time. Shoreline Community college has been quite active in student study abroad programs that involve faculty as lecturers and guides to the students. Edmonds Community college has been using faculty and staff teams to go to other countries and help in the recruiting of international students. Both Edmonds and Mt. Hood have been sending their full-time staff and instructors to Japan for either extended stays or short visits to their branch campuses.

All the interviewees at the three case study campuses highlighted the need for staff to gain experiences abroad as a part of the overall internationalization of their campuses. It is possible, then, to strongly accept the proposition that faculty and staff experiences abroad contributes heavily to the evolution and development of international education and activities of a community college.

\section{RECOMMENDATIONS}

The research conclusions in this study led to the following recommendations for community college leaders in both an evaluation of existing international education practices and in the design and implementation of new inter- 
national education programming.

1. Add a hiring qualification based on international educational interests irrespective of the job position. If new faculty and staff being hired are already interested in cultural diversity and international education, the implementation of new programming will be more readily acceptable by all. With the presence and availability of U.S. educated foreign born. faculty, extend employment opportunities to this group of individuals as well. Because no one can ever predict where leadership may come from on this or any other issue in the long life of a community college campus, faculty and staff who are pre-disposed to international education will break down many of the obstacles to change.

2. Appoint at least one full-time person in charge of international student services. Even for the campus that is philosophically opposed to a strong international education unit of the college, international students will be arriving, if they haven't already, as the world continues to shrink to the level of a global village. With at least one full-time person in charge of international student services, the potential for the growth and development of international education will be enhanced. Two of the three leading international education community colleges owe their posi-tion and strength to the number of international students attending their colleges. 
3. Actively recruit international students. International students bring a world of resources to the main campus that can, and do, quickly find a way into the main.stream of the life of the college. International students are usually bright, eager, respectful, hard working individuals that help create a cosmopolitan atmosphere for the campus. They also contribute heavily to the economic fortunes of the college and the surrounding community.

4. Appoint or assign at least one person to develop grants and external funding sources in the field of international education. The opportunities to advance international education with external funding are numerous and are only limited by the imagination of the campus leadership. The whole world is the hunting ground for such opportunities. The federal government, foreign governments, multinational businesses and many, many others are all looking for the right place to conduct their training needs in this area.

5. Strengthen the teaching of ESL/ENL. With more than a ten percent increase in immigration into the United States in the past ten years by non-English speaking residents, the need for ESL/ENL is well documented in practically every community college district in the United states. It seems that the rest of the world wants very much to learn English as it has become the language of internationalists and business leaders around the world. ESL/ENL instruction 
could easily become the backbone of any community college international education program now and in the future, especially so as more and more people will be looking to the United States and other English speaking countries for training.

6. Identify at least one full-time administrator to have responsibility for the coordination of the development and implementation of international education programming. Even if not assigned full-time to this position, a campus will be well served to have at least one full-time person identified as responsible for international education as the hundreds and thousands of inquiries about international education issues circulate from both internal and external constituents. This administrator should be as close to the office of the president in the table of organization as possible because so many of the external constituents will be CEOs and major government figures who will want access to the president as a sign of project importance and priority.

7. Encourage faculty and staff to travel abroad. When a college utilizes the use of sabbaticals, team recruiting efforts, study abroad programs, and faculty exchanges, a campus can translate these programs into direct participation from faculty and staff who have experienced foreign travel. The benefits will quickly move both into the classroom and into the mainstream of campus life. 
8. Encourage student travel abroad. While it is probably more difficult for community college students to finance and participate in study abroad programs, the enthusiasm of such programing can have indirect benefits by adding to the cosmopolitan atmosphere of a college campus and the surrounding community.

9. Promote foreign language teaching. The knowledge of another society's language will add to the cultural understanding of the students in the classroom. With encouragement, foreign language instructors can, and do, send the message about other cultures and other societies to the rest of the campus through student government clubs, campus wide activities, and community contacts.

10. Promote international curricula. While course offerings in international business, international studies, and non-US studies are still not very popular with community college students, their presence in the curriculum provides a strong statement to students and the community to the effect that the college participates in the entire world and not just in the United States. With time, these courses will, undoubtedly, become more popular as U.S. citizens realize the growing importance of economic, political, and social interdependence among the people of the world.

11. Incorporate an international education commitment into the college's mission statement and other public docu- 
ments. Joining the world community is an issue of leadership for our community colleges. One of the ways of exhibiting that leadership on this issue is to include statements about the college's commitment to internationalism in as many public documents as possible, but especially in the college's mission statement. Only thirteen of the thirty community colleges surveyed had a reference to internationalism or international education in their mission statements. Very few of the college catalogs received in this study devoted any space at all to their being a part of the world or had a view that extended beyond their local community college district. In the last decade of the twentieth century, can we afford as a society to be that parochial in our thinking and actions?

12. Promote participation in international education consortia and international education organizations and associations. The participation in consortia, organizations, and associations devoted to international education, of which there are many, will provide faculty and staff with the knowledge and training necessary to further develop and strengthen all aspects of international education through collaboration within networks beyond the main campus.

The twelve recommendations above have been discerned from this research. They can be used for both the evaluation and implementation of international education programs 
and activities at a community college. If followed and with time, a community college can develop and strengthen their involvement in this most exciting and dynamic enterprise. International education has the potential of literally transforming a campus culture from one with a limited view of their college and community to a broader view of the world surrounding them.

\section{SUGGESTIONS FOR FUTURE STUDY}

This study was limited to the five basic objectives detailed earlier. Further study on the value of international education to, say, the local community, the faculty and staff of a community college, or on other educational outcomes is highly desirable and goes beyond the scope and domain of this study.

The preceding conclusions and recommendations regarding the current status of international education at the public community colleges of oregon and Washington were developed from both a survey questionnaire and three case studies. The findings of this study were unique in that no previous research into oregon and Washington community college practices in this field existed. Some of the findings, however, did verify and support some of the generalizations found in the literature review. Some of the findings, likewise, contradicted some of the generalizations found in the same 
literature review. Therefore, this researcher suggests that additional research be done to further verify or contradict either the literature or the findings of this study on a regional or national basis.

A second recommendation for further research would be to isolate one or more of the ten dimensions in the taxonomy created for this broad based study and concentrate more diligently on a single element or two. A third recommendation for further research would be to replicate the survey questionnaire every two or three years in order to measure those changes occurring in this extremely dynamic field of international education.

And, lastly, this author suggests that further research be done on the international education practices of the four year colleges and universities in Oregon and Washington states. By using a similar questionnaire and case study methodology, future researchers and practitioners will be able to compare and contrast the similarities and differences between community colleges and four year college and universities in the field of international education.

The field of international education, with its many myriad dimensions, is wide open to new research. The research, like the field itself, is rich, diverse, and dynamic and will provide much enjoyment to anyone interested. 


\section{A SELECTED BIBLIOGRAPHY}

Adams, Art. "The Illinois Consortium for International Studies." In Sakamoto and Fifield, The Next Challenge: Balancing International Competition \& Cooperation. Washington, D.C.: AACJC Publications, 1987.

Adams, Hugh. "A Rationale for International Education." In King and Brueder, Advancing International Education. San Francisco: Jossey-Bass, Inc., 1979.

Albin, Frank. "U.S.-Japan Trade, A Global Perspective." In Kelleher, Our Changing World. Tacoma: Pacific Lutheran University Press, 1985.

Anderson, Charles J. International Studies for Undergraduates, 1987 operations and Opinions. Washington, D.C.: American Council on Education, 1988.

Andrews, Stanley B. The Role of American Community Colleges in International Development Activities: Expanding the Community Base. Unpublished dissertation, Southern Illinois University, 1982.

Astin, Alexander. Achieving Educational Excellence. San Francisco: Jossey-Bass, Inc., 1985.

Backman, Earl, (ed.) Approaches to International Education. American Council on Education/Macmillan Co., 1984.

Bailey, G. Elizabeth. "Pima Community College." In Backman, Approaches to International Education. New York: American Council on Education/Macmillan Co., 1984.

Bannon, Sharon and Michael Kramer. "In Someone Else's Shoes." Community and Junior College Journal, Vol. 55, Dec/Jan 1984-85, pp. 39-45.

Barber, E., P.G. Altbach, and R.G. Meyers. "Foreign Students in Comparative Perspective." Comparative Education Review, Vol. 28, May 1984, pp. 163-339.

Barrows, Thomas, John Clark, and Stephen Klein. "College Students' Knowledge and Beliefs: A Survey of Global Understanding." Change, September 1982, pp. 17-19. 
Berry, Howard A. "Rockland Community College." In Backman, Approaches to International Education. New York: American Council on Education/Macmillan Co., 1984.

Best, John W. Research in Education. Englewood cliffs: Prentice Hall, 1977.

Black, Robert and George W. Bonham. "The Council on Learning Project on Undergraduate Education: Education and the World View." The Annals of the American Academy of Political and Social Sciences, March 1979, pp. 102-113.

Blanco, Virgil H. and Rose M. Channing. "Community Resources for International Trade Education." Community and Junior College Journal, Vol. 55, Dec/Jan 1984-85, pp. 46-48.

Blankenship, Edward S. International Education in Florida Community Colleges: An Analysis. Unpublished dissertation, University of Florida, 1980.

Bogdan, Robert C. and Sari K. Biklin. Qualitative Research for Education: An Introduction to Theory and Methods. Boston: Allyn and Bacon Co., 1982.

Boyer, Ernest L. What Should Be the Role of Community Colleges in International Education? Keynote address presented at the 58th Annual Convention of the American Association of Community and Junior Colleges, Atlanta, 1980 .

Brademas, John. "The Importance of Learning About the Rest of the World." The Chronicle of Higher Education, Vol. 21,1982, p.48.

Breuder, Robert L. and Maxwell king. "The Canadian Connection." Community and Junior College Journal, Vol. 47, May 1977, pp. 28-29.

Breuder, Robert L. Roy G. Adama. "Internationalizing Cooperative Vocational Education." Community College Review, Vol. 9, Summer 1981, pp. 40-45.

Breuder, Robert L. and Maxwell King. "Formalizing the Taiwan Connection." Community and Junior College Journal, Vol. 51, Nov. 1980, pp. 28-30.

Breuder, Robert L, and Maxwell King. "A Cooperative in the World Community." Community and Junior College Journal, Vol. 49, 1979, pp. 24-27. 
Breuder, Robert L. "A Statewide Study: Identified Problems of International students Enrolled in Public community College/Junior Colleges." Unpublished paper, Florida State University, 1972, 73 pages (ED 062 977).

Bullard, Betty M. "A Promising Agenda: International Studies in Elementary and Secondary Education." The Annals of the American Academy of Political and social Science, May 1980, pp. 91-101.

Burn, Barbara B. and James A. Perkins. "International Education in a Troubled World." The Annals of the American Academy of Political and Social Science, May 1980, pp. 17-30.

Burn, Barbara B. Expanding the International Dimension of Higher Education. San Francisco: Jossey Bass, Inc., 1980 .

Burn, Barbara B. "Study Abroad and International Exchanges." The Annals of the American Academy of Political and Social Science, May 1980, pp. 129-140.

Cape, Ruth I. and Anita Colby. "Sources and Information: Internationalizing the Community College." In Greenfield, Developing International Education Programs. San Francisco: Jossey-Bass, Inc., 1990, pp. 109-118.

Carnes, James R. A Study of Successful Management Teams in oregon Public School systems. Unpublished dissertation, Portland State University, 1988.

Channing, Rose M. and Virgil Blanco. "A Transnational outlook." Community and Junior College Journal, Vol. 51, De/Jan 1980-81, pp. 6-10.

Chickering, A.W. and Associates. The Modern American College: Responding to the New Realities of Diverse Students and a changing society. San Francisco: JosseyBass, Inc., 1981.

Chisti, Salim. "Economic Costs and Benefits of Educating Foreign Students in the United States." Research in Higher Education, Vol. 21, 1984, pp. 397-414.

Christensen, A.C. and M.D. Whitaker. "A Rationale for University Involvement in the International Arena." Journal of General Education, Vol. 35, 1983, pp. 3-14. 
Chronicle of Higher Education Almanac, The. Washington, D.C.: The Chronicle of Higher Education Publishing, Inc. 1989.

Chronicle of Higher Education, The. "Triton Community College," March 29, 1989, p. A17.

Chronicle of Higher Education, The. "Foreign students in the United States," October 23, 1991, p. A1, A39, A41.

Cleveland, Harlan. "The Internationalization of Domestic Affairs." The Annals of the American Academy of Political and Social Science, March 1979, pp. 125-137.

Cohen, Arthur M. and Florence B. Brawer. The American Community College. San Francisco: Jossey-Bass, Inc., 1982 .

Cooney, D.T. The Foreign student Program in Florida Public Community colleges. Unpublished paper, Florida State University, 1974, 52 pages (ED 095 935).

Copeland, I. and I. Griggs. Going International: How to Make Friends and Deal Effectively in the Global Marketplace. New York: Random House, Inc., 1985.

Craig, B. Lee. "Variations and Themes in International Education." Educational Record, Vol. 62, Winter 1981, pp. $41-46$.

Culton, Donald R. Los Angeles Community Colleges: A Guide to the International Education Program. Unpublished paper, 1981 (ED 231 491).

Davis, Barbara Bradford. "Improving International Business Education: A Report on Curricular Innovation." In Sakamoto and Fifield, The Next Challenge: Balancing International Competition \& Cooperation. Washington, D.C., AACJC Publications, 1987.

Deegan, William L. and Dale Tillery and Associates. Renewing the American Community College. San Francisco: Jossey-Bass, Inc., 1985.

Diaz, Carlos and et al. "Improving International Relations: Is There a Role for the Community Colleges?" Community and Junior College Journal, Vol. 55, Dec/Jan 1984-85, pp. 32-37. 
Diener, Thomas and Lornie Kerr. "Institutional Responsibilities to Foreign students." In King and Breuder, Advancing International Education. San Francisco: Jossey-Bass, Inc., 1979, pp. 49-56.

Diener, Thomas. "Foreign students and US Community Colleges." Community College Review, Vol. 7, Spring 1980, pp. 58-65.

Drucker, Peter F. The New Realities: In Government and Politics, In Economics and Business, In society and World View. New York: Harper and Row Publishers, Inc. , 1989.

Dupere, M. "Global Development of the Two-Year College Concept." Higher Education, Vol. 3, 1974, pp. 315-329.

Easton, Susanna c. "The Business and International Education Program of the US Department of Education." In Sakamoto and Fifield, The Next Challenge: Balancing International Competition \& Cooperation. Washington, D.C.: AACJC Publications, 1987.

Ebersole, Bradley J. "The Faculty Expatriot: Living and Teaching Abroad." Community, Technical, and Junior College Journal, Vol. 61, August/September 1990, pp. 26-31.

Ebersole, Bradley J. "International Education: Where and How Does It Fit in Your college, Community and Junior College Journal, Vol. 59, Dec/Jan 1988-89, pp. 29-31.

Ebersole, Bradley J. Community Colleges for International Development (CCID): International Education Program Policy and Administration. Unpublished dissertation, University of Maryland, 1987.

El-Khawas, Elaine. Community College Fact Book. New York: Macmillan Publishing Co., 1988.

Edwards, Jane and Humphrey R. Tonkin. "Internationalizing the Community College: Strategies for the Classroom." In Greenfield, Developing International Education Programs. San Francisco: Jossey-Bass, Inc., 1990, pp. 17-26. 
Fersh, Seymour. "Adding an International Dimension to the Community College: Examples and Implications." In Greenfield, Developing International Education Programs. San Francisco: Jossey-Bass, Inc., 1990, pp. 6776 .

Fersh, Seymour. "The Community college and the World Community." Community College Frontiers, Vol. 9, 1982, pp. 4-10.

Fersh, Seymour. (ed.) The community college and International Education: A Report of Progress. Washington, D.C.: US Department of Education, 1981 (ED 211 153).

Fersh, Seymour. "Cultural studies: Becoming our own Teachers." In King and Breuder, Advancing International Education. San Francisco: Jossey-Bass, Inc., 1979, pp. 31-36.

Fersh, Seymour. "Worldwide Dimensions Enrich Community Based Education." Community and Junior College Journal, Vol. 49, 1979, pp. 14-19.

Fifield, Mary L., Sandra Foster, Russ Hamm, and Charlotte Lee. "Workers for the World: Occupational Programs in a Global Economy." Community, Technical, and Junior College Journal, Vol. 61, August/September 1990, pp. 15-19.

Fifield, Mary L. International Education: A Case study of Innovation in the community college. Unpublished dissertation, st. Louis University, 1988.

Ganesh, S.R. and D. Sarupria. "Explorations in Helplessness of Higher Education Institutions in the Third World." Higher Education, Vol. 12, 1983, pp. 191-204.

Gannon, Phillip J. "Future Outlook: World Class Colleges Coming." Community and Junior College Journal, Vol. 53, April 1983, p. 41.

Gleason, William and Nancy Hazelwood. "Small colleges and International Business Education: A Consortial Perspective." In Sakamoto and Fifield, The Next Challenge: Balancing International Competition \& Cooperation. Washington, D.C.: AACJC Publications, 1987.

Gleazer, Edmund J., Jr. This is the Community College. Boston: Houghton Mifflin, 1968. 
Glick, Ervie I. "An Unexplored Realm: International Education." Community College Frontiers, Vol. 7, Fall 1978, pp. 22-27.

Grant, Sidney R. "Internationalizing the College curriculum." In King and Breuder, Advancing International Education. San Francisco: Jossey-Bass, Inc., 1979, pp. 19-30.

Grapentier, Elizabeth. International Education: Survey and Assessment. Unpublished dissertation, Wayne state University, 1973.

Greene, William. "Establishing American Colleges Abroad." Community, Technical, and Junior College Journal, Vol. 61, August/September 1990, pp. 20-25.

Greene, william. "Developing American Two-Year College Programs Abroad." In Greenfield, Developing International Education Programs. San Francisco: Jossey-Bass, Inc., 1990, pp. 67-76.

Greene, william. "International Education in Florida: A Decade of Progress." In Sakamoto and Fifield, The Next Challenge: Balancing International Competition \& Cooperation. Washington, D.C: AACJC Publications, 1987.

Greene, Wiliiam. "Area 8: The International/Intercultural General Education Requirement." Community and Junior College Journal, Vol. 55, Dec/Jan 1984-85, pp. 18-23.

Greene, William. International Education Programs in Selected Florida community colleges. Unpublished dissertation, Florida Atlantic University, 1980.

Greene, William and Hugh Adams. "Consorting in the Realm of International Education -- A Statewide Approach." Community and Junior College Journal, Vol. 49, March 1979, pp. 41-43.

Greenfield, Richard K. (Ed.) Developing International Education Programs. San Francisco: Jossey-Bass, Inc., 1990 .

Groenings, Sven. "Beachheads in International Education." Educational Record. Vol. 64, Summer 1983, pp. 48-52.

Guba, E.G. and Y.S. Lincoln. Effective Evaluation. San Francisco: Jossey-Bass, Inc., 1981. 
Gwynne, Margaret A. The Effects of Study Abroad on Community college students. Unpublished dissertation, Columbia University Teachers College, 1981.

Hanna, Helen J. A Case Study of Instructional Improvement Through Peer Observation in a Suburban High School. Unpublished dissertation, Portland State University, 1988.

Harari, Maurice. Internationalizing the Curriculum and the Campus: Guidelines for AASCU Institutions. Washington, D.C.: American Association of State Colleges and Universities, 1981.

Harrington, Fred H. and Shirley clarkson. "International Linkages: The Community college." In King and Breuder, Advancing International Education. San Francisco: Jossey-Bass, Inc., 1979, pp. 101-108.

Harris, Mathilda. "Higher Education, Business, and Government: A United Effort to Develop Oregon's International Business." In Sakamoto and Fifield, The Next Challenge: Balancing International competition \& cooperation. Washington, D.C.: AACJC Publications, 1987.

Harrison, Carole B. A Systematic Planning Model for Institutional Curriculum Development: Testing Its Effectiveness in International/Intercultural Education at a Selected community college. Unpublished dissertation, Florida State University, 1980.

Hart, Roy H. Problems of International students Enrolled in Texas Public community colleges as Perceived by International student Advisors. Unpublished dissertation, East Texas State University, 1974.

Hayden, Rose. "laking the Word to Washington." In king and Breuder, Advancing International Education. San Francisco: Jossey-Bass, Inc., 1979, pp. 79-88.

Hess, Gerhard. Freshman and Sophmores Abroad: Community Colleges and Overseas Academic Programs. New York: Teachers College press, 1982 .

Hess, Gerhard. Overseas Academic Programming on the Community college Level -- The Rockland Model. Unpublished dissertation, Columbia University Teachers college, 1979 . 
Hill, Andrew. "Sources and Information on the community College in a Global context." In King and Breuder, Advancing International Education. San Francisco: Jossey-Bass, Inc., 1979, pp. 117-122.

Hochhauser, Gail A. "Developing the Campus-Community Iink in International Education." In Greenfield, Developing International Education Programs. San Francisco: Jossey-Bass, Inc., 1990, pp. 99-108.

Icochea, Lynda. "Community Resources for International Business Programs." In Sakamoto and Fifield, The Next Challenge: Balancing International competition \& Cooperation. Washington, D.C.: AACJC Publications, 1987.

Icochea, Lynda. "Bergen Community College." In Backman, Approaches to International Education. New York: American Council on Education/Macmillan, 1984.

Jacobsen, Rebecca. "Nigerian Challenge." Community and Junior College Journal, Vol. 49, March 1979, pp. 32-34.

Jenkins, Hugh. Educating students from other Nations. San Francisco: Jossey-Bass, Inc., 1983.

Johnson, Lamar B. "Is the Junior College Idea Useful for other Countries?" Community and Junior College Journal, Vol. 32, 1961, pp. 3-8.

Jones, Christene $\mathrm{K}$. Staff Development and the Process of Teacher Change: A Case study. Unpublished dissertation, Portland State University, 1989.

Jones, Enid and James L. Wattenbarger. "A Plan for Community Colleges in Jamaica." Community, Technical, and Junior College Journal, Vol. 61, August/September 1990, pp. 31-36.

Justiz, Manual J. "Easing Tensions on the Border." Community and Junior College Journal, Vol. 51, Sept. 1980, pp. 12-16.

Kelleher, Ann. (ed.) Our Changing World. Tacoma: Pacific Lutheran University Press, 1985.

Kerr, Clark. "Education for Global Perspectives." The Annals of the American Academy of Political and Social Science, March 1979, pp. 109-116. 
Keyser, John. "Planetary Birth Experience." Community, Technical, and Junior College Journal, Vol. 61, August/September 1990, p. 4.

Keyser, John. "Decision Makers: Neil Goldschmidt, Governor of Oregon." Community and Junior College Journal, Vol. 59, Dec/Jan 1988-89, pp. 10-12.

King, Maxwell. "The Community College's International vision." Community, Technical, and Junior College Journal, vol. 61, August/September 1990, pp. 37-40.

King, Maxwell. "Foreign Technical-Assistance Programs." In Greenfield, Developing International Education Programs. San Francisco: Jossey-Bass, Inc., 1990, pp. 7786 .

King, Maxwell C. and Seymour Fersh, "International Education: Its Future Is Now," The community and Junior College Journal, Vol. 59, Dec/Jan 1988-89, pp. 28-29.

King, Maxwell c. and Seymour Fersh. "International Education and the US Community college: From optional to Integral." Junior College Resource Review. Washington, D.C.: NIE, spring 1983.

King, Maxwell C. and Seymour Fersh. "Implementing the International Dimension: A Welcome Imperative." The Community College Humanities Review. Philadelphia: Community College Humanities Association, Vol. 8, 1987.

King, Maxwell C. and Robert L. Breuder. (ed.) Advancing International Education. San Francisco: Jossey-Bass, Inc., 1979 .

Kintzer, Frederick. "World Adaptations of the Community College Concept." In King and Breuder, Advancing International Education. San Francisco: Jossey-Bass, Inc., 1979, pp. 65-78.

Klein, Frank. "The Partnership Between US Higher Education and Developing Countries' Needs: Fact or Fiction?" Journal of Studies in Technical Careers, Vol. 7, winter 1985, pp. 42-48.

Lambert, Richard D. Beyond Growth: The Next Stage in Language and Area studies. Washington, D.C.: Association of American Universities, 1984. 
Lambert, Jonathon. "Study Abroad and the Community College." NAFSA Newsletter, Vol. 35, Dec/Jan 1984-85, p. 75 .

Lambert, Richard D. "Durable Academic Linkages overseas: A National Agenda." The Annals of the American Academy of Political and Social Science, May 1980, pp. 140-153.

Leinwald, George. The Challenge of Internationalizing the Curriculum and the Campus. Washington, D.C.: American Association of State Colleges and Universities, 1983.

Magrath, Peter C. "International Education and Language Studies: A Question and a Proposal." Change, May 1982, pp. 8-9.

Mahoney, James R. and Clyde Sakamoto. (eds.) International Trade Education: Issues and Programs. Washington, D.C.: AACJC Publications, 1985.

Marler, Lewis c. "Impact of International Trade on the washington state Economy." In Kelleher, our Changing World. Tacoma: Pacific Lutheran University Press, 1985 .

Martorana, S.V and William G. Shannon. "International Education, the college, and the Community: A Framework for Action." In King and Breuder, Advancing International Education. San Francisco: Jossey-Bass, Inc., 1979, pp. 11-18.

Maurer, Ernest W. "Planning and Implementing an International Technical Workshop." In Sakamoto and Fifield, The Next Challenge: Balancing International Competition $\&$ Cooperation. Washington, D.C.: AACJC Publications, 1987 .

Mayes, Jim L. An Assessment of the Attitudes of Full-time Administrators and Faculty Toward International Education in Two Florida Community Colleges. Unpublished dissertation, University of Florida, 1981.

McArthur-Bielinski, seonaid. International Education in Five Community Colleges: Individual, Environmental, and organizational Impacts on Innovation Diffusion. Unpublished dissertation, University of Southern california, 1983. 
McLean, John J. "Consortial Approaches to International Education." In Greenfield, Developing International Education Programs. San Francisco: Jossey-Bass, Inc., 1990, pp. 47-56.

Merriam, Sharan B. Case Study Research in Education. San Francisco: Jossey-Bass, Inc., 1988.

Mundt, John c. "Community College state Boards and International Education." In King and Breuder, Advancing International Education. San Francisco: Jossey-Bass, Inc., 1979, pp. 89-100.

Naisbitt, John. Megatrends. New York: Warner Books, Inc., 1983.

National Association of Foreign Student Affairs. Handbook for Community organizations Working with Foreign students: Developing, Maintaining, Revitalizing Programs. Washington, D.C.: National Association of Foreign Student Affairs, 1986.

National Association of Foreign Student Affairs. Standards and Responsibilities in International Education Interchange. Washington, D.C.: National Association of Foreign student Affairs, 1981.

National Commission on Excellence in Education. A Nation at Risk. Washington, D.C.: US Government Printing office, 1983 .

Newell, Barbara W. "Education with a World Perspective -A Necessity for America's Political and Economic Defense." The Annals of American Academy of Political and Social Science, May 1987, pp. 134-139.

Nieto, Jesus G. A Descriptive Analysis of an International and Intercultural Approach in a Community College Setting. Unpublished dissertation, University of Southern California, 1975.

Norton, Sherry M. "Building the International Dimension of Your Campus: The USIA International Visitor Program and other Resources." In Sakamoto and Fifield, The Next Challenge: Balancing International competition \&Cooperation. Washington, D.C.: AACJC Publications, 1987.

O'Malley, Elizabeth M. Global Awareness of Administrators in Higher Education in the State of oregon. Unpublished dissertation, Portland state University, 1983. 
o'Sullivan, Wayne. "The Community College: An International Institution." In Sakamoto and Fifield, The Next Challenge: Balancing International competition \& Cooperation. Washington, D.C.: AACJC Publications, 1987.

Oregorian. "Sister Cities," July 18, 1989, p. D1.

Oregonian. "MHCC in Japan," August 3, 1989, p. C1.

Parnell, Dale. The Neglected Majority. Washington, D.C.: AACJC Publications, 1985.

Parnell, Dale. Building Communities: A Vision for a New Century. Washington, D.C.: AACJC Publications, 1988.

Peck, Shirley S. "Global Issues in Career and Technical Fields: Internationalizing the Community College Curriculum." Community/Junior College Quarterly, Vol. 15, No. 2, 1991, pp. 165-174.

Perkins, James A. President's Commission on Foreign Lanquage and International studies. Washington, D.C.: US Government Printing Office, 1979.

Ponitz, David. "A Hard Look at International Education." Community and Junior College Journal, Vol. 59, Dec/Jan 1988-89, p. 8 .

Rhinesmith, Stephen H. "Americans in the Global Learning Process." The Annals of the American Academy of Political and Social Science, March 1979, pp. 98-108.

Richardson, John., Jr. "Institutional Innovation: Organizing for Better International Relationships." The Annals of the American Academy of Political and Social Science, March 1979, pp. 117-124.

Rinehart, Richard I. "A National Symbiosis: Community Colleges and the Peace Corps." Community and Junior College Journal, Vol. 55, Dec/Jan 1984-85, pp. 24-29.

Robertson, Piedad F. and John H. Rogers. "Teaching English as a Second Language." In King and Breuder, Advancing International Education. San Francisco: Jossey-Bass, Inc., 1979, pp. 57-64. 
Robinson, Brenda S. "Expanding the Sister City Concept: Boston/Strasbourg student Exchange." In Sakamoto and Fifield, The Next Challenge: Balancing International Competition \& Cooperation. Washington, D.C.: AACJC Publications, 1987.

Robinson, Brenda S. "Facilitating Faculty Exchange." In Greenfield, Developing International Education Programs. San Francisco: Jossey-Bass, Inc., 1990, pp. 3746.

Rogers, Kenneth. "Foreign Students: Economic Benefit or Liability?" College Board Review, Vol. 133, Fall 1984, pp. 20-25.

Russell, Mary. "Statistics on Washington state Community College students," personal communication, 1989.

Sakamoto, Clyde and Mary Fifield. (eds.) The Next Challenge: Balancing International Competition \& Cooperation. Washington, D.C.: AACJC Publications, 1987.

Scanlon, David G. "Lessons from the Past in Developing International Education in Community colleges." In Greenfield, Developing International Education Programs. San Francisco: Jossey-Bass, Inc., 1990, pp. 512 .

Schultz, Raymond E. "A Focus for Community College Development in Europe." In King and Breuder, Advancing International Education. San Francisco: Jossey-Bass, Inc, 1979, pp. 37-48.

Seppen, Rose. "Statistics on oregon state Community College students," personal communication, 1989.

Schultz, Raymond E. "Two-Year Colleges Move Toward Global orientation." Community College Review, Vol. 5, Fall 1977, pp. 15-28.

Shannon, William G. A Survey of International/Intercultural Education in Two-Year Colleges - 1976. Washington, D.C.: US Department of Health, Education and Welfare, 1979 (ED 164 034).

Simon, Paul. "Is America Tongue-Tied?" Academe, Vol. 69, March/April 1983, pp. 9-12. 
Spofford, William K. "The Effective Development of Nontraditional study-Abroad Programs." In Greenfield, Developing International Education Programs. San Francisco: Jossey-Bass, Inc., 1990, pp. 27-36.

Starr, S. Frederick. (Chair.) The President's commission on Foreign Language and International studies: Reports Its Recommendations and Analysis. Washington, D.C.: US Government Printing office, 1979.

Sterns, Maurice A. "Educational Exchange in Latin America." The Annals of the American Academy of Political and Social Science, May 1987, pp. 104-117.

Tahijian-Brown, James E. A Study of Student Services for International students in the Virginia community college system. Unpublished dissertation, University of Virginia, 1978.

Tillman, Martin J. "Effective Support-Services for International students." In Greenfield, Developing International Education Programs. San Francisco: Jossey-Bass, Inc., 1990, pp. 87-98.

Vassiliou, Elena. "Parameters of International studies." Community and Junior College Journal, Vol. 55, Dec/Jan 1984-85, pp. 14-17.

Weisberg, Herbert F., Jon A. Krosnick, and Bruce D. Bowen. An Introduction to Survey Research and Data Analysis. Boston: Scott, Foresman and Company, 1989.

Willard, Wayne E. Identified Problems of International Students Enrolled in Public Junior Colleges in Illinois. Unpublished dissertation, Florida State University, 1973.

Wood, Santiago. International Business Education Programs in the California Community colleges. Unpublished dissertation, University of San Francisco, 1986.

Woods, Randall B. "Fulbright Internationalism." The Annals of the American Academy of Political and Social Science, May 1987, pp. 22-35.

Wygal, Benjamin. "Weathering the Heavy Seas of International Education." In King and Breuder, Advancing International Education. San Francisco: Jossey-Bass, Inc., 1979, pp. 109-116. 
Yarrington, Roger. Internationalizing Community colleges. Washington, D.C.: AACJC Publications, 1978.

Yarrington, Roger. International Development of the Junior College Idea. Washington, D.C.: AACJC Publications, 1970 .

Yin, Robert $\mathrm{K}$. Case Study Research: Design and Methods. Newbury Park: Age Publications, Inc., 1989. 
APPENDIX A

LETTER 
3222 NE 29th Street

Gresham, OR 97030

July 20,1990

\section{Dear President:}

International education seems to be on nearly everyone's mind these days. At the recently concluded AACJC convention in Seattle, where the theme was, "Think Globally, Act Locally," speaker after speaker rose to the occasion and lauded the virtues of becoming involved in the global community in which we live.

Just how active are community colleges in this arena? Our research base is fairly small, and not very many actually know just how involved our community colleges are in this exciting and dynamic enterprise. In fact, very few even have a comprehensive definition for us to work from as we seek out more information.

As a long-time student of the community college and as a practitioner for the past twenty years, I have a strong professional interest in the subject of international education. As a result, I have chosen as a dissertation topic, International Education in the Public Community Colleges of Oregon and Washington, in order to gain greater insights into what we in the pacific northwest region are doing in this field.

To complete my work and to add to our understanding, I need your assistance in filling out the enclosed questionnaire. From pilot testing with two community college presidents, one in California and one in New York, it will take you only about fifteen minutes to complete and return. I realize how very busy you are, especially at this time of year, but I believe the findings will be of help in the understanding of what all Oregon and Washington community colleges are doing in the field of international education.

I thank you in advance of your participation in this research, and look forward to receiving your completed questionnaire. I have enclosed a stamped return envelope for your use.

Again, thank you very much.

Most sincerely,

Stephan E. Cragg 
APPENDIX B

THE PUBLIC COMMUNITY COLLEGES

OF OREGON AND WASHINGTON STATES 
RESPONDED: PARTIAL RESPONSE:

\begin{tabular}{|c|c|c|}
\hline \multicolumn{3}{|l|}{ BELLEVUE CC } \\
\hline BIG BEND CC & $\mathrm{XX}$ & \\
\hline BLUE MOUNTAIN CC & $\mathrm{XX}$ & \\
\hline CENTRAL OREGON CC & $\mathrm{XX}$ & \\
\hline \multicolumn{3}{|l|}{ CENTRALIA CC } \\
\hline CHEMEKETA CC & $\mathrm{XX}$ & \\
\hline CLACKAMAS CC & $\mathrm{XX}$ & \\
\hline CLARK CC & $\mathrm{XX}$ & \\
\hline CLATSOP CC & $\mathrm{XX}$ & \\
\hline COLUMBIA BASIN CC & $\mathrm{XX}$ & \\
\hline \multicolumn{3}{|l|}{ COLUMBIA GORGE CC } \\
\hline EDMONDS CC & $\mathrm{XX}$ & \\
\hline EVERETT CC & $\mathrm{XX}$ & \\
\hline \multicolumn{3}{|l|}{ GRAYS HARBOR CC } \\
\hline \multicolumn{3}{|l|}{ GREEN RIVER CC } \\
\hline HIGHLINE CC & $\mathrm{XX}$ & \\
\hline LANE CC & $\mathrm{XX}$ & \\
\hline LINN-BENTON CC & $\mathrm{XX}$ & \\
\hline LOWER COLUMBIA CC & $\mathrm{XX}$ & \\
\hline MT. HOOD CC & $\mathrm{XX}$ & \\
\hline OLYMPIC CC & & $\mathrm{XX}$ \\
\hline OREGON COAST CC & $\mathrm{XX}$ & \\
\hline \multicolumn{3}{|l|}{ PENINSULA CC } \\
\hline PIERCE COLLEGE & $\mathrm{XX}$ & \\
\hline PORTLAND CC & $\mathrm{XX}$ & \\
\hline ROGUE CC & $\mathrm{XX}$ & \\
\hline SEATTLE CENTRAL CC & $\mathrm{XX}$ & \\
\hline SEATTLE NORTH CC & $\mathrm{XX}$ & \\
\hline \multicolumn{3}{|l|}{ SEATTLE SOUTH CC } \\
\hline SHORELINE CC & $\mathrm{XX}$ & \\
\hline SKAGIT VALLEY CC & $\mathrm{XX}$ & \\
\hline SOUTH PUGET SOUND CC & $\mathrm{XX}$ & \\
\hline \multicolumn{3}{|l|}{ SOUTHWESTERN OREGON CC } \\
\hline SPOKANE FALLS CC & $\mathrm{XX}$ & \\
\hline SPOKANE CC & $\mathrm{XX}$ & \\
\hline TACOMA CC & $\mathrm{XX}$ & \\
\hline \multicolumn{3}{|l|}{ TILLAMOOK BAY CC } \\
\hline \multicolumn{3}{|l|}{ TREASURE VALLY CC } \\
\hline \multicolumn{3}{|l|}{ UMPQUA CC } \\
\hline \multicolumn{3}{|l|}{ WALLA WALLA CC } \\
\hline WENATCHEE VALLEY CC & $\mathrm{XX}$ & \\
\hline WHATCOM CC & $\mathrm{XX}$ & \\
\hline YAKIMA VALLEY CC & $\mathrm{XX}$ & \\
\hline TOTAIS: & 30 & 3 \\
\hline
\end{tabular}


APPENDIX

SURVEY QUESTIONNAIRE INSTRUMENT 


\section{INTERNATIONAL EDUCATION \\ IN THAE PUBLIC COMAUNTTY COLLEGES OF \\ OREGON AND WASTMNGTON \\ QUESTIONNATRE}

1. Nank of College:

2. Your Name and Tille:

3. Teleptone Number:

4. No. Full-Time Equivalent Studeats: 5. No. International Scudeats on Visas:

6. No. Full-Time Equivalear Faculty: 7. No. Part-ine Faculty:

8. Estinared no. Full-Time Faculty liom Outside of the Unilod States:

9. No. of Years your College has been involved with International Education Programs:

10. Why did your College get involved with Interzational Education?

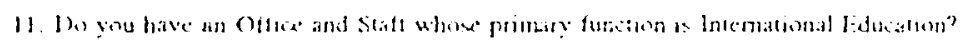

in Ye... Neminer of Stats.

12. Do you have an Admaistrator asigned to International Educitans?

No: les: Percentuge of Tiux:

13. Do you have International Student Advisor?

iv: Yas: Percentoge of Time:

14. Do you have faculy assizncd to leach Intemational Educution/Studes?
$\therefore$
lic:

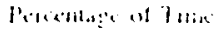

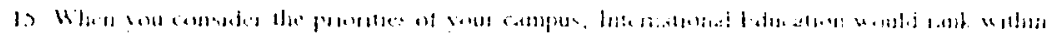
Vint Hishen

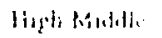
Muld
Lencas Mask.
lane: :

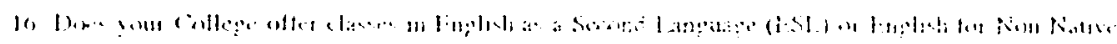
(1)....... (1) $(1)$

$$
\therefore \quad \therefore \quad \quad \therefore \quad \quad 1 \because 1 \quad \cdots \quad \therefore
$$


17. How many studeals were enrollod in ESL and ENL during the 1989-90 school year?

ESL Number:

ENL Number:

18. Does your College offer Foreigu Language classes in (chock wose that apply):

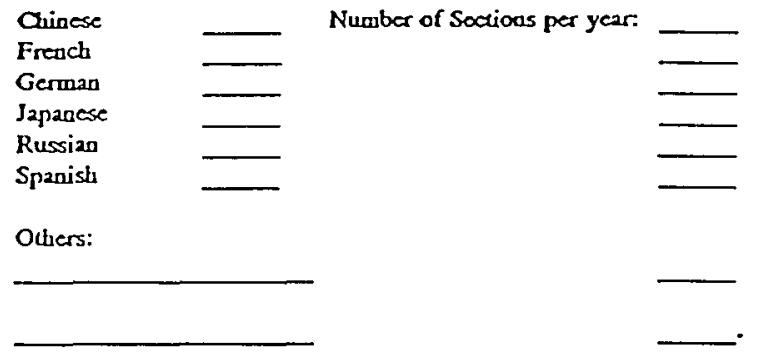

19. Does your College's Mission Statemeat include a Refereace to International Education?

Yes: . No: (Please include a copy of the statearent if not in your Catalogue.)

20. Does your College offer Student Study Abroad Programs?

Yes: - No:

21. Estimatod number of your College sudeats who sudied abroad from 1987-88 to 1989-90:

Number:

22. Where bave your students studied during 1989-90?

Country:

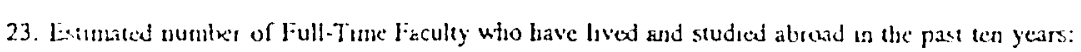

Number:

24. Estimated number of Full-Time Faculity utio have had a faculty exchange with a member of a forcign college or university in the past ten years:

Number:

25. Estmated number of Full-Time Faculty who bave travelled ahroad on then cun in the past en resir

Nuntrit: .............

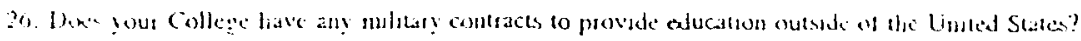

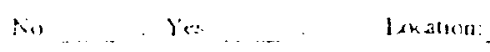


27. Does your College operate a Forcign Branch Campus?
No: Yes:
Location:
Location:

28. Is your College aclively considering opening a Foreiga Branch Cempus?

No: Yes:

Location:

29. Does your College actively rocruir Internatioaal Sudeats?

No: Yes:

30. Has your College implemented a program generically bown as "Internationalizing the Curriculurn"?

No: - Yes: Date began:

31. Does your College offer classes designated as:

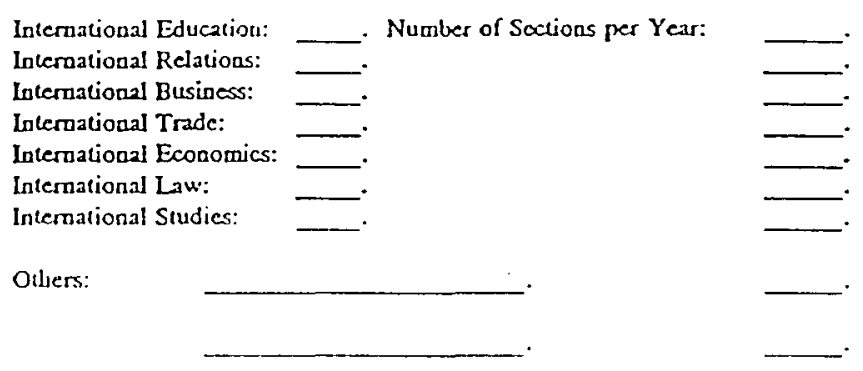

32. Dows your Collepe offer classes on the Culture. Politics, History, and/or Fconomics of other niturn?

They are:

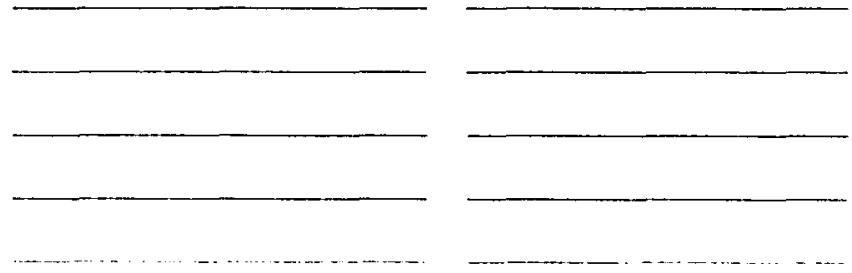

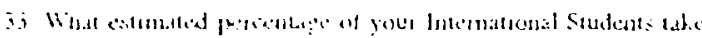

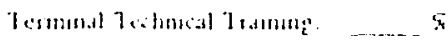

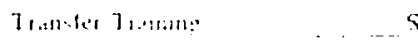

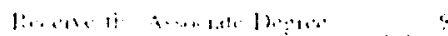


34. Does your College participate in eny Consortia for Sudeat Surdy Abroad Programs?

Countries:

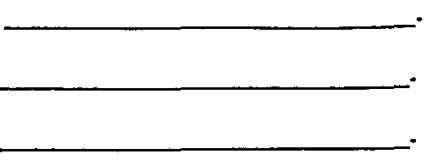

35. Please list any "Sister College" Relationdips:

College/Country:

36. Please list any Country that has askod for your essistanoc in developing a two-year community college:

Country:

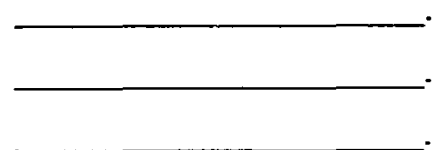

37. Please list any Intemational Education Consortia that you belong to:

Consortium/Purpose:

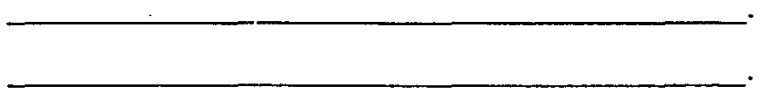

38. Please list any External/Grant Funding for International Education:

Source/Program: . Amoun:

39. Will your Collę̧c have more or less Institutional Funding for International Education in the next Budge?
Nore:
Less:
The Same:

41. In the next five years, do you expert your College to twe more or less involved in Interiational Educution?

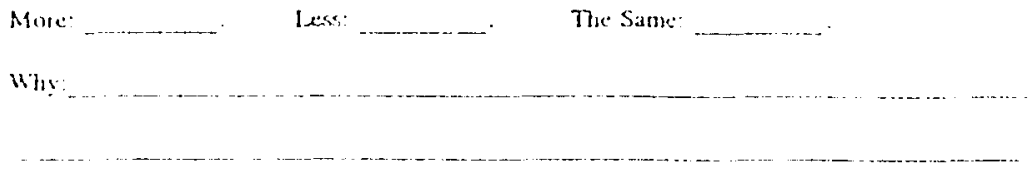


42. In the next five years, how do you think your College will be more involved:

If possible, please send me a copy of your most recent catalogue and any supporting materials on international education that you believe would assist me in this study.

Please return the completed survey to:

Stephan E. Cragg

3222 NE 29th Street

Gresham, OR 97030

Thank you very much for taking the time and effort to complete this survey! 
APPENDIX D

SURVEY RESULTS 
QUESTION \#1 NAME OF CC: $\begin{array}{ll} & \# 3 \\ \text { STATE } & \text { RESPONDENT }\end{array}$

\#4

STUDEN

FTE'S

\section{\#6 \\ FACULTY $P / T$ \\ FTE'S FAC.}

\begin{tabular}{lllrrr} 
EDMONDS CC & WA & PRESIDENT & 4,500 & 100 & \multicolumn{1}{c}{300} \\
SHORELINE CC & WA & IE COORD & 4,400 & 150 & 160 \\
MT. HOOD CC & OR & ASST PRES & 6,100 & 181 & 330 \\
TACOMA CC & WA & ESL DIR. & 3,250 & 90 & 160 \\
SPOKANE FALLS CC & WA & IE DIRECTOR & 5,823 & 158 & 716 \\
PORTLAND CC & OR & PRESIDENT & 13,929 & 372 & 995 \\
SKAGIT VALLEY CC & WA & ASST PRES & 2,600 & 110 & 200 \\
SEATTLE NORTH CC & WA & DEAN INST & 3,477 & 160 & 200 \\
LANE CC & OR & ASST VP & 8,200 & 280 & 450 \\
EVERETT CC & WA & VICE PRES & 3,600 & 180 & 120 \\
CLACKAMAS CC & OR & ASST DEAN & 4,364 & 150 & 411 \\
YAKIMA VALLEY CC & WA & PRESIDENT & 2,900 & 105 & 250 \\
SEATTLE CENTRAL CC & WA & ASSOC DEAN & 5,105 & 123 & 240 \\
HIGHLINE CC & WA & REGISTRAR & 4,613 & 115 & 186 \\
ROGUE CC & OR & DEPT CHAIR & 1,400 & 60 & 200 \\
CLARK CC & WA & IE DIRECTOR & 4,500 & 133 & 297 \\
PIERCE COLLEGE & WA & IE DIRECTOR & 4,000 & 90 & 325 \\
LINN-BENTON CC & WA & IE DIRECTOR & 4,500 & 130 & 200 \\
BIG BEND CC & WA & VICE PRES & 1,183 & 46 & 60 \\
CHEMEKETA CC & OR & DEPT CHAIR & 7,600 & 220 & 500 \\
CENTRAL OREGON CC & OR & VICE PRES & 2,000 & 110 & 100 \\
WHATCOM CC & WA & PRESIDENT & 1,400 & 42 & 60 \\
SO.PUGET SOUND CC & WA & PRESIDENT & 2,000 & 65 & 135 \\
LOWER COLUMBIA CC & WA & PRESIDENT & 2,109 & 105 & 40 \\
WENATCHEE VALLEY CC WA & ASSOC DEAN & 1,813 & 61 & 110 \\
SPOKANE CC & WA & IE DIRECTOR & 5,397 & 219 & 303 \\
COLUMBIA BASIN CC & WA & PRESIDENT & 3,493 & 98 & 215 \\
CLATSOP CC & OR & DEAN INST & 925 & 35 & 30 \\
OREGON COAST CC & OR & ASST VP & 100 & 2 & 50 \\
BLUE MOUNTAIN CC & OR & PRESIDENT & 1,650 & 73 & 220
\end{tabular}


NAME OF CC:

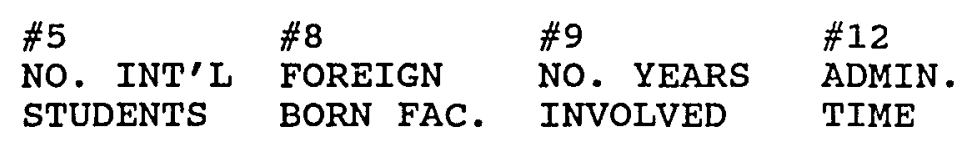

$\begin{array}{lrrrr}\text { EDMONDS CC } & 450 & 5 & 12 & 2.00 \\ \text { SHORELINE CC } & 290 & 30 & 20 & 0.20 \\ \text { MT. HOOD CC } & 53 & 6 & 16 & 2.20 \\ \text { TACOMA CC } & 124 & 10 & 23 & 0.50 \\ \text { SPOKANE FALLS CC } & 62 & 2 & 6 & 0.13 \\ \text { PORTLAND CC } & 128 & 15 & 12 & 0.13 \\ \text { SKAGIT VALLEY CC } & 55 & 8 & 25 & 0.05 \\ \text { SEATTLE NORTH CC } & 100 & 4 & 10 & 0.25 \\ \text { LANE CC CC } & 172 & 0 & 10 & 0.00 \\ \text { EVERETT CC } & 50 & 5 & 15 & 0.13 \\ \text { CLACKAMAS CC } & 17 & 6 & 25 & 0.05 \\ \text { YAKIMA VALLEY CC } & 100 & 10 & 25 & 0.00 \\ \text { SEATTLE CENTRAL CC } & 120 & 23 & 1 & 0.00 \\ \text { HIGHLINE CC } & 88 & 5 & 15 & 0.00 \\ \text { ROGUE CC } & 12 & 3 & 10 & 0.05 \\ \text { CLARK CC } & 100 & 5 & 10 & 0.40 \\ \text { PIERCE COLLEGE } & 30 & 5 & 15 & 0.50 \\ \text { LINN-BENTON CC } & 95 & 3 & 13 & 0.25 \\ \text { BIG BEND CC } & 188 & 1 & 25 & 0.05 \\ \text { CHEMEKETA CC } & 125 & 5 & 5 & 0.05 \\ \text { CENTRAL OREGON CC } & 17 & 2 & 10 & 0.00 \\ \text { WHATCOM CC } & 25 & 2 & 2 & 0.25 \\ \text { SO.PUGET SOUND CC } & 13 & 3 & 3 & 0.15 \\ \text { LOWER COLUMBIA CC } & 10 & 0 & 15 & 0.25 \\ \text { WENATCHEE VALLEY CC } & 0 & 2 & 2 & 0.05 \\ \text { SPOKANE CC } & 44 & 2 & 3 & 0.10 \\ \text { COLUMBIA BASIN CC } & 10 & 1 & 0 & 0.00 \\ \text { CLATSOP CC } & 1 & 0 & 0 & 0.00 \\ \text { OREGON COAST CC } & 0 & 0 & 0 & 0.00 \\ \text { BLUE MOUNTAIN CC } & 1 & 1 & 0 & 0.00\end{array}$




\begin{tabular}{|c|c|c|c|c|}
\hline NAME OF CC: & $\begin{array}{l}\# 11 \\
\text { NON-ADM. } \\
\text { TIME }\end{array}$ & $\begin{array}{l}\# 13 \\
\text { ADVISOR } \\
\text { TIME }\end{array}$ & $\begin{array}{l}\# 14 \\
\text { I.E. FAC. } \\
\text { TIME }\end{array}$ & $\begin{array}{l}\text { \#15 } \\
\text { INSTIT. } \\
\text { PRIORITY }\end{array}$ \\
\hline EDMONDS CC & 9.00 & 4.00 & 3.00 & HI MID \\
\hline SHORELINE CC & 3.00 & 1.00 & 1.67 & MIDDLE \\
\hline MT. HOOD CC & 2.50 & 1.10 & 1.00 & MIDDLE \\
\hline TACOMA CC & 2.00 & 1.00 & 1.00 & HI MID \\
\hline SPOKANE FALLS CC & 2.00 & 1.00 & 5.00 & HI MID \\
\hline PORTLAND CC & 0.00 & 1.00 & 3.30 & LO MID \\
\hline SKAGIT VALLEY CC & 1.50 & 0.50 & 1.25 & HI MID \\
\hline SEATTLE NORTH CC & 0.00 & 1.00 & 1.00 & MIDDLE \\
\hline LANE CC & 0.00 & 0.50 & 0.00 & HI MID \\
\hline EVERETT CC & 4.00 & 1.50 & 1.50 & HI MID \\
\hline CLACKAMAS CC & 2.00 & 0.25 & 5.00 & MIDDLE \\
\hline YAKIMA VALLEY CC & 2.00 & 1.00 & 1.50 & MIDDLE \\
\hline SEATTLE CENTRAL CC & 0.00 & 0.00 & 0.00 & MIDDLE \\
\hline HIGHLINE CC & 0.00 & 0.10 & 0.00 & HI MID \\
\hline ROGUE CC & 0.00 & 0.10 & 0.75 & MIDDLE \\
\hline CLARK CC & 2.00 & 0.50 & 0.00 & MIDDLE \\
\hline PIERCE COLLEGE & 1.00 & 0.50 & 1.67 & HI MID \\
\hline LINN-BENTON CC & 0.00 & 0.00 & 0.00 & MIDDLE \\
\hline BIG BEND CC & 0.00 & 0.10 & 0.00 & MIDDLE \\
\hline CHEMEKETA CC & 0.00 & 0.20 & 0.00 & MIDDLE \\
\hline CENTRAL OREGON CC & 0.00 & 0.05 & 0.25 & MIDDLE \\
\hline WHATCOM CC & 1.00 & 0.50 & 3.75 & MIDDLE \\
\hline SO.PUGET SOUND CC & 1.25 & 1.00 & 0.00 & MIDDLE \\
\hline LOWER COLUMBIA CC & 0.00 & 0.10 & 0.50 & LO MID \\
\hline WENATCHEE VALLEY CC & 0.00 & 0.00 & 0.00 & LO MID \\
\hline SPOKANE CC & 2.00 & 0.20 & 0.00 & MIDDLE \\
\hline COLUMBIA BASIN CC & 0.00 & 0.00 & 0.00 & LO MID \\
\hline CLATSOP CC & 0.00 & 0.20 & 0.00 & LOWEST \\
\hline OREGON COAST CC & 0.00 & 0.00 & 0.00 & LOWEST \\
\hline BLUE MOUNTAIN CC. & 0.00 & 0.00 & 0.00 & LO MID \\
\hline
\end{tabular}




\begin{tabular}{|c|c|c|c|c|}
\hline NAME OF CC: & $\begin{array}{l}\# 16 \\
\text { ESL } \\
\text { PROGRAM }\end{array}$ & $\begin{array}{l}\# 16 \\
\text { ENL } \\
\text { PROGRAM }\end{array}$ & $\begin{array}{l}\# 17 \\
\text { ESL/ENL } \\
\text { STUDENTS }\end{array}$ & $\begin{array}{l}\text { \#19 } \\
\text { MISSION }\end{array}$ \\
\hline EDMONDS CC & YES & YES & 1800 & YES \\
\hline SHORELINE CC & YES & No & 325 & YES \\
\hline MT. HOOD CC & YES & YES & 1000 & YES \\
\hline TACOMA CC & YES & No & 250 & No \\
\hline SPOKANE FALLS CC & YES & YES & 650 & YES \\
\hline PORTLAND CC & YES & YES & 475 & YES \\
\hline SKAGIT VALLEY CC & YES & YES & 200 & NO \\
\hline SEATTLE NORTH CC & YES & YES & 1418 & No \\
\hline LLANE CC & YES & NO & 145 & YES \\
\hline EVERETT CC & YES & YES & 0 & YES \\
\hline CLACKAMAS CC & YES & No & 400 & No \\
\hline YAKIMA VALLEY CC & YES & No & 70 & No \\
\hline SEATTLE CENTRAI CC & YES & YES & 1850 & YES \\
\hline HIGHLINE CC & YES & NO & 65 & YES \\
\hline ROGUE CC & YES & YES & 50 & YES \\
\hline CLARK CC & YES & YES & 648 & NO \\
\hline PIERCE COLLEGE & YES & YES & 200 & NO \\
\hline LINN-BENTON CC & YES & YES & 400 & NO \\
\hline BIG BEND CC & YES & No & 30 & YES \\
\hline CHEMEKETA CC & YES & YES & 0 & YES \\
\hline CENTRAL OREGON CC & YES & YES & 420 & YES \\
\hline WHATCOM CC & YES & NO & 150 & No \\
\hline SO.PUGET SOUND CC & YES & No & 203 & No \\
\hline LOWER COLUMBIA CC & YES & No & 200 & NO \\
\hline WENATCHEE VALLEY CC & YES & No & 480 & No \\
\hline SPOKANE CC & NO & NO & 0 & No \\
\hline COLUMBIA BASIN CC & YES & NO & 525 & NO \\
\hline CLATSOP CC & YES & NO & 102 & No \\
\hline OREGON COAST CC & YES & No & 153 & NO \\
\hline BLUE MOUNTAIN CC & YES & No & 221 & NO \\
\hline
\end{tabular}




\begin{tabular}{|c|c|c|c|c|}
\hline NAME OF CC: & $\begin{array}{l}\# 18 \mathrm{a} \\
\text { FOREIGN } \\
\text { LAANGUAGES }\end{array}$ & $\begin{array}{l}\# 18 \mathrm{~b} \\
\text { DIFFERENT } \\
\text { LANGUAGES }\end{array}$ & $\begin{array}{l}\# 18 \mathrm{C} \\
\text { NUMBER } \\
\text { SECTIONS }\end{array}$ & $\begin{array}{l}\# 29 \\
\text { RECTRU } \\
\text { INT. }\end{array}$ \\
\hline EDMONDS CC & YES & 3 & 30 & YES \\
\hline SHORELINE CC & YES & 5 & 54 & YES \\
\hline MT. HOOD CC & YES & 5 & 114 & YES \\
\hline TACOMA CC & YES & 3 & 60 & YES \\
\hline SPOKANE FALLS CC & YES & 5 & 88 & YES \\
\hline PORTLAND CC & YES & 5 & 342 & NO \\
\hline SKAGIT VALLEY CC & YES & 6 & 78 & YES \\
\hline SFATTLE NORTH CC & YES & 5 & 84 & No \\
\hline LANE CC & YES & 8 & 54 & No \\
\hline EVERETT CC & YES & 4 & 30 & YES \\
\hline CLACKAMAS CC & YES & 6 & 44 & NO \\
\hline YAKIMA VALLEY CC & YES & 4 & 70 & YES \\
\hline SEATTLE CENTRAL CC & YES & 5 & 94 & YES \\
\hline HIGHLINE CC & YES & 5 & 152 & No \\
\hline ROGUE CC & YES & 2 & 30 & NO \\
\hline CLARK CC & YES & 5 & 186 & NO \\
\hline PIERCE COLLEGE & YES & 6 & 36 & YES \\
\hline LINN-BENTON CC & YES & 1 & 8 & No \\
\hline BIG BEND CC & YES & 3 & 60 & YES \\
\hline CHEMEKETA CC & YES & 6 & 114 & NO \\
\hline CENTRAL OREGON CC & YES & 4 & 106 & YES \\
\hline WHATCOM CC & YES & 2 & 12 & NO \\
\hline SO.PUGET SOUND CC & YES & 4 & 22 & YES \\
\hline LOWER COLUMBIA CC & YES & 3 & 18 & NO \\
\hline WENATCHEE VALLEY CC & YES & 4 & 18 & NO \\
\hline SPOKANE CC & YES & 2 & 12 & YES \\
\hline COLUMBIA BASIN CC & YES & 3 & 72 & NO \\
\hline CLATSOP CC & YES & 2 & 8 & No \\
\hline OREGON COAST CC & YES & 5 & 34 & No \\
\hline BLUE MOUNTAIN CC & YES & 3 & 16 & NO \\
\hline
\end{tabular}




\begin{tabular}{|c|c|c|c|c|}
\hline NAME OF CC: & $\begin{array}{l}\# 20 \\
\text { STUDY } \\
\text { ABROAD }\end{array}$ & $\begin{array}{l}\# 21 \\
\text { NUMBER OF } \\
\text { STUDENTS }\end{array}$ & $\begin{array}{l}\# 22 \\
\text { DIFFERENT } \\
\text { COUNTRIES }\end{array}$ & $\begin{array}{l}\# 33 \mathrm{C} \\
\text { PERCENI } \\
\text { DEGREF }\end{array}$ \\
\hline EDMONDS CC & YES & 75 & 2 & $60 \%$ \\
\hline SHORELINE CC & YES & 170 & 7 & $70 \%$ \\
\hline MT. HOOD CC & YES & 10 & 1 & $25 \%$ \\
\hline TACOMA CC & YES & 4 & 1 & $25 \%$ \\
\hline SPOKANE FALIS CC & YES & 40 & $\overline{4}$ & $60 \%$ \\
\hline PORTLAND CC & YES & 5 & 1 & $0 \%$ \\
\hline SKAGIT VALLEY CC & YES & 10 & 1 & $80 \%$ \\
\hline SEATTLE NORTH CC & YES & 60 & 4 & $0 \%$ \\
\hline LANE CC & YES & 40 & 3 & $0 \%$ \\
\hline EVERETT CC & YES & 4 & 1 & $30 \%$ \\
\hline CLACKAMAS CC & YES & 25 & 2 & $0 \%$ \\
\hline YAKIMA VALLEY CC & YES & 15 & 1 & $95 \%$ \\
\hline SEATTLE CENTRAL CC & YES & 0 & $\overline{0}$ & $85 \%$ \\
\hline HIGHLINE CC & YES & 1 & 1 & $90 \%$ \\
\hline ROGUE CC & YES & 100 & 3 & $100 \%$ \\
\hline CLARK CC & YES & 6 & 1 & $10 \%$ \\
\hline PIERCE COLLEGE & No & 0 & 0 & $80 \%$ \\
\hline LINN-BENTON CC & YES & 5 & 1 & $5 \%$ \\
\hline BIG BEND CC & NO & 0 & 0 & $90 \%$ \\
\hline CHEMEKETA CC & YES & 6 & 1 & $50 \%$ \\
\hline CENTRAL OREGON CC & YES & 22 & 3 & $60 \%$ \\
\hline WHATCOM CC & YES & 2 & 1 & $90 \%$ \\
\hline SO.PUGET SOUND CC & YES & 10 & 1 & $80 \%$ \\
\hline LOWER COLUMBIA CC & YES & 5 & 1 & $75 \%$ \\
\hline WENATCHEE VALLEY CC & YES & 2 & 2 & $0 \%$ \\
\hline SPOKANE CC & NO & 0 & 0 & $40 \%$ \\
\hline COLUMBIA BASIN CC & YES & 0 & 0 & $0 \%$ \\
\hline CIATSOP CC & NO & 0 & 0 & $100 \%$ \\
\hline OREGON COAST CC & NO & 0 & 0 & $0 \%$ \\
\hline BLUE MOUNTAIN CC & No & 0 & 0 & $0 \%$ \\
\hline
\end{tabular}




$\begin{array}{lllll}\text { NAME OF CC: } & \# 23 & \# 24 & \# 25 & \# 35 \\ & \text { FACULTY } & \text { FACULTY } & \text { FACULTY } & \text { SISTER } \\ & \text { LIVED ABR. } & \text { EXCHANGES } & \text { TRAVEL ABR. COLIEGS }\end{array}$

$\begin{array}{lrrrr}\text { EDMONDS CC } & 15 & 2 & 40 & 2 \\ \text { SHORELINE CC } & 25 & 3 & 100 & 1 \\ \text { MT. HOOD CC } & 35 & 3 & 50 & 2 \\ \text { TACOMA CC } & 50 & 1 & 7 & 2 \\ \text { SPOKANE FALLS CC } & 7 & 4 & 30 & 0 \\ \text { PORTLAND CC } & 6 & 1 & 5 & 2 \\ \text { SKAGIT VALLEY CC } & 16 & 10 & 2.0 & 3 \\ \text { SEATTLE NORTH CC } & 10 & 4 & 70 & 0 \\ \text { LANE CC } & 25 & 0 & 75 & 0 \\ \text { EVERETT CC } & 5 & 4 & 35 & 1 \\ \text { CLACKAMAS CC } & 6 & 1 & 75 & 2 \\ \text { YAKIMA VALIEY CC } & 3 & 0 & 15 & 0 \\ \text { SEATTLE CENTRAL CC } & 3 & 2 & 25 & 0 \\ \text { HIGHLINE CC } & 20 & 1 & 25 & 0 \\ \text { ROGUE CC } & 1 & 1 & 10 & 0 \\ \text { CLARK CC } & 13 & 0 & 20 & 0 \\ \text { PIERCE COLLEGE } & 1 & 0 & 8 & 1 \\ \text { LINN-BENTON CC } & 10 & 8 & 20 & 0 \\ \text { BIG BEND CC } & 4 & 2 & 8 & 0 \\ \text { CHEMEKETA CC } & 10 & 1 & 40 & 2 \\ \text { CENTRAL OREGON CC } & 10 & 2 & 30 & 0 \\ \text { WHATCOM CC } & 6 & 0 & 3 & 0 \\ \text { SO.PUGET SOUND CC } & 1 & 0 & 10 & 2 \\ \text { LOWER COLUMBIA CC } & 3 & 0 & 7 & 0 \\ \text { WENATCHEE VALLEY CC } & 2 & 1 & 8 & 0 \\ \text { SPOKANE CC } & 0 & 0 & 5 & 0 \\ \text { COLUMBIA BASIN CC } & 0 & 0 & 5 & 0 \\ \text { CLATSOP CC } & 2 & 1 & 6 & 0 \\ \text { OREGON COAST CC } & 1 & 0 & 1 & 0 \\ \text { BLUE MOUNTAIN CC } & 2 & 1 & 4 & \end{array}$




\begin{tabular}{|c|c|c|c|c|}
\hline NAME OF CC: & $\begin{array}{l}\# 26 \\
\text { MILITARY } \\
\text { CONTRACTS }\end{array}$ & $\begin{array}{l}\# 27 \\
\text { FOREIGN } \\
\text { BR. CAMPUS }\end{array}$ & $\begin{array}{l}\# 27 \\
\text { NUMBER OF } \\
\text { COUNTRIES }\end{array}$ & $\begin{array}{l}\# 28 \\
\text { CANSTIDR } \\
\text { BRANCH }\end{array}$ \\
\hline EDMONDS CC & NO & YES & 1 & YES \\
\hline SHORELINE CC & NO & NO & 0 & NO \\
\hline MT. HOOD CC & NO & YES & 1 & No \\
\hline TACOMA CC & No & No & 0 & NO \\
\hline SPOKANE FALLS CC & YES & No & 0 & NO \\
\hline PORTLAND CC & No & No & 0 & NO \\
\hline SKAGIT VALLEY CC & No & NO & 0 & NO \\
\hline SEATTLE NORTH CC & No & NO & 0 & No \\
\hline LANE CC & NO & NO & 0 & No \\
\hline EVERETT CC & NO & NO & 0 & No \\
\hline CLACKAMAS CC & NO & NO & 0 & NO \\
\hline YAKIMA VALLEY CC & NO & NO & 0 & No \\
\hline SEATTLE CENTRAL CC & NO & No & 0 & No \\
\hline HIGHLINE CC & NO & NO & 0 & No \\
\hline ROGUE CC & No & NO & 0 & NO \\
\hline CLARK CC & No & No & 0 & NO \\
\hline PIERCE COLLEGE & No & No & 0 & NO \\
\hline LINN-BENTON CC & No & No & 0 & No \\
\hline BIG BEND CC & YES & No & 0 & YES \\
\hline CHEMEKETA CC & No & No & 0 & NO \\
\hline CENTRAL OREGON CC & No & No & 0 & No \\
\hline WHATCOM CC & No & NO & 0 & NO \\
\hline SO.PUGET SOUND CC & NO & NO & 0 & NO \\
\hline LOWER COLUMBIA CC & NO & No & 0 & NO \\
\hline WENATCHEE VALLEY CC & NO & No & 0 & NO \\
\hline SPOKANE CC & No & No & 0 & No \\
\hline COLUMBIA BASIN CC & NO & No & 0 & NO \\
\hline CLATSOP CC & No & No & 0 & No \\
\hline OREGON COAST CC & NO & No & 0 & No \\
\hline BLUE MOUNTAIN CC & No & No & 0 & No \\
\hline
\end{tabular}




$\begin{array}{lllll}\text { NAME OF CC: } & \# 26 & \# 30 \mathrm{a} & \# 30 \mathrm{~b} & \# 31 \mathrm{a} \\ & \text { DIFFERENT } & \text { INT. EDUC. NO. YEARS } & \text { ND. I.E. } \\ & \text { MIL. CONT. CURRICULUM INVOLVED } & \text { CIASSES }\end{array}$

\begin{tabular}{|c|c|c|c|c|}
\hline EDMONDS CC & 0 & YES & 2 & 5 \\
\hline SHORELINE CC & 0 & YES & 15 & 4 \\
\hline MT. HOOD CC & 0 & YES & 12 & 6 \\
\hline TACOMA CC & 0 & YES & 2 & 1 \\
\hline SPOKANE FALLS CC & 1 & YES & 6 & 5 \\
\hline PORTLAND CC & 0 & YES & 2 & 3 \\
\hline SKAGIT VALLEY CC & 0 & YES & 1 & 2 \\
\hline SEATTLE NORTH CC & 0 & NO & 0 & 5 \\
\hline LANE CC & 0 & YES & 10 & 1 \\
\hline EVERETT CC & 0 & YES & 2 & 4 \\
\hline CLACKAMAS CC & 0 & No & 0 & 2 \\
\hline YAKIMA VALLEY CC & 0 & No & 0 & 0 \\
\hline SEATTLE CENTRAL CC & 0 & No & 0 & 0 \\
\hline HIGHLINE CC & 0 & YES & 2 & 0 \\
\hline ROGUE CC & 0 & YES & 10 & 1 \\
\hline CLARK CC & 0 & No & 0 & 0 \\
\hline PIERCE COLLEGE & 0 & YES & 10 & 2 \\
\hline LINN-BENTON CC & 0 & YES & 7 & 3 \\
\hline BIG BEND CC & 2 & No & 0 & 2 \\
\hline CHEMEKETA CC & 0 & NO & 0 & 1 \\
\hline CENTRAL OREGON CC & 0 & NO & 0 & 0 \\
\hline WHATCOM CC & 0 & No & 0 & 0 \\
\hline SO.PUGET SOUND CC & 0 & NO & 0 & 0 \\
\hline LOWER COLUMBIA CC & 0 & No & 0 & 3 \\
\hline WENATCHEE VALLEY CC & 0 & NO & 0 & 0 \\
\hline SPOKANE CC & 0 & No & 0 & 0 \\
\hline COLUMBIA BASIN CC & 0 & NO & 0 & 0 \\
\hline CLATSOP CC & 0 & NO & 0 & 0 \\
\hline OREGON COAST CC & 0 & No & 0 & 0 \\
\hline BLUE MOUNTAIN CC & 0 & No & 0 & 0 \\
\hline
\end{tabular}




\begin{tabular}{|c|c|c|c|c|}
\hline NAME OF CC: & $\begin{array}{l}\# 31 \mathrm{~b} \\
\text { NO. I.E. } \\
\text { SECTIONS }\end{array}$ & $\begin{array}{l}\# 32 \\
\text { NO. NON-US } \\
\text { CLASSES }\end{array}$ & $\begin{array}{l}\# 34 a \\
\text { CONSORTIA } \\
\text { ABROAD }\end{array}$ & $\begin{array}{l}\# 34 \mathrm{~b} \\
\text { NUMBER } \\
\text { NATIONS }\end{array}$ \\
\hline EDMONDS CC & 15 & 14 & YES & 2 \\
\hline SHORELINE CC & 16 & 9 & YES & 1 \\
\hline MT. HOOD CC & 12 & 20 & YES & 1 \\
\hline TACOMA CC & 1 & 15 & YES & 1 \\
\hline SPOKANE FALLS CC & 11 & 8 & YES & 7 \\
\hline PORTLAND CC & 12 & 12 & YES & 1 \\
\hline SKAGIT VALLEY CC & 2 & 6 & YES & 2 \\
\hline SEATTLE NORTH CC & 22 & 14 & YES & 1 \\
\hline LANE CC & 6 & 3 & YES & 1 \\
\hline EVERETT CC & 4 & 1 & YES & 3 \\
\hline CLACKAMAS CC & 2 & 0 & YES & 5 \\
\hline YAKIMA VALLEY CC & 0 & 2 & YES & 1 \\
\hline SEATTLE CENTRAL CC & 0 & 7 & NO & 0 \\
\hline HIGHLINE CC & 0 & 2 & YES & 1 \\
\hline ROGUE CC & 2 & 3 & YES & 5 \\
\hline CLARK CC & 0 & 0 & YES & 1 \\
\hline PIERCE COLLEGE & 2 & 6 & NO & 0 \\
\hline LINN-BENTON CC & 3 & 0 & YES & 1 \\
\hline BIG BEND CC & 2 & 1 & No & 0 \\
\hline CHEMEKETA CC & 3 & 3 & YES & 2 \\
\hline CENTRAL OREGON CC & 0 & 1 & NO & 0 \\
\hline WHATCOM CC & 0 & 0 & YES & 1 \\
\hline SO.PUGET SOUND CC & 0 & 1 & YES & 1 \\
\hline LOWER COLUMBIA CC & 3 & 5 & YES & 1 \\
\hline WENATCHEE VALLEY CC & 0 & 4 & YES & 1 \\
\hline SPOKANE CC & 0 & 0 & NO & 0 \\
\hline COLUMBIA BASIN CC & 0 & 1 & YES & 1 \\
\hline CLATSOP CC & 0 & 0 & NO & 0 \\
\hline OREGON COAST CC & 0 & 4 & No & 0 \\
\hline BLUE MOUNTAIN CC & 0 & 0 & No & 0 \\
\hline
\end{tabular}




\begin{tabular}{|c|c|c|c|c|}
\hline NAME OF CC: & $\begin{array}{l}\text { \#36 } \\
\text { NO. I.E. } \\
\text { CONSORTIA }\end{array}$ & $\begin{array}{l}\# 37 \\
\text { NO. ASSIST } \\
\text { REQUESTS }\end{array}$ & $\begin{array}{l}\# 38 \\
\text { NO. I.E. } \\
\text { GRANTS }\end{array}$ & $\begin{array}{l}\# 39 \\
\text { M/S/L } \\
\text { FUNDING }\end{array}$ \\
\hline EDMONDS CC & 2 & 4 & 2 & SAME \\
\hline SHORELINE CC & 2 & 1 & 0 & MORE \\
\hline MT. HOOD CC & 2 & 0 & 1 & SAME \\
\hline TACOMA CC & 1 & 0 & 3 & MORE \\
\hline SPOKANE FALLS CC & 4 & 0 & 2 & MORE \\
\hline PORTLAND CC & 0 & 0 & 0 & MORE \\
\hline SKAGIT VALLEY CC & 3 & 0 & 0 & MORE \\
\hline SEATTLE NORTH CC & 2 & 0 & 1 & MORE \\
\hline LANE CC & 2 & 1 & 3 & SAME \\
\hline EVERETT CC & 1 & 2 & 2 & MORE \\
\hline CLACKAMAS CC & 3 & 0 & 0 & SAME \\
\hline YAKIMA VALLEY CC & 2 & 0 & 0 & SAME \\
\hline SEATTLE CENTRAL CC & 0 & 0 & 0 & SAME \\
\hline HIGHLINE CC & 1 & 0 & 0 & MORE \\
\hline ROGUE CC & 1 & 0 & 0 & SAME \\
\hline CLARK CC & 2 & 0 & 0 & SAME \\
\hline PIERCE COLLEGE & 0 & 0 & 0 & MORE \\
\hline LINN-BENTON CC & 3 & 0 & 0 & SAME \\
\hline BIG BEND CC & 0 & 0 & 0 & SAME \\
\hline CHEMEKETA CC & 2 & 0 & 0 & SAME \\
\hline CENTRAL OREGON CC & 0 & 0 & 0 & SAME \\
\hline WHATCOM CC & 1 & 0 & 0 & SAME \\
\hline SO.PUGET SOUND $C C$ & 1 & 0 & 0 & MORE \\
\hline LOWER COLUMBIA CC & 1 & 0 & 0 & SAME \\
\hline WENATCHEE VALLEY CC & 1 & 0 & 0 & LESS \\
\hline SPOKANE CC & 1 & 0 & 0 & SAME \\
\hline COLUMBIA BASIN CC & 1 & 0 & 0 & SAME \\
\hline CLATSOP CC & 0 & 0 & 0 & SAME \\
\hline OREGON COAST CC & 0 & 0 & 0 & SAME \\
\hline BLUE MOUNTAIN CC & 0 & 0 & 0 & SAME \\
\hline
\end{tabular}


NAME OF CC:

\#41

MORE/SAME/LESS

TOTAL

INVOLVEMENT

POINTS

EDMONDS CC

MORE

280

SHORELINE CC

MORE

273

MT. HOOD CC

TACOMA CC

MORE

215

SPOKANE FALLS CC

MORE

186

PORTLAND CC

MORE

175

MORE

162

SKAGIT VALLEY CC

MORE

155

SEATTLE NORTH CC

MORE

145

ILANE CC

EVERETT CC

CLACKAMAS CC

MORE

139

MORE

133

MORE

128

YAKIMA VALLEY CC

SAME

119

SEATTLE CENTRAL CC

MORE

116

HIGHLINE CC

ROGUE CC

MORE

115

109

CLIARK CC

MORE

107

PIERCE COLLEGE

MORE

MORE

99

LINN-BENTON CC

MORE

97

MORE

CHEMEKETA CC

MORE

95

95

CENTRAL OREGON CC

MORE

WHATCOM CC

MORE

87

80

SO.PUGET SOUND CC

MORE

72

MORE

66

WENATCHEE VALLEY CC

MORE

43

SPOKANE CC

MORE

COLUMBIA BASIN CC

MORE

39

CLATSOP CC

MORE

38

24

OREGON COAST CC

SAME

20

BLUE MOUNTAIN CC

SAME 
APPENDIX E

CONVERTED SURVEY RESULTS 
QUESTION \#I

NAME OF CC:

$\begin{array}{ll}\text { EDMONDS CC } & \text { WA } \\ \text { SHORELINE CC } & \text { WA } \\ \text { MT. HOOD CC } & \text { OR } \\ \text { TACOMA CC } & \text { WA } \\ \text { SPOKANE FALLS CC } & \text { WA } \\ \text { PORTLAND CC } & \text { OR } \\ \text { SKAGIT VALLEY CC } & \text { WA } \\ \text { SEATTLE NORTH CC } & \text { WA } \\ \text { LANE CC CC } & \text { OR } \\ \text { EVERETT CC } & \text { WA } \\ \text { CLACKAMAS CC } & \text { OR } \\ \text { YAKIMA VALLEY CC } & \text { WA } \\ \text { SEATTLE CENTRAL CC } & \text { WA } \\ \text { HIGHLINE CC } & \text { WA } \\ \text { ROGUE CC } & \text { OR } \\ \text { CLARK CC } & \text { WA } \\ \text { PIERCE COLLEGE } & \text { WA } \\ \text { LINN-BENTON CC } & \text { WA } \\ \text { BIG BEND CC } & \text { WA } \\ \text { CHEMEKETA CC } & \text { OR } \\ \text { CENTRAL OREGON CC } & \text { OR } \\ \text { WHATCOM CC } & \text { WA } \\ \text { SO. PUGET SOUND CC } & \text { WA } \\ \text { LOWER COLUMBIA CC } & \text { WA } \\ \text { WENATCHEE VALLEY CC WA } \\ \text { SPOKANE CC } & \text { WA } \\ \text { COLUMBIA BASIN CC } & \text { WA } \\ \text { CLATSOP CC } & \text { OR } \\ \text { OREGON COAST CC } & \text { OR } \\ \text { BLUE MOUNTAIN CC } & \text { OR } \\ & \end{array}$ $\begin{array}{ll}\# 3 \\ \text { STATE } & \text { RESPONDENT }\end{array}$

\#4

STUDENT
FTE'S

\#6

FACULTY

FTE'S

4,500

4,400

6,100

3,250

5,823

13,929

2,600

3,477

8,200

3,600

4,364

2,900

5,105

4,613

1,400

4,500

4,000

4,500

1,183

7,600

2,000

1,400

2,000

2,109

1,813

5,397

3,493

925

100

1,650
ASSOC DEAN

PRESIDENT

DEAN INST

ASST VP

PRESIDENT
\#7

$\mathrm{P} / \mathrm{T}$

FIC.

$\begin{array}{rr}100 & 300 \\ 150 & 160 \\ 181 & 330 \\ 90 & 160 \\ 158 & 716 \\ 372 & 995 \\ 110 & 200 \\ 160 & 200 \\ 280 & 450 \\ 180 & 120 \\ 150 & 411 \\ 105 & 250 \\ 123 & 240 \\ 115 & 186 \\ 60 & 200 \\ 133 & 297 \\ 90 & 325 \\ 130 & 200 \\ 46 & 60 \\ 220 & 500 \\ 110 & 100 \\ 42 & 60 \\ 65 & 135 \\ 105 & 40 \\ 61 & 110 \\ 219 & 303 \\ 98 & 215 \\ 35 & 30 \\ 2 & 50 \\ 73 & 220 \\ & \end{array}$




\begin{tabular}{|c|c|c|c|c|}
\hline NAME OF CC: & $\begin{array}{l}\# 5 \\
\text { NO. INT'L } \\
\text { STUDENTS } \\
(1 P T: 10)\end{array}$ & $\begin{array}{l}\# 8 \\
\text { FOREIGN } \\
\text { BORN FAC. } \\
\text { (ACTUAL) }\end{array}$ & $\begin{array}{l}\text { \#9 } \\
\text { YEARS } \\
\text { INVOLVED } \\
\text { (ACTUAL) }\end{array}$ & $\begin{array}{l}\# 12 \\
\text { ADMIN } \\
\text { TIME } \\
\text { 1PT:25\% }\end{array}$ \\
\hline EDMONDS CC & 45.00 & 5 & 12 & 8.00 \\
\hline SHORELINE CC & 29.00 & 30 & 20 & 0.80 \\
\hline MT. HOOD CC & 5.30 & 6 & 16 & 8.40 \\
\hline TACOMA CC & 12.40 & 10 & 23 & 2.00 \\
\hline SPOKANE FALLS CC & 6.20 & 2 & 6 & 0.50 \\
\hline PORTLAND CC & 12.80 & 15 & 12 & 0.50 \\
\hline SKAGIT VALLEY CC & 5.50 & 8 & 25 & 0.20 \\
\hline SEATTLE NORTH CC & 10.00 & 4 & 10 & 1.00 \\
\hline LANE CC & 17.20 & 0 & 10 & 0.00 \\
\hline EVERETT CC & 5.00 & 5 & 15 & 0.50 \\
\hline CLACKAMAS CC & 1.70 & 6 & 25 & 0.20 \\
\hline YAKIMA VALLEY CC & 10.00 & 10 & 25 & 0.00 \\
\hline SEATTLE CENTRAL CC & 12.00 & 23 & 1 & 0.00 \\
\hline HIGHLINE CC & 8.80 & 5 & 15 & 0.00 \\
\hline ROGUE CC & 1.20 & 3 & 10 & 0.20 \\
\hline CLARK CC & 10.00 & 5 & 10 & 1.60 \\
\hline PIERCE COLLEGE & 3.00 & 5 & 15 & 2.00 \\
\hline LINN-BENTON CC & 9.50 & 3 & 13 & 1.00 \\
\hline BIG BEND CC & 18.80 & 1 & 25 & 0.20 \\
\hline CHEMEKETA CC & 12.50 & 5 & 5 & 0.20 \\
\hline CENTRAL OREGON CC & 1.70 & 2 & 10 & 0.00 \\
\hline WHATCOM CC & 2.50 & 2 & 2 & 1.00 \\
\hline SO.PUGET SOUND CC & 1.30 & 3 & 3 & 0.60 \\
\hline LOWER COLUMBIA CC & 0.10 & 0 & 15 & 1.00 \\
\hline WENATCHEE VALLEY CC & 0.00 & 2 & 2 & 0.20 \\
\hline SPOKANE CC & 4.40 & 2 & 3 & 0.40 \\
\hline COLUMBIA BASIN CC & 1.00 & 1 & 0 & 0.00 \\
\hline CLATSOP CC & 0.10 & 0 & 0 & 0.00 \\
\hline OREGON COAST CC & 0.00 & 0 & 0 & 0.00 \\
\hline BLUE MOUNTAIN CC & 0.10 & 1 & 0 & 0.00 \\
\hline
\end{tabular}


NAME OF CC:

$\begin{array}{llll}\# 11 & \# 13 & \# 14 & \# 15 \\ \text { NON-ADM. } & \text { ADVISOR } & \text { I.E. FAC. } & \text { INSTIT. } \\ \text { TIME } & \text { TIME } & \text { TIME } & \text { HRICRIY } \\ (1 P T: 25 \%) & (1 P T: 25 \%) & \text { (1PT:25\%) } & (1 I-5 H)\end{array}$

EDMONDS CC
SHORELINE CC
MT. HOOD CC
TACOMA CC
SPOKANE FALLS CC
PORTLAND CC
SKAGIT VALLEY CC
SEATTLE NORTH CC
LANE CC
EVERETT CC
CLACKAMAS CC
YAKIMA VALLEY CC
SEATTLE CENTRAL CC
HIGHLINE CC
ROGUE CC
CLARK CC
PIERCE COLLEGE
LINN-BENTON CC
BIG BEND CC
CHENEKETA CC
CENTRAL OREGON CC
WHATCOM CC
SO.PUGET SOUND CC
LOWER COLUMBIA CC
WENATCHEE VALLEY CC
SPOKANE CC
COLUMBIA BASIN CC
CLATSOP CC
OREGON COAST CC
BLUE MOUNTAIN CC

36.00
12.00
10.00
8.00
8.00
0.00
6.00
0.00
0.00
16.00
8.00
8.00
0.00
0.00
0.00
8.00
4.00
0.00
0.00
0.00
0.00
4.00
5.00
0.00
0.00
8.00
0.00
0.00
0.00
0.00

16.00

4.00

4.40

4.00

4.00

4.00

2.00

4.00

2.00

6.00

1.00

4.00

0.00

0.40

0.40

2.00

2.00

0.00

0.40

0.80

0.20

2.00

4.00

0.40

0.00

0.80

0.00

0.80

0.00

0.00

$\begin{array}{rr}12.00 & 4 \\ 6.60 & 3 \\ 4.00 & 3 \\ 4.00 & 4 \\ 20.00 & 4 \\ 13.20 & 2 \\ 5.00 & 4 \\ 4.00 & 3 \\ 0.00 & 4 \\ 6.00 & 4 \\ 20.00 & 3 \\ 5.00 & 3 \\ 0.00 & 3 \\ 0.00 & 4 \\ 3.00 & 3 \\ 0.00 & 3 \\ 6.60 & 4 \\ 0.00 & 3 \\ 0.00 & 3 \\ 0.00 & 3 \\ 1.00 & 3 \\ 15.00 & 3 \\ 0.00 & 3 \\ 2.00 & 2 \\ 0.00 & 2 \\ 0.00 & 3 \\ 0.00 & 2 \\ 0.00 & 1 \\ 0.00 & 1 \\ 0.00 & 2\end{array}$




\begin{tabular}{|c|c|c|c|c|}
\hline NAME OF CC: & $\begin{array}{l}\# 16 \\
\text { ESL } \\
\text { PROGRAM } \\
(1: \text { YES })\end{array}$ & $\begin{array}{l}\# 16 \\
\text { ENL } \\
\text { PROGRAM } \\
(1: \text { YES })\end{array}$ & $\begin{array}{l}\# 17 \\
\text { ESI/ENL } \\
\text { STUDENTS } \\
(1 \mathrm{PT}: 100)\end{array}$ & $\begin{array}{l}\# 19 \\
\text { MISSION } \\
\text { STATMT } \\
\text { (5:YES) }\end{array}$ \\
\hline EDMONDS CC & 1 & 1 & 18.00 & 5 \\
\hline SHORELINE CC & 1 & 0 & 3.25 & 5 \\
\hline MT. HOOD CC & 1 & 1 & 10.00 & 5 \\
\hline TACOMA CC & 1 & 0 & 2.50 & 0 \\
\hline SPOKANE FALLS CC & 1 & 1 & 6.50 & 5 \\
\hline PORTLAND CC & 1 & 1 & 4.75 & 5 \\
\hline SKAGIT VALLEY CC & 1 & 1 & 2.00 & 0 \\
\hline SEATTLE NORTH CC & 1 & 1 & 14.18 & 0 \\
\hline LANE CC & 1 & 0 & 1.45 & 5 \\
\hline EVERETT CC & 1 & 1 & 0.00 & 5 \\
\hline CLACKAMAS CC & 1 & 0 & 4.00 & 0 \\
\hline YAKIMA VALLEY CC & 1 & 0 & 0.70 & 0 \\
\hline SEATTLE CENTRAL CC & 1 & 1 & 18.50 & 5 \\
\hline HIGHLINE CC & 1 & 0 & 0.65 & 5 \\
\hline ROGUE CC & 1 & 1 & 0.50 & 5 \\
\hline CLARK CC & 1 & 1 & 6.48 & 0 \\
\hline PIERCE COLLEGE & 1 & 1 & 2.00 & 0 \\
\hline LINN-BENTON CC & 1 & 1 & 4.00 & 0 \\
\hline BIG BEND CC & 1 & 0 & 0.30 & 5 \\
\hline CHEMEKETA CC & 1 & 1 & 0.00 & 5 \\
\hline CENTRAL OREGON CC & 1 & 1 & 4.20 & 5 \\
\hline WHATCOM CC & 1 & 0 & 1.50 & 0 \\
\hline SO.PUGET SOUND CC & 1 & 0 & 2.03 & 0 \\
\hline LOWER COLUMBIA CC & 1 & 0 & 2.00 & 0 \\
\hline WENATCHEE VALLEY CC & 1 & 0 & 4.80 & 0 \\
\hline SPOKANE CC & 0 & 0 & 0.00 & 0 \\
\hline COLUMBIA BASIN CC & 1 & 0 & 5.25 & 0 \\
\hline CLATSOP CC & 1 & 0 & 1.02 & 0 \\
\hline OREGON COAST CC & 1 & 0 & 1.53 & 0 \\
\hline BLUE MOUNTAIN CC & 1 & 0 & 2.21 & 0 \\
\hline
\end{tabular}




\begin{tabular}{|c|c|c|c|c|}
\hline NAME OF CC: & $\begin{array}{l}\# 18 \mathrm{a} \\
\text { FOREIGN } \\
\text { LANGUAGES } \\
\text { (1:YES) }\end{array}$ & $\begin{array}{l}\# I 8 \mathrm{~b} \\
\text { DIFFERENT } \\
\text { LANGUAGES } \\
\text { (ACTUAL) }\end{array}$ & $\begin{array}{l}\text { \#18c } \\
\text { NUMBER } \\
\text { SECTIONS } \\
(1 \mathrm{PT}: 5)\end{array}$ & $\begin{array}{l}\text { \#29 } \\
\text { RECRIJT } \\
\text { INT. ST. } \\
\text { (ACILAL) }\end{array}$ \\
\hline EDMONDS CC & 1 & 3 & 3.00 & 1 \\
\hline SHORELINE CC & 1 & 5 & 6.40 & 1 \\
\hline MT. HOOD CC & 1 & 5 & 11.40 & 1 \\
\hline TACOMA CC & 1 & 3 & 6.00 & 1 \\
\hline SPOKANE FALLS CC & 1 & 5 & 8.80 & 1 \\
\hline PORTLAND CC & 1 & 5 & 34.20 & 0 \\
\hline SKAGIT VALLEY CC & 1 & 6 & 7.80 & 1 \\
\hline SEATTLE NORTH CC & 1 & 5 & 8.40 & 0 \\
\hline LANE CC & 1 & 8 & 5.40 & 0 \\
\hline EVERETT CC & 1 & 4 & 3.00 & 1 \\
\hline CLACKAMAS CC & 1 & 6 & 4.40 & 0 \\
\hline YAKIMA VALLEY CC & 1 & 4 & 7.00 & 1 \\
\hline SEATTLE CENTRAL CC & 1 & 5 & 9.40 & 1 \\
\hline HIGHLINE CC & 1 & 5 & 15.20 & 0 \\
\hline ROGUE CC & 1 & 2 & 3.00 & 0 \\
\hline CLARK CC & 1 & 5 & 18.60 & 0 \\
\hline PIERCE COLLEGE & 1 & 6 & 3.60 & 1 \\
\hline LINN-BENTON CC & 1 & 1 & 0.80 & 0 \\
\hline BIG BEND CC & 1 & 3 & 6.00 & 1 \\
\hline CHEMEKETA CC & 1 & 6 & 11.40 & 0 \\
\hline CENTRAL OREGON CC & 1 & 4 & 10.60 & 0 \\
\hline WHATCOM CC & 1 & 2 & 1.20 & 1 \\
\hline SO.PUGET SOUND CC & 1 & 4 & 2.20 & 1 \\
\hline LOWER COLUMBIA CC & 1 & 3 & 1.80 & 0 \\
\hline WENATCHEE VALLEY CC & 1 & 4 & 1.80 & 0 \\
\hline SPOKANE CC & 1 & 2 & 1.20 & 1 \\
\hline COLUMBIA BASIN CC & 1 & 3 & 7.20 & 0 \\
\hline CLATSOP CC & 1 & 2 & 0.80 & 0 \\
\hline OREGON COAST CC & 1 & 5 & 3.40 & 0 \\
\hline BLUE MOUNTAIN CC & 1 & 3 & 1.60 & 0 \\
\hline
\end{tabular}




\begin{tabular}{|c|c|c|c|c|}
\hline NAME OF CC: & $\begin{array}{l}\# 20 \\
\text { STUDY } \\
\text { ABROAD } \\
\text { (ACTUAL) }\end{array}$ & $\begin{array}{l}\# 21 \\
\text { NUMBER OF } \\
\text { STUDENTS } \\
(1 \mathrm{PT}: 5)\end{array}$ & $\begin{array}{l}\# 22 \\
\text { DIFFERENT } \\
\text { COUNTRIES } \\
\text { (ACTUAL) }\end{array}$ & $\begin{array}{l}\# 33 \mathrm{C} \\
\text { PERCENT } \\
\text { DEGREE } \\
(1: 10 \%)\end{array}$ \\
\hline EDMONDS CC & 1 & 15.00 & 2 & 6.0 \\
\hline SHORELINE CC & 1 & 34.00 & 7 & 7.0 \\
\hline MT. HOOD CC & 1 & 2.00 & 1 & 2.5 \\
\hline TACOMA CC & 1 & 0.80 & 1 & 2.5 \\
\hline SPOKANE FALLS CC & 1 & 8.00 & 4 & 6.0 \\
\hline PORTLAND CC & 1 & 1.00 & 1 & 0.0 \\
\hline SKAGIT VALLEY CC & 1 & 2.00 & 1 & 8.0 \\
\hline SEATTLE NORTH CC & 1 & 12.00 & 4 & 0.0 \\
\hline LANE CC & 1 & 8.00 & 3 & 0.0 \\
\hline EVERETT CC & 1 & 0.80 & 1 & 3.0 \\
\hline CLACKAMAS CC & 1 & 5.00 & 2 & 0.0 \\
\hline YAKIMA VALLEY CC & 1 & 3.00 & 1 & 9.5 \\
\hline SEATTLE CENTRAL CC & 1 & 0.00 & 0 & 8.5 \\
\hline HIGHLINE CC & 1 & 0.20 & 1 & 9.0 \\
\hline ROGUE CC & 1 & 20.00 & 3 & 10.0 \\
\hline CLARK CC & 1 & 1.20 & 1 & 1.0 \\
\hline PIERCE COLLEGE & 0 & 0.00 & 0 & 8.0 \\
\hline LINN-BENTON CC & 1 & 1.00 & 1 & 0.5 \\
\hline BIG BEND CC & 0 & 0.00 & 0 & 9.0 \\
\hline CHEMEKETA CC & 1 & 1.20 & 1 & 5.0 \\
\hline CENTRAL OREGON CC & 1 & 4.40 & 3 & 6.0 \\
\hline WHATCOM CC & 1 & 0.40 & 1 & 9.0 \\
\hline SO.PUGET SOUND CC & 1 & 2.00 & 1 & 8.0 \\
\hline LOWER COLUMBIA CC & 1 & 1.00 & 1 & 7.5 \\
\hline WENATCHEE VALLEY CC & 1 & 0.40 & 2 & 0.0 \\
\hline SPOKANE CC & 0 & 0.00 & 0 & 4.0 \\
\hline COLUMBIA BASIN CC & 1 & 0.00 & 0 & 0.0 \\
\hline CLATSOP CC & 0 & 0.00 & 0 & 10.0 \\
\hline OREGON COAST CC & 0 & 0.00 & 0 & 0.0 \\
\hline BLUE MOUNTAIN CC & 0 & 0.00 & 0 & 0.0 \\
\hline
\end{tabular}




$\begin{array}{lllll}\text { NAME OF CC: } & \# 23 & \# 24 & \# 25 & \# 35 \\ & \text { FACULTY } & \text { FACULTY } & \text { FACULTY } & \text { SISTER } \\ & \text { LIVED ABR. } & \text { EXCHANGES } & \text { TRAVEL ABR. COIIRGS } \\ & \text { (ACTUAL) } & \text { (ACTUAL) } & \text { (1PT:10) } & \text { (ACTUAL) }\end{array}$

\begin{tabular}{|c|c|}
\hline 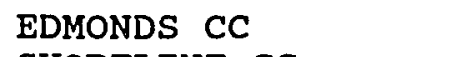 & \\
\hline SHORELINE CC & \\
\hline MT. HOOD CC & \\
\hline $\begin{array}{l}\text { TACOMA CC } \\
\text { SPOKANE FALLS CC }\end{array}$ & \\
\hline PORTLAND CC & \\
\hline SKAGIT VALLEY CC & \\
\hline SEATTLE NORTH CC & \\
\hline LANE CC & \\
\hline EVERETT CC & \\
\hline CLACKAMAS CC & \\
\hline YAKIMA VALLEY CC & \\
\hline SEATTLE CENTRAL CC & \\
\hline HIGHLINE CC & \\
\hline ROGUE CC & \\
\hline CLARK CC & \\
\hline PIERCE COIJLEGE & \\
\hline LINN-BENTON CC & \\
\hline BIG BEND CC & \\
\hline CHEMEKETA CC & \\
\hline CENTRAL OREGON CC & \\
\hline WHATCOM CC & \\
\hline SO.PUGET SOUND CC & \\
\hline LOWER COLUMBIA CC & \\
\hline WENATCHEE VALLEY CC & \\
\hline SPOKANE CC & \\
\hline COLUMBIA BASIN CC & \\
\hline CLATSOF & \\
\hline SON & \\
\hline TUF MOUNTA TN $\mathrm{CC}$ & \\
\hline
\end{tabular}

$\begin{array}{rrr}2 & 4.00 & 2 \\ 3 & 10.00 & 1 \\ 3 & 5.00 & 2 \\ 1 & 0.70 & 2 \\ 4 & 3.00 & 0 \\ 1 & 0.50 & 2 \\ 10 & 2.00 & 3 \\ 4 & 7.00 & 0 \\ 0 & 7.50 & 0 \\ 4 & 3.50 & 1 \\ 1 & 7.50 & 2 \\ 0 & 1.50 & 0 \\ 2 & 2.50 & 0 \\ 1 & 2.50 & 0 \\ 1 & 1.00 & 0 \\ 0 & 2.00 & 0 \\ 0 & 0.80 & 1 \\ 8 & 2.00 & 0 \\ 2 & 0.80 & 0 \\ 1 & 4.00 & 2 \\ 2 & 3.00 & 0 \\ 0 & 0.30 & 0 \\ 0 & 1.00 & 2 \\ 0 & 0.70 & 0 \\ 1 & 0.80 & 0 \\ 0 & 0.50 & 0 \\ 0 & 0.50 & 0 \\ 1 & 0.60 & 0 \\ 0 & 0.10 & 0 \\ 1 & 0.40 & 0\end{array}$


NAME OF CC:

\section{\#26}

MILITARY CONTRACTS (5PTS:1)

\section{\#27}

FOREIGN

BR. CAMPUS

(10PTS: 1)
\#27

NUMBER OF

COUNTRIES

(ACTUAL)
\#28

CONSTIDER BRANCH

(ACIUAL)

$\begin{array}{ll}\text { EDMONDS CC } & 0 \\ \text { SHORELINE CC } & 0 \\ \text { MT. HOOD CC } & 0 \\ \text { TACOMA CC } & 0 \\ \text { SPOKANE FALLS CC } & 5 \\ \text { PORTLAND CC } & 0 \\ \text { SKAGIT VALLEY CC } & 0 \\ \text { SEATTLE NORTH CC } & 0 \\ \text { LANE CC CC } & 0 \\ \text { EVERETT CC } & 0 \\ \text { CLACKAMAS CC } & 0 \\ \text { YAKIMA VALIEY CC } & 0 \\ \text { SEATTLE CENTRAL CC } & 0 \\ \text { HIGHLINE CC } & 0 \\ \text { ROGUE CC } & 0 \\ \text { CLARK CC } & 0 \\ \text { PIERCE COLLEGE } & 0 \\ \text { LINN-BENTON CC } & 0 \\ \text { BIG BEND CC } & 5 \\ \text { CHEMEKETA CC } & 0 \\ \text { CENTRAL OREGON CC } & 0 \\ \text { WHATCOM CC } & 0 \\ \text { SO.PUGET SOUND CC } & 0 \\ \text { LOWER COLUMBIA CC } & 0 \\ \text { WENATCHEE VALLEY CC } & 0 \\ \text { SPOKANE CC } & 0 \\ \text { COLUMBIA BASIN CC } & 0 \\ \text { CLATSOP CC } & 0 \\ \text { OREGON COAST CC } & 0 \\ \text { BLUE MOUNTAIN CC } & 0\end{array}$

1

0

0

0

0

0

0

0

0

0

0

0

0

0

0

0

0

0

1

0

0

0

0

0

0

0

0

0

0 
NAME OF CC:

$$
\begin{array}{llll}
\# 26 & \# 30 \mathrm{a} & \# 30 \mathrm{~b} & \# 31 \mathrm{a} \\
\text { DIFFERENT } & \text { INT. EDUC. } & \text { NO. YEARS } & \text { ND. I.E. } \\
\text { MIL. CONT. } & \text { CURRICULUM } & \text { INVOLVED } & \text { CLASSES } \\
\text { (ACTUAL) } & \text { (ACTUAL) } & \text { (ACTUAL) } & \text { (ACTULI) }
\end{array}
$$

\begin{tabular}{|c|c|c|c|c|}
\hline EDMONDS CC & 0 & 1 & 2 & 5 \\
\hline SHORELINE CC & 0 & 1 & 15 & 4 \\
\hline MT. HOOD CC & 0 & 1 & 12 & 6 \\
\hline TACOMA CC & 0 & 1 & 2 & 1 \\
\hline SPOKANE FALLS CC & 1 & 1 & 6 & 5 \\
\hline PORTLAND CC & 0 & 1 & 2 & 3 \\
\hline SKAGIT VALLEY CC & 0 & 1 & 1 & 2 \\
\hline SEATTLE NORTH CC & 0 & 0 & 0 & 5 \\
\hline LANE CC & 0 & 1 & 10 & 1 \\
\hline EVERETT CC & 0 & 1 & 2 & 4 \\
\hline CLACKAMAS CC & 0 & 0 & 0 & 2 \\
\hline YAKIMA VALLEY CC & 0 & 0 & 0 & 0 \\
\hline SEATTLE CENTRAL CC & 0 & 0 & 0 & 0 \\
\hline HIGHLINE CC & 0 & 1 & 2 & 0 \\
\hline ROGUE CC & 0 & 1 & 10 & 1 \\
\hline CLARK CC & 0 & 0 & 0 & 0 \\
\hline PIERCE COLLEGE & 0 & 1 & 10 & 2 \\
\hline LINN-BENTON CC & 0 & 1 & 7 & 3 \\
\hline BIG BEND CC & 2 & 0 & 0 & 2 \\
\hline CHEMEKETA CC & 0 & 0 & 0 & 1 \\
\hline CENTRAL OREGON CC & 0 & 0 & 0 & 0 \\
\hline WHATCOM CC & 0 & 0 & 0 & 0 \\
\hline SO.PUGET SOUND CC & 0 & 0 & 0 & 0 \\
\hline LOWER COLUMBIA CC & 0 & 0 & 0 & 3 \\
\hline WENATCHEE VALLEY CC & 0 & 0 & 0 & 0 \\
\hline SPOKANE CC & 0 & 0 & 0 & 0 \\
\hline COLUMBIA BASIN CC & 0 & 0 & 0 & 0 \\
\hline CLATSOP CC & 0 & 0 & 0 & 0 \\
\hline OREGON COAST CC & 0 & 0 & 0 & 0 \\
\hline BLUE MOUNTAIN CC & 0 & 0 & 0 & 0 \\
\hline
\end{tabular}


NAME OF CC:

$\begin{array}{llll}\# 31 \mathrm{~b} & \# 32 & \# 34 \mathrm{a} & \# 34 \mathrm{~b} \\ \text { NO. I.E. } & \text { NO. NON-US } & \text { CONSORTIA } & \text { NUMBER } \\ \text { SECTIONS } & \text { CLASSES } & \text { ABROAD } & \text { NATIONS } \\ (1 P T: 5) & \text { (ACTUAL) } & (1: \text { YES }) & \text { (ACIUL) }\end{array}$

$\begin{array}{ll}\text { EDMONDS CC } & 3.00 \\ \text { SHORELINE CC } & 3.20 \\ \text { MT. HOOD CC } & 2.40 \\ \text { TACOMA CC } & 0.20 \\ \text { SPOKANE FALLS CC } & 2.20 \\ \text { PORTIAND CC } & 2.40 \\ \text { SKAGIT VALLEY CC } & 0.40 \\ \text { SEATTLE NORTH CC } & 4.40 \\ \text { LANE CC CC } & 1.20 \\ \text { EVERETT CC } & 0.80 \\ \text { CLACKAMAS CC } & 0.40 \\ \text { YAKIMA VALLEY CC } & 0.00 \\ \text { SEATTLE CENTRAL CC } & 0.00 \\ \text { HIGHLINE CC } & 0.00 \\ \text { ROGUE CC } & 0.40 \\ \text { CLARK CC } & 0.00 \\ \text { PIERCE COLLEGE } & 0.40 \\ \text { LINN-BENTON CC } & 0.60 \\ \text { BIG BEND CC } & 0.40 \\ \text { CHEMEKETA CC } & 0.60 \\ \text { CENTRAL OREGON CC } & 0.00 \\ \text { WHATCOM CC } & 0.00 \\ \text { SO.PUGET SOUND CC } & 0.00 \\ \text { LOWER COLUMBIA CC } & 0.60 \\ \text { WENATCHEE VALLEY CC } & 0.00 \\ \text { SPOKANE CC } & 0.00 \\ \text { COLUMBIA BASIN CC } & 0.00 \\ \text { CLATSOP CC } & 0.00 \\ \text { OREGON COAST CC } & 0.00 \\ \text { BLUE MOUNTAIN CC } & 0.00\end{array}$

$\begin{array}{rll}14 & 1 & 2 \\ 9 & 1 & 1 \\ 20 & 1 & 1 \\ 15 & 1 & 1 \\ 8 & 1 & 7 \\ 12 & 1 & 1 \\ 6 & 1 & 2 \\ 14 & 1 & 1 \\ 3 & 1 & 1 \\ 1 & 1 & 3 \\ 0 & 1 & 5 \\ 2 & 1 & 1 \\ 7 & 0 & 0 \\ 2 & 1 & 1 \\ 3 & 1 & 5 \\ 0 & 1 & 1 \\ 6 & 0 & 0 \\ 0 & 1 & 1 \\ 1 & 0 & 0 \\ 3 & 1 & 2 \\ 1 & 0 & 0 \\ 0 & 1 & 1 \\ 1 & 1 & 1 \\ 5 & 1 & 1 \\ 4 & 1 & 1 \\ 0 & 0 & 0 \\ 1 & 1 & 1 \\ 0 & 0 & 0 \\ 4 & 0 & 0 \\ 0 & 0 & \end{array}$


NAME OF CC:

$$
\begin{array}{llll}
\# 36 & \# 37 & \# 38 & \# 39 \\
\text { NO. I.E. } & \text { NO. ASSIST } & \text { NO. I.E. } & \text { M/S / I } \\
\text { CONSORTIA } & \text { REQUESTS } & \text { GRANTS } & \text { FUNDING } \\
\text { (ACTUAL) } & \text { (ACTUAL) } & \text { (ACTUAL) } & \text { M:2;S:1) }
\end{array}
$$

\begin{tabular}{|c|c|c|c|c|}
\hline EDMONDS CC & 2 & 4 & 2 & 1 \\
\hline SHORELINE CC & 2 & 1 & 0 & 2 \\
\hline MT. HOOD CC & 2 & 0 & 1 & 1 \\
\hline TACOMA CC & 1 & 0 & 3 & 2 \\
\hline SPOKANE FALLS CC & 4 & 0 & 2 & 2 \\
\hline PORTLAND CC & 0 & 0 & 0 & 2 \\
\hline SKAGIT VALLEY CC & 3 & 0 & 0 & 2 \\
\hline SEATTLE NORTH CC & 2 & 0 & 1 & 2 \\
\hline LANE CC & 2 & 1 & 3 & 1 \\
\hline EVERETT CC & 1 & 2 & 2 & 2 \\
\hline CLACKAMAS CC & 3 & 0 & 0 & 1 \\
\hline YAKIMA VALLEY CC & 2 & 0 & 0 & 1 \\
\hline SEATTLE CENTRAL CC & 0 & 0 & 0 & 1 \\
\hline HIGHLINE CC & 1 & 0 & 0 & 2 \\
\hline ROGUE CC & 1 & 0 & 0 & 1 \\
\hline CLARK CC & 2 & 0 & 0 & 1 \\
\hline PIERCE COLLEGE & 0 & 0 & 0 & 2 \\
\hline LINN-BENTON CC & 3 & 0 & 0 & 1 \\
\hline BIG BEND CC & 0 & 0 & 0 & 1 \\
\hline CHEMEKETA CC & 2 & 0 & 0 & 1 \\
\hline CENTRAL OREGON CC & 0 & 0 & 0 & 1 \\
\hline WHATCOM CC & 1 & 0 & 0 & 1 \\
\hline SO.PUGET SOUND CC & 1 & 0 & 0 & 2 \\
\hline LOWER COLUMBIA CC & 1 & 0 & 0 & 1 \\
\hline WENATCHEE VALLEY CC & 1 & 0 & 0 & 0 \\
\hline SPOKANE CC & 1 & 0 & 0 & 1 \\
\hline COLUMBIA BASIN CC & 1 & 0 & 0 & 1 \\
\hline CLATSOP CC & 0 & 0 & 0 & 1 \\
\hline OREGON COAST CC & 0 & 0 & 0 & 1 \\
\hline BLUE MOUNTAIN CC & 0 & 0 & 0 & 1 \\
\hline
\end{tabular}


NAME OF CC:

\#41

MORE/SAME/LESS

TOTAL

INVOLVEMENT

POINTS

( $M: 2 ; S: 1)$

EDMONDS CC

SHORELINE' CC

MT. HOOD CC

TACOMA CC

SPOKANE FALLS CC

PORTLAND CC

SKAGIT VALLEY CC

SEATTLE NORTH CC

LANE CC

EVERETT CC

CLACKAMAS CC

YAKIMA VALLEY CC

SEATTIE CENTRAL CC

HIGHLINE CC

ROGUE CC

CLARK CC

PIERCE COLLEGE

LINN-BENTON CC

BIG BEND CC

CHEMEKETA CC

CENTRAL OREGON CC

WHATCOM CC

SO.PUGET SOUND CC

LOWER COLUMBIA CC

WENATCHEE VALLEY CC

\section{2}

2

2

2

2

2

2

2

2

2

2

1

2

2

2

2

2

2

2

2

2

2

2

2

2

2

2

1

1
186

175

162

155

145

139

133

128

119

116

115

109

107

99

97

95

95

87

80

72

66

43

39

38

24

20

17 
APPENDIX $\mathrm{F}$

PROTOCOL INSTRUMENT 
INTERVIEW PROTOCOL

1. Can you describe for me the students that attend your college, including International students?

2. Can you describe for me the faculty that teach at your college?

3. Can you describe for me the community in which your college is located?

4. Can you describe for me the structure and organization of your college?

5. Can you describe for me the history of the International Education and Programs of your college?

6. What do you think made a difference in bringing International Education and Programs to your campus?

7. Can you describe for me the funding and staffing for International Education and Programs at your college?

8. Can you describe for me the goals and objectives for International Education and Programs at your college?

9. Can you describe for me the strengths and weaknesses of International Education and Programs at your college?

10. Can you describe for me the future of International Education and Programs at your college? 